\title{
ASSESSMENT OF ASPEN AND NORTHERN HARDWOODS EXTENT IN THIRTY THREE COUNTIES OF UPPER/LOWER MICHIGAN
}

Sara Alian

Michigan Technological University

Follow this and additional works at: https://digitalcommons.mtu.edu/etds

Part of the Forest Sciences Commons

Copyright 2013 Sara Alian

\section{Recommended Citation}

Alian, Sara, "ASSESSMENT OF ASPEN AND NORTHERN HARDWOODS EXTENT IN THIRTY THREE COUNTIES OF UPPER/LOWER MICHIGAN", Master's Thesis, Michigan Technological University, 2013.

https://doi.org/10.37099/mtu.dc.etds/592

Follow this and additional works at: https://digitalcommons.mtu.edu/etds

8 Part of the Forest Sciences Commons 


\title{
ASSESSMENT OF ASPEN AND NORTHERN HARDWOODS EXTENT IN THIRTY THREE COUNTIES OF UPPER/LOWER MICHIGAN
}

By

Sara Alian

\begin{abstract}
A THESIS
Submitted in partial fulfillment of the requirements for the degree of MASTER OF SCIENCE

In Forestry
\end{abstract}

MICHIGAN TECHNOLOGICAL UNIVERSITY

(C) Sara Alian 2013 
This thesis has been approved in partial fulfillment of the requirements for the Degree of MASTER OF SCIENCE in Forestry.

School of Forest Resources and Environmental Science

Thesis Advisor:

Dr. Ann Maclean

Committee Member:

Dr. Robert Froese

Committee Member:

Dr. David Watkins

School Dean:

Dr. Terry Sharik 


\section{Table of Contents}

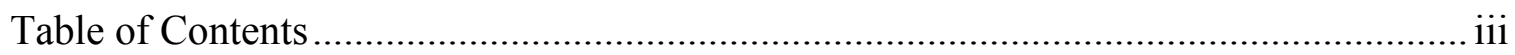

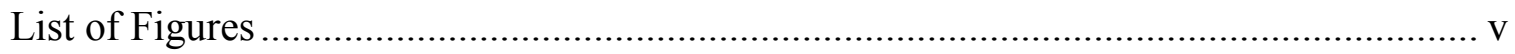

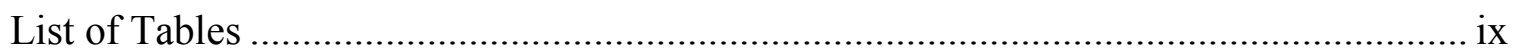

Acknowledgements ...................................................................................................... X

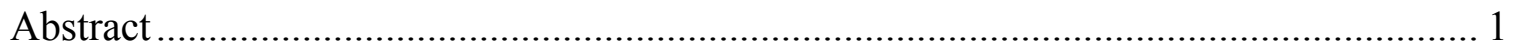

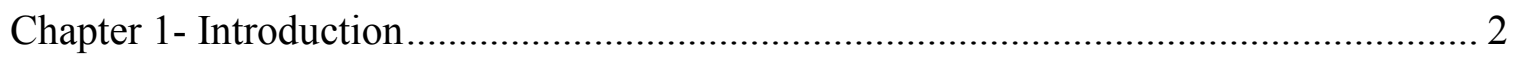

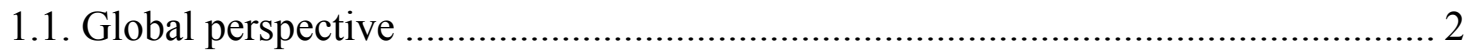

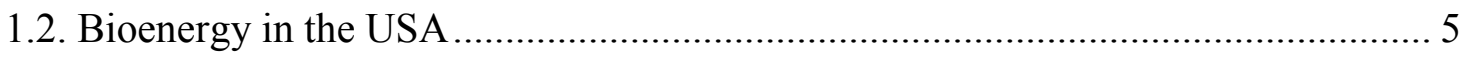

1.3. Woody biomass for bioenergy in Michigan.......................................................... 6

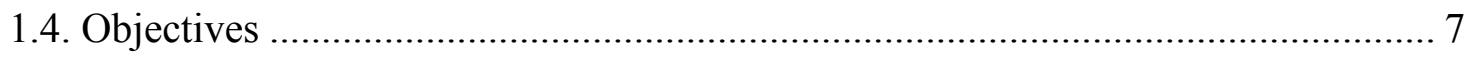

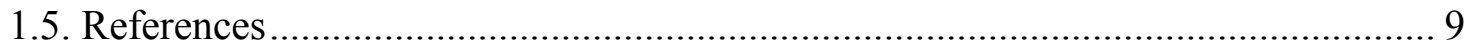

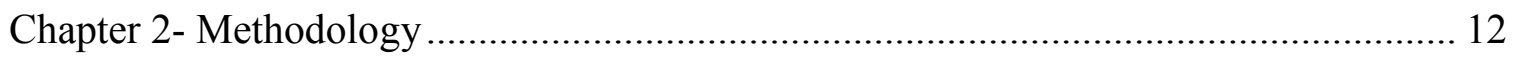

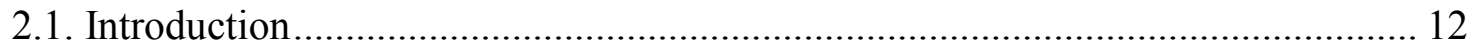

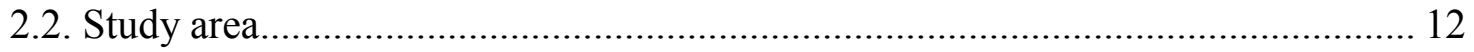

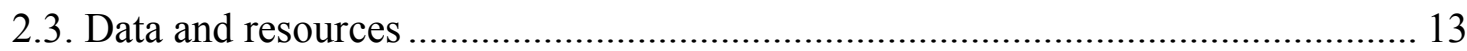

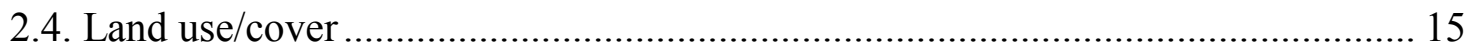

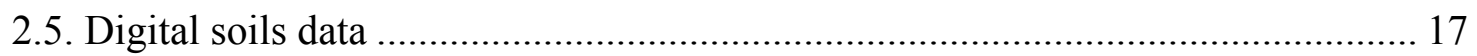


2.6. Road network

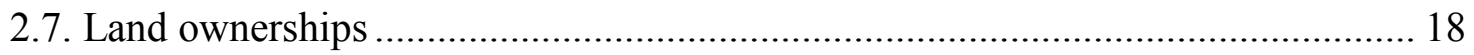

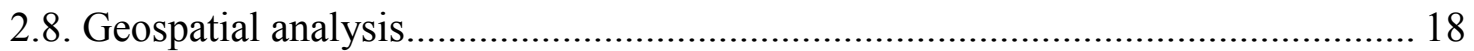

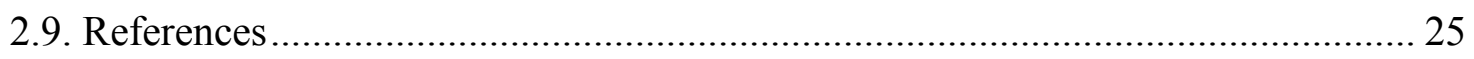

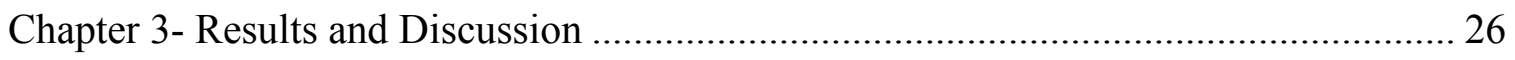

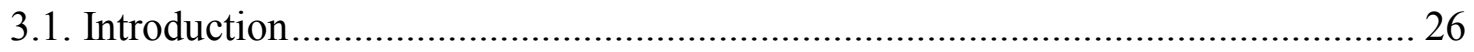

3.2. Aspen and Northern Hardwoods Distribution Circa 2001 .................................. 26

3.3. Current agricultural lands suitable for potential feedstock production................. 29

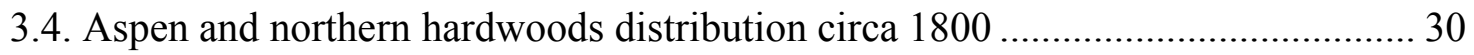

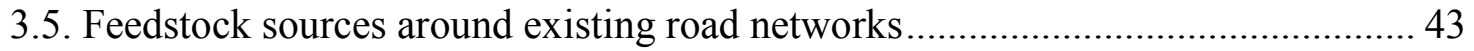

3.6. Potential feedstock source restoration areas ................................................. 48

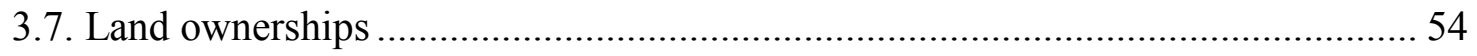

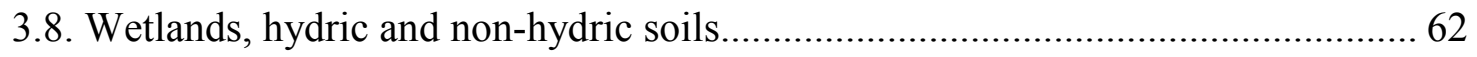

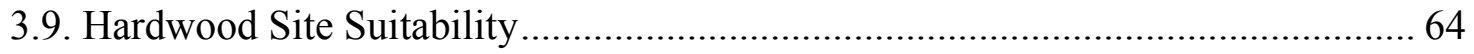

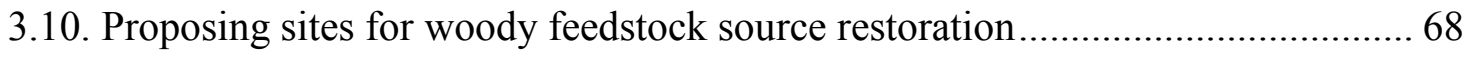

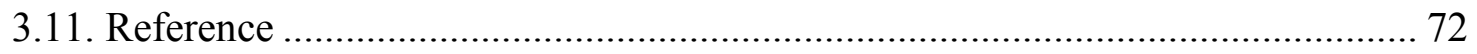

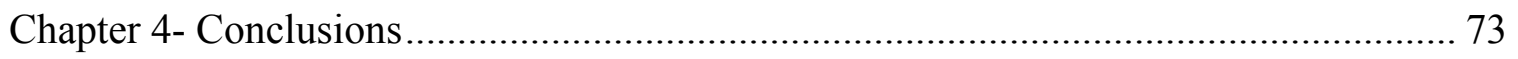

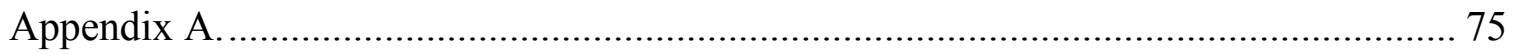




\section{List of Figures}

Figure 1.1. Biofuel production between 2000 and 2010

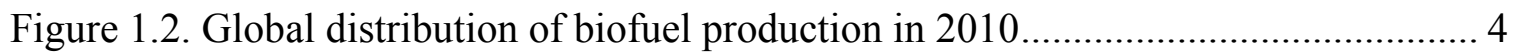

Figure 2.1. Study area in the eastern Upper Peninsula and the northern Lower Peninsula of Michigan, including buffer zones of 50, 100, 150 miles from the Kinross plant ........ 13

Figure 2.2. Pre-European settlement vegetation data extraction process ....................... 19

Figure 2.3. Land use/cover 2001 vegetation data extraction process ............................. 20

Figure 2.4. Present day farmland extraction from CDL 2011 raster ................................ 20

Figure 2.5. Characterization of pre-European settlement land cover change from aspen and northern hardwoods to other land use/cover types 21

Figure 2.6. Flowchart for identifying proximity of pre-European settlement and present day aspen and northern hardwoods to the road network 22

Figure 2.7. Flowchart for identifying potential feedstock restoration areas based on comparison between pre-European settlement and present day vegetation 23

Figure 2.8. Flowchart for identifying potential feedstock restoration areas based on soil characteristics, land accessibility, and comparison between pre-European settlement and present day vegetation 24

Figure 3.1. 2001 Aspen and northern hardwoods stands in the UP and LP study areas... 29

Figure 3.2. Corn and other crops in 2011 31

Figure 3.3. Corn and other crops in 2011. Also, shown are areas of farmland currently underutilized in the LP study area 32

Figure 3.4. Aspen and other crops in 2011 in Benzie County in the LP study area 33 
Figure 3.5. Aspen and other crops in 2011 in Presque Isle County in the LP study area 34

Figure 3.6. Pre-European aspen and northern hardwoods distribution in the UP study are 35

Figure 3.7. Pre-European aspen and northern hardwoods distribution in the LP study area. 36

Figures 3.8. Land use change to aspen and northern hardwoods, and other land use types between pre-European settlement era and circa 2001 in the UP study area 39

Figures 3.9. Land use change to aspen and northern hardwoods, and other land use types between pre-European settlement era and circa 2001 in the LP study area 40

Figure 3.10. Land use changes to other land use types in the UP study area between preEuropean settlement and circa 2001 41

Figure 3.11. Land use changes to other land use types in the LP study area between preEuropean settlement and circa 2001 42

Figure 3.12. Proximity of aspen and northern hardwoods to the road network in the UP and LP in the study area using IFMAP data 45

Figure 3.13. Aspen and northern hardwoods proximity to the road network in the UP study area 46

Figure 3.14. Aspen and northern hardwoods proximity to the road network in the UP study are 47

Figure 3.15. Proximity of Pre-European settlement aspen and northern hardwoods areas to the road network in the UP and LP study area 50

Figure 3.16. Pre-European settlement aspen and northern hardwoods proximity to the road network in the UP study area 52 
Figure 3.17. Pre-European settlement aspen and northern hardwoods proximity to the road network in the LP study area 53

Figure 3.18. Land ownerships in the UP and LP study areas 54

Figure 3.19. Aspen and northern hardwoods extent on federal lands in the UP study area 57

Figure 3.20. Aspen and northern hardwoods extent in federal lands on the LP study area in 2001 58

Figure 3.21. Pre-European aspen and northern hardwoods distributions within current federal and state lands in the UP study area 60

Figure 3.22. Pre-European aspen and northern hardwoods distributions within current federal and state lands in the LP study area 61

Figure 3.23. Aspen and northern hardwoods in hydric and non-hydric soil in the UP study area 63

Figure 3.24. Aspen and northern hardwoods in hydric and non-hydric soil in the LP study area 63

Figure 3.25. Aspen and northern hardwoods association in hydric and non-hydric soils in the study area 64

Figure 3.26. Aspen and northern hardwoods extent on different soil suitability classes for establishing these cover types in the UP study area ..... 66

Figure 3.27. Aspen and northern hardwoods extent on different soil suitability classes for establishing these cover types in the LP study area 66

Figure 3.28. Potential restoration areas in the UP study area based on 1800s and 2001 data 67

Figure 3.29. Potential restoration areas in the LP based on 1800s and 2001 data 67 vii 
Figure 3.30. Proposed sites using the potential sites for feedstock source restoration in the UP

Figure 3.31. Proposed sites using the potential sites for feedstock source restoration in the

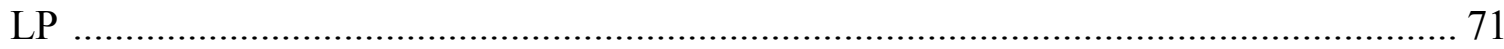




\section{List of Tables}

Table 1.1. Wood-based electric power production facilities in Michigan ...................... 7

Table 2.1. Data inputs and sources

Table 3.1. Aspen and northern hardwoods distribution within buffer zones of 50, 100, and 150 miles from Kinross plant 28

Table 3.3. Land use change from hardwood and aspen to other land uses between circa 1800 and circa 2001

Table 3.4. Incremental aspen and northern hardwoods distribution on hydric and nonhydric soils for different distances from road network in the UP and LP study areas using IFMAP data

Table 3.5. Incremental proximity of pre-European aspen and northern hardwoods to the road network in the UP and LP study areas.

Table 3.6. Non-accessible lands in the study area and the corresponding amount of aspen and northern hardwoods association (circa 2001)

Table 3.7. Incremental aspen and northern hardwoods in the recommended restoration sites in the UP and LP study areas 69

Table A-1. Aspen and northern hardwoods distribution for the counties within the study area 


\section{Acknowledgements}

I appreciate the support I received directly or indirectly from Dr. Margaret Gale, the

former School Dean, Dean Terry Sharik, and Dr. Andrew Storer, as well as the faculty and staff of the School of Forest Resources and Environmental Science. I acknowledge their help and support at different stages of my Master's education at Michigan Technological University. Most importantly, I want to thank my advisor, Dr. Ann Maclean, for trusting a young architect who wanted to learn more about geospatial analysis and the use of geographic information science. I thank her for being super supportive, and for helping me develop my professional skills and knowledge. I would also like to thank my Master's committee members, Dr. Robert Froese and Dr. David Watkins. I appreciate their time and the valuable comments on an earlier version of this thesis.

Furthermore, many thanks to the Canterbury House, a house for everyone, a great place to learn language, culture, and find great friends like Dr. Neely Farren- Eller, Susan Lacasse, Rick Buis, Rebecca Bender and many other great people whom I had a chance to meet there, and become friends with.

I would like to say thank you to Debra and Dennis Kamrad, my rowing coaches, whom I love and respect a lot because of their great, positive impact on my personal life. I want to thank Nancy and Dianne Sprague, very special and wonderful individuals, who shared all their Thanksgiving dinners, New Year's Eves, and other fun moments of their lives with me. I want to say thank you to Drs. Thomas Werner, Alessia Uboni, Anahita Pakzad, Sinan Abood, Julio Rivera, as well as Hasti Asayesh, Riccardo Tortini, Mayra 
Sanchez Gonzalez, and my friends in the Iranian Community, and other great people from around the world who are part of my great memories in the Keweenaw.

My sincere gratitude goes to my parents, Susan Zahiri and Alireza Alian for their love, support, and encouragement. Furthermore, I would like to thank my brother, Sepehr Alian, and all my lovely friends back home whom I have missed a lot.

Finally, I want to thank my great husband, Ali Mirchi, for being there for me anytime I needed his help and support. He is the one who is always by my side, and continues his unconditional love and unlimited support. 


\section{Abstract}

The importance of the United States' wood and wood byproducts as biomass feedstocks is increasing as the concern about security and sustainability of global energy production continues to rise. Thus, second generation woody feedstock sources in Michigan, e.g., hybrid poplar and hybrid willow (Populus spp.), are viewed as a potential source of biomass for the proposed biofuel ethanol production plant in Kinross, MI. It is important to gain an understanding of the spatial distribution of current feedstock sources, harvesting accessibility via the transportation infrastructure and land ownerships in order to ensure long-term feedstock extent. This research provides insights into the current extent of aspen and northern hardwoods, and an assessment of potential for expanding the area of these feedstock sources based on pre-European settlement conditions. A geographic information system (GIS) was developed to compile available geospatial data for 33 counties located within 150 miles of the Kinross facility. These include present day and pre-European settlement land use/cover, soils, road infrastructure, and land ownerships. The results suggest that a significant amount of northern hardwoods has been converted to other land use/cover types since European settlement, and the "scattering" of aspen stands has increased. Furthermore, a significant amount of woody biomass is available in close proximity to the existing road network, which can be effectively utilized as feedstock. Potential aspen and northern hardwoods restoration areas are identified in the vicinity of road networks which can be used for future woody feedstock production. 


\section{Chapter 1- Introduction}

\subsection{Global perspective}

Producing sufficient energy and transitioning to non-fossil fuel energy sources is a global issue driven by concern about energy security and climate change. Current global energy consumption is dominated by fossil fuels (e.g., oil, gas, and coal). Nonrenewable energy resources are believed to be limited (WEC, 2010), and some predict world oil production will peak around 2030 (Sorrell et al., 2010; Bentley et al., 2009). Hence, new policies and incentives to develop sustainable energy sources and increase their utilization are under development (Scharlemann et al., 2009).

Interestingly, high oil production forecasts by International Energy Agency (IEA), the United States' Energy Information Administration (EIA), and Organization of Petroleum Exporting Countries (OPEC) state that peak oil production is not a serious threat. However, energy security is increasingly an overarching concern since major oil production occurs in many countries experiencing political instability. In order to improve energy security the world needs to spend time and financial resources to diversify the global energy portfolio. However, global energy transition will be challenging since industrial and economic processes depend highly on fossil fuels and their byproducts.

In addition, developing renewable energy resources is important due to global climate change. There is extensive evidence that the world is becoming warmer (IPCC, 2001). Since fossil fuels have large carbon footprints, it is critical for global energy 
policies to focus on lower carbon footprint energy sources such as solar, wind, hydropower and biofuels.

Thorough investigations into the potential of replacing fossil fuels with biofuels are needed before substantial changes in energy policies can occur (Tilman et al., 2009). Biofuels are viewed by many as a viable renewable energy source which can be used in the primary energy mix, particularly in the transportation fuel and electricity generation sectors (McKendry, 2002; Hill, 2006).

The use of transportation fuels derived from biomass has been projected to increase by more than $400 \%$ by 2035 (IEA WEO, 2010). Energy production from biofuels doubled between 2000 and 2005 and further increased up to 6 times between 2005 and 2010 (Figure 1.1). North, South and Central America are the major producers of biofuel (Figure 1.2). Proponents of biofuels attribute a number of benefits to this energy source including low greenhouse gas (GHG) emissions, improving local energy security and trade balances, and creating opportunities for socio-economic development in rural areas (WEC, 2010). One key factor constraining the use of biomass for energy production is resource availability (WEC, 2010). Furthermore, the choice of feedstock species grown and harvested will determine biomass yield, which is critical for the long term viability of production facilities (Solomon et al., 2007). As a result of these concerns, local and regional woody feedstock availability, both current and future, needs to be better understood before biofuel's share in the energy portfolio can be a projected realistically. 


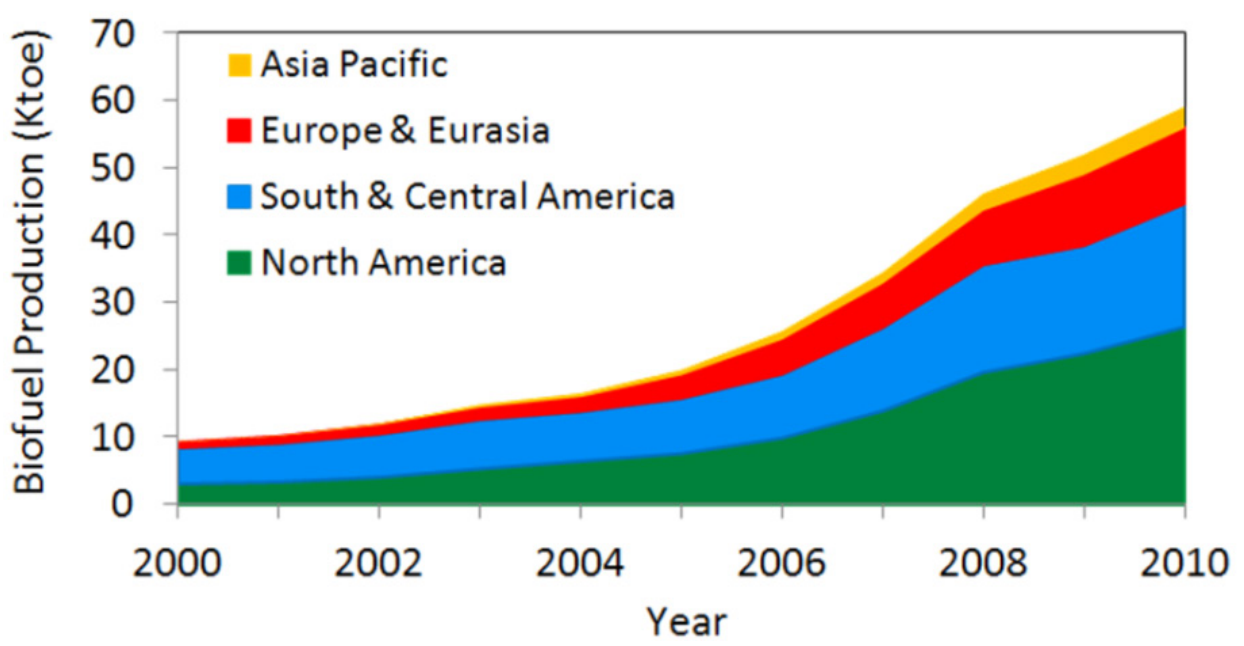

Figure 1.1. Biofuel production between 2000 and 2010 (Source: BP, 2011).

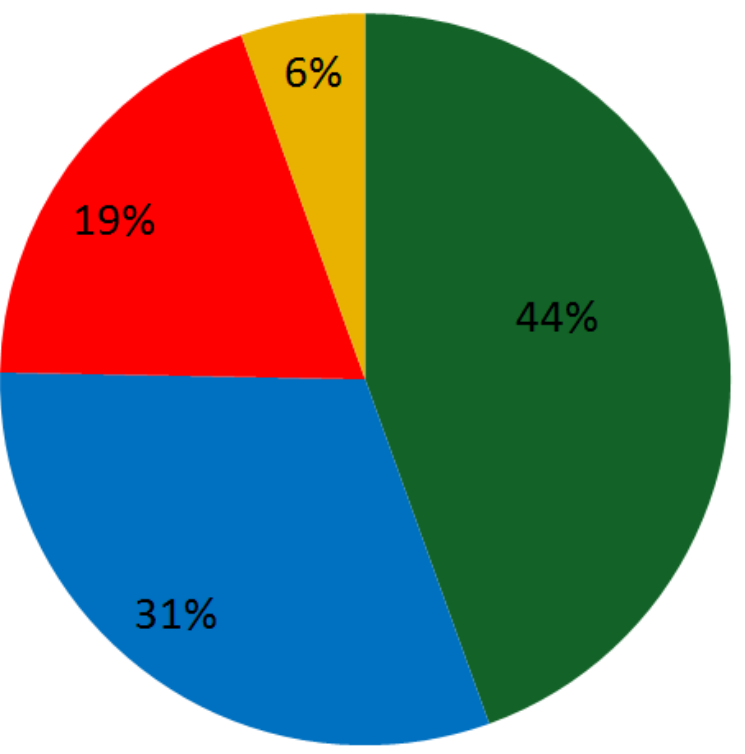

north America

- South \& Central America

- Europe \& Eurasia

Asia Pacific

Figure 1.2. Global distribution of biofuel production in 2010 (Source: BP, 2011). 


\subsection{Bioenergy in the USA}

From a historical standpoint, most countries relied heavily on woody biomass to meet their energy needs. In the United States in 1880, almost $60 \%$ of energy came from wood. However by the mid-19th century, fossil fuels replaced woody biomass due to their high energy intensity, ease of transportation and use (Simpkins, 2006). Recent biofuel research findings are setting the stage for reintroduction of woody biomass as a key energy source. For example, Bartle and Abadi (2010) demonstrated the superiority of second generation feedstocks (woody crops) to first generation feedstocks (sugar, corn stover, starch and vegetable oils) by illustrating their lower effective cost, sustainability and environmental impacts. Furthermore, first generation biofuel feedstocks are also used as food crops, creating a competition of uses and driving up food prices (Tilman, 2009). Wood chips are likely better resources of ethanol as compared with other green resources such as corn, sugarcane, and soy because of their lower GHG footprint (Scharlemann et al., 2008).

Wood and wood byproducts are one of the important biomass feedstocks in the United States. Over the last 35 years, major changes in energy policy and economy have led the energy market to use wood energy as a competitor with traditional coal-fired and natural gas electricity generation. Zhang et al. (2010) applied a life cycle analysis approach to compare carbon emission of wood pellet firing and coal generating stations in Ontario, Canada. Their research suggests that carbon emissions of coal generating stations are more than ten times greater than that of wood pellet firing plants. Froese et al. (2010) demonstrated the potential for the use of forestry residuals for reducing carbon emissions from power generation in the US Great Lakes States. Mitchell et al. (2012) 
argue that harvesting of forests for the purpose of biofuel production may result in a net carbon debt because it will take a shorter time for unharvested forests to store the amount of carbon that would be saved if they were harvested for use for biofuel production. In any case, large scale net carbon emission reductions for generating power from wood residues may be achievable in the long run rather than short term (Mckechnie et al., 2011).

\subsection{Woody biomass for bioenergy in Michigan}

In Michigan's Upper Peninsula and northern Lower Peninsula there is considerable potential for producing biofuel from feedstock sources such as aspen, northern hardwood species, hybrid poplar, and hybrid willow (Populus spp.) since the current rate of growth exceeds the amount harvested (Leefers et al., 2010). Several facilities in Michigan produce electric power from wood fuel (Johnson et al., 2011). Table 1.1 provides information about the location of some of these facilities along with their electric production capacity and wood consumption in Michigan.

Frontier Renewable Resources and Valero Energy Corporation have a joint venture and are constructing a commercial-scale cellulosic ethanol facility in Kinross, Michigan. The facility will convert woody feedstock to ethanol with an initial capacity of 20 million gallons of ethanol per year (Leefers et al., 2010). Historically, this area has been a major producer of pulpwood. During the period of 2003 to 2007, more than $50 \%$ of pulpwood production in Michigan took place in the Kinross supply region (Leefers et al., 2010). The pulpwood production trend for the Kinross region, as well as for the state of Michigan has been declining (Leefers et al., 2010). The proposed biofuel production 
facility may increase the harvest of aspen and northern hardwoods in the Kinross supply region. Assessment of aspen and northern hardwoods distribution in this region provides insights for sustainable supply of woody feedstock to the biofuel production facility.

Table 1.1. Wood-based electric power production facilities in Michigan (Johnson et al., 2011).

\begin{tabular}{lccc}
\hline Plant & Location & $\begin{array}{c}\text { Production } \\
\text { Capacity (kW) }\end{array}$ & $\begin{array}{c}\text { Wood Consumption } \\
\text { (tons/yr) }\end{array}$ \\
\hline Hillman Power Co. & Hillman & 20,000 & 230,000 \\
Viking Energy/ Lincoln & Lincoln & 18,000 & 150,000 \\
Cadillac Renewable Energy & Cadillac & 39,600 & 375,000 \\
Viking Energy/ McBain & McBain & 18,000 & 150,000 \\
Genesee Power Station & Flint & 39,500 & 300,000 \\
Grayling Generating Station & Grayling & 38,000 & $250,000-300,000$ \\
L'Anse Warden Electric & L'Anse & 20,000 & 65,000 \\
Company, LLC & & & \\
\hline
\end{tabular}

\subsection{Objectives}

It is critical to gain an understanding of the spatial distribution of the current feedstock sources in terms of volume, accessibility for harvest when considering the transportation infrastructure and land ownerships, distance from the processing facility, and changes in land cover patterns utilizing GIS. Therefore, the objectives of this research are as follows: 
- Determine the spatial distribution of the aspen and northern hardwoods forests and their proximity to appropriate transportation networks;

- Compare current distributions to historic distributions to gain insight where potential forest types could be converted to pre-European settlement conditions in order to increase long term feedstock extent to the Kinross facility;

- Identify existing agricultural or underproductive areas which could be converted to feedstock plantations; and

- Identify potential sites where aspen and northern hardwoods forests could be restored to the pre-European condition in order to increase biofuel feedstock production potential.

ArcMap 10.1 is used to create a geographic information system (GIS) to analyze the spatial distribution of aspen and northern hardwoods in 33 Michigan counties within 150 miles of the Kinross facility. Also, the historic and current distribution of the aspen and northern hardwoods and the land use change characterized. Chapter Two details data sources and methods applied for identifying feedstock extent and restoration potential. Chapter Three provides results and discussion, followed by conclusions in Chapter Four. 


\subsection{References}

Bartle. J.R. and A. Abadi. 2010. Toward sustainable production of second generation bioenergy feedstocks, Energy Fuels, 24 (1): 2-9.

Bentley. R.W. R.G. Miller. W. Wheeler. G. Boyle. 2009. Comparison of global oil supply forecasts. UKERC Review of Evidence on Global Oil Depletion: Technical Report 7, UK Energy Research Centre: London.

British Petroleum (BP). BP Statistical Review of World Energy. 2011. BP: London, UK, 2011. <http://www.bp.com/sectionbodycopy.do?categoryId=7500\&contentId $=7068481>($ accessed on 25 November 2012).

Froese R.E. D.R. Shonnard. C.A. Miller. K.P. Koers. D.M. Johnson. 2012. An evaluation of greenhouse gas mitigation options for coal-fired power plants in the US Great Lakes States, Biomass \& Bioenergy, 34(3):251-262.

Hill .J. E. Nelson. D. Tilman. S. Polasky. D. Tiffany. 2006. Environmental, economic, and energetic costs and benefits of biodiesel and ethanol biofuels, Proceedings of the National Academy of Sciences USA, 103(30):11206-11210.

IEA. World Energy Outlook. 2010. International Energy Agency. 2010:731.P10. $<$ http://www.worldenergyoutlook.org/media/weowebsite/2010/WEO2010_es_eng lish.pdf $>$ (accessed on 19 January 2013).

Intergovernmental Panel on Climate Change (IPCC). 2001. Climate change 2001: scientific basis. In: Metz. B. et al. (Eds.) Contribution of working group III to the third assessment report of the Intergovernmental Panel on Climate Change. Published for the Intergovernmental Panel on Climate Change. Cambridge University Press, Cambridge, UK and New York, NY, USA. 
Johnson. D. M. M. A. Johnson. F. Zhang. 2011. Final report for Forestry Biofuel Statewide Collaboration Center (FBSCC) - subtask b4: extended supply chain model and assess economic business viability project. Sustainable Futures Institute, Michigan Technological University. $<$ http://www.michiganforestbiofuels.org/sites/default/files/FBSCC\%20Task\%20B 4\%20Final\%20Report.pdf $>$ (accessed on 10 June 2013).

Leefers. L.A. and J.M. Vasievich. 2010. Timber Resources and Factors Affecting Timber Availability and Sustainability for Kinross, Michigan. Report prepared for the Feedstock Supply Chain Center of Energy Excellence. Kinross Project 2 Report, Version 2.0., East Lansing, MI: Michigan State University, Department of Forestry. 55 p.

Mckechnie. J. S. Colombo. J. Chen. W. Mabee. H. Maclean. 2011. Forest bioenergy or forest carbon? Assessing trade-offs in greenhouse gas mitigation with woodbased fuels. Environmental Science \& Technology, 45: 789-795.

McKendry. P. 2002. Energy production from biomass (part 2): Conversion technologies. Bioresource Technology, 83(1): 47-54.

Mitchell SR, M.E. Harmon. K.E.B. O'Connell. 2012. Carbon debt and carbon sequestration parity in forest bioenergy production. Global change biology. Bioenergy, 4: 818-827.

Scharlemann. J.P.W. W.F. Laurance. 2008. How Green Are Biofuels?, Science, 319(5859): 43-44.

Simpkins. D. N. Allard. J. Patrick. 2006. Clean energy from wood residues in Michigan, Michigan Biomass Energy Program, Department of Labor \& Economic Growth, 
Lansing, MI. <http://www.michigan.gov/documents/wood_energy_in_michigan-final1_169999_7.pdf> (accessed on 19 January 2013).

Solomon. B.D. J.R. Barnes. K.E. Halvorsen. 2007. Grain and cellulosic ethanol: history, economics, and energy policy, Biomass Bioenergy, 31(6): 416-425.

Sorrell. S. R. Miller. R. Bentley. J. Speirs. 2010. Oil futures: A comparison of global supply forecasts. Energy Policy, 38(9): 4990-5003.

Tilman. D. R. Socolow. J.A. Foley. J. Hill. E. Larson. L. Lynd. S. Pacala. J. Reilly. T. Searchinger. C. Somerville. R. Williams. 2009. Beneficial biofuels - the food, energy, and environment trilemma, Science, 325(5938): 270- 271.

World Energy Council (WEC) 2010. 2010. Survey of Energy Resources; WEC: London, UK. <http://www.worldenergy.org/publications/3040.asp $>$ (accessed on 5 September 2011).

Zhang. Y. J. McKechnie. D. Cormier. R. Lyng. W. Mabee. A. Ogino. H.L. MacLean. 2010. Life cycle emissions and cost of producing electricity from coal, natural gas, and wood pellets in Ontario, Canada. Environmental Science and Technology., 44, 538-544; DOI:10.1021/es902555a. 


\section{Chapter 2- Methodology}

\subsection{Introduction}

This chapter presents the materials and methods used in this study. A description of the study area and the spatial analysis are given. A number of state and federal agencies produce and maintain geospatial information, facilitating the characterization of feedstock forests based on specified criteria such as soil type and proximity to road networks. Various data and the sources from which they were obtained are provided. These include pre-European and present-day land use/land cover, political boundaries, hydrography, transportation network (specifically roads), soils, and land ownerships. A geodatabase was developed to compile the data, and ArcMap 10.1 was used to complete the geospatial processing.

\subsection{Study area}

The study area is the eastern half of Michigan's Upper Peninsula (UP) and the northern half of the Lower Peninsula (LP). This area is centered on the Frontier Renewable Resources Commercial-Scale Hardwood Cellulosic Ethanol Facility in Kinross, MI, and the facility's long term need for feedstock. The study area includes all or portions of 33 counties within 150 miles from ethanol facility (Figure 2.1). 


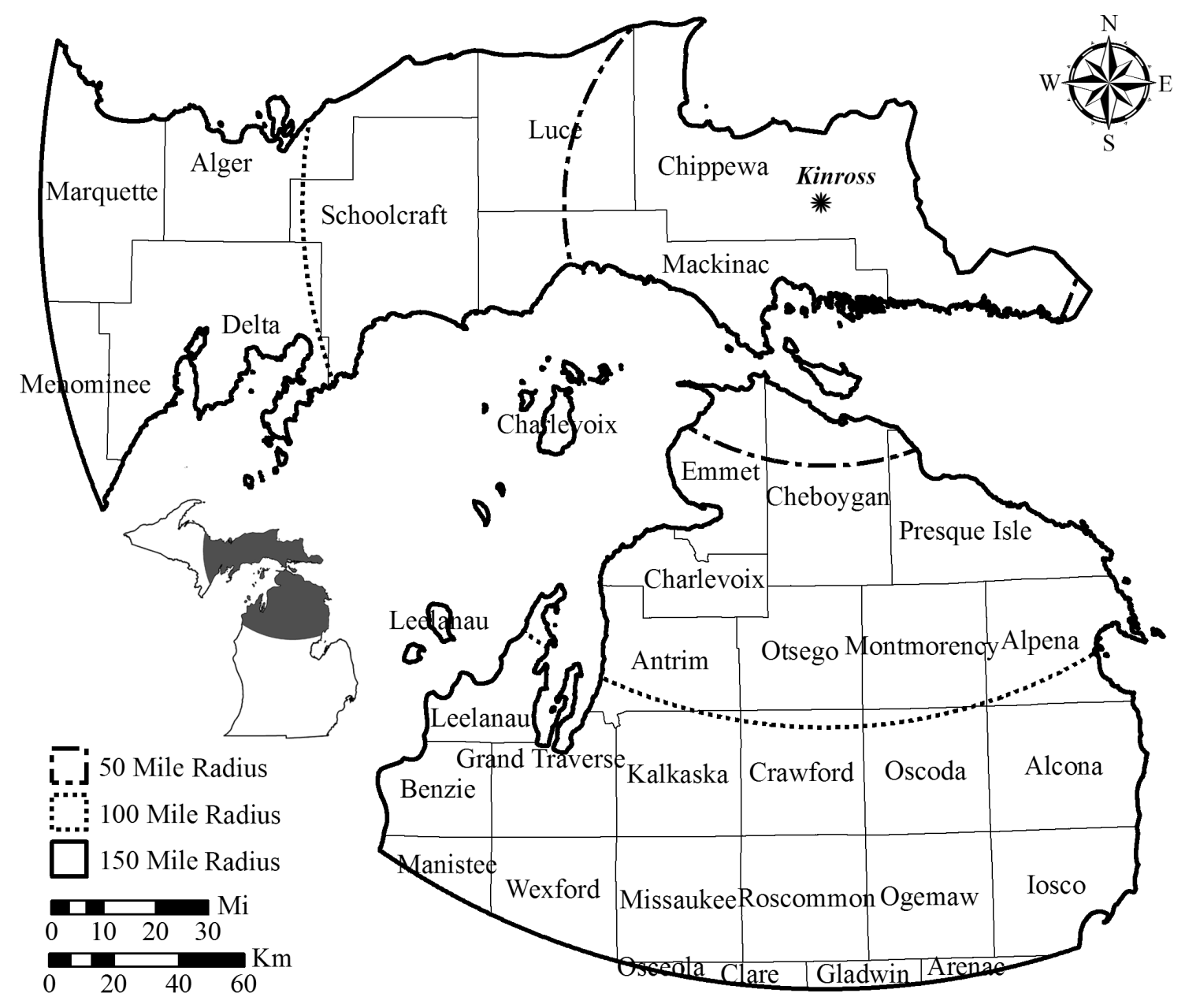

Figure 2.1. Study area in the eastern Upper Peninsula and the northern Lower Peninsula of Michigan, including buffer zones of 50, 100, 150 miles from the Kinross plant (Source: Michigan Geographic Data Library).

\subsection{Data and resources}

The requisite digital data for the analysis are available from various governmental and geospatial clearing houses (Table 2.1). A description of the data is provided below. 
Table 2.1. Data inputs and sources.

\begin{tabular}{|c|c|c|}
\hline Data Type & Source & Date \\
\hline Land cover (IFMAP) & $\begin{array}{l}\text { Michigan Geographic Data Library } \\
\text { http://www.michigan.gov/cgi/ }\end{array}$ & 2001 \\
\hline Crop data layer & $\begin{array}{l}\text { National Agricultural Statistics Service } \\
\text { http://www.nass.usda.gov/research/ } \\
\text { Cropland/SARS1a.htm }\end{array}$ & 2011 \\
\hline Land cover circa 1800 & $\begin{array}{l}\text { Michigan Geographic Data Library } \\
\text { www.mcgi.state.mi.us/mgdl }\end{array}$ & 1978 \\
\hline Digital soil dataset & $\begin{array}{l}\text { Natural Resources Conservation Service } \\
\text { (NRCS) } \\
\text { www.nrcs.usda.gov/ }\end{array}$ & 2011 \\
\hline Wetlands & $\begin{array}{l}\text { The National Wetlands Inventory (NWI) } \\
\text { www.fws.gov/nwi/ }\end{array}$ & 2007 \\
\hline Hydrography/ & $\begin{array}{l}\text { Michigan Geographic Data Library } \\
\text { www.mcgi.state.mi.us/mgdl }\end{array}$ & 2011 \\
\hline $\begin{array}{l}\text { Federal/Native } \\
\text { American ownership }\end{array}$ & Indian land www.nationalatlas.gov & 2005 \\
\hline State land & $\begin{array}{l}\text { Michigan Geographic Data Library } \\
\text { www.mcgi.state.mi.us/mgdl }\end{array}$ & 2001 \\
\hline $\begin{array}{l}\text { County geographic } \\
\text { extent }\end{array}$ & $\begin{array}{l}\text { Michigan Geographic Data Library } \\
\text { http://www.michigan.gov/cgi/ }\end{array}$ & 2011 \\
\hline
\end{tabular}




\subsection{Land use/cover}

Four sources of land use/cover data are utilized in this study, including the Integrated Forest Monitoring, Assessment and Prescription (IFMAP) land use/land cover data from 2001, the Crop Data Layer (CDL) from 2011, pre-European land cover circa 1800 developed by the Michigan Natural Features Inventory, and the National Wetlands Inventory (NWI). IFMAP was developed by the Michigan Department of Natural Resources (MDNR) and provides land use/cover information in a raster format with a 30 $\mathrm{m}$ spatial resolution. IFMAP includes 32 land cover classes in a hierarchical classification scheme (MDNR, 2003), providing present-day northern hardwoods association, aspen association, and other land uses. It is recognized that these data are becoming outdated. However, IFMAP is the only land use/cover dataset for Michigan which separates aspen from northern hardwoods; hence its utilization in the research.

The crop land data layer (CDL) 2011 is a product of the United States Department of Agriculture's (USDA) National Agricultural Statistics Service (NASS). The dataset provides a geo-referenced raster file with a $30 \mathrm{~m}$ spatial resolution, and contains cropspecific land cover information. Satellite imagery acquired during the growing season from a variety of sources is used to produce the dataset (USDA NASS, 2011). The CDL is produced to provide a detailed classification of agricultural lands identifying the spatial extent of production of various crop types. From this dataset, various corn classes (feed, pop, ornamental and sweet) which are suitable for potential conversion to hybrid popular are identified. Most of the fields are located in the southern portion of the LP study area. 
The pre-European settlement dataset provides a basis to characterize land use change between pre-European settlement and current conditions. The Public Land Survey (PLS) conducted by General Land Office (GLO) between 1816 and 1856 provides information about pre-European settlement land cover. Information collected by land surveyors about land cover and other landscape features was interpreted by the Michigan Natural Features Inventory from the original PLS surveyor's notes and a land cover map interpolated. Snetsinger and Ventura (n.d.) investigated the effects of scale on land cover measurements by altering the resolution of present day Landsat based current land cover data set for the state of Wisconsin from $30 \mathrm{~m}$ x $30 \mathrm{~m}$ to $805 \mathrm{~m}$ x $805 \mathrm{~m}(1 / 2$ mile $\times 1 / 2$ mile). They found that the use of coarser resolution had minimal impact on land cover measurements compared with a case where pre-European data set was compared with $30 \mathrm{~m} \times 30 \mathrm{~m}$ present day land cover. However, caution should be practiced when comparing pre-European settlement and present day land cover data because of possible counter-intuitive trends of land cover change that cannot be explained. One example is the large increase (from $1 \%$ to $9 \%$ ) in the extent of wetlands between pre-European settlement and now in the states of Minnesota and Wisconsin (Snetsinger and Ventura, n.d.).

The National Wetlands Inventory (NWI) is produced by the United States Fish and Wildlife Service (FWS) for mapping the approximate location, type, and areal extent of wetlands and other surface waters. The NWI and associated mapping has been completed utilizing satellite and aerial imagery, topographic information and soils data. Wetlands are typically being managed for conservation and restoration projects, which limits their potential for biofuel feedstock production. 


\subsection{Digital soils data}

Digital soils data are available through Soil Data Mart (http://soildatamart.nrcs.usda.gov/), and is produced by the USDA Natural Resources Conservation Service (NRCS). This dataset provides detailed geo-referenced data by county that have been produced via digitization of remotely sensed imagery incorporated with field data. Soils are grouped into two broad categories: hydric and non-hydric. These are based on drainage condition information provided by the associated components, component existing plants (coeplants), component crop yield (cocropyld), component forest productivity (coforprod), and map unit tables. NRCS defines hydric soils as "those that are sufficiently wet in the upper part to develop anaerobic conditions during the growing season." Aspen grows best in deep, well drained soils (Graham et al., 1963); whereas hydric soils characterizing very wet conditions are moderately suitable for aspen production (Gustafson et al., 2003).

\subsection{Road network}

A geo-referenced road network is available from the Michigan Geospatial Data Library. Primary and secondary roads were selected to quantify the proximity of aspen and northern hardwoods forests to the transportation network. This is done by creating incremental buffers ranging from $1 / 4$ mile up to 5 miles and examining the change in the area of the forests with distance from the road network. Primary roads are "generally divided, limited-access highways within the interstate highway system or under State management, and are distinguished by the presence of interchanges. Secondary roads are 
main arteries, usually in the U.S. Highway, State Highway, and/or County Highway system" (US DOC, 2013).

\subsection{Land ownerships}

The United States National Atlas provides Federal and Native American ownership boundaries. State land boundaries are available from the MDNR. These ownerships are utilized to identify land restricted for expansion of woody feedstock sources. State and national parks, wildlife refuges, military installations and Native American lands cannot be designated for production of aspen and hardwood forests and are excluded from the analyses.

\subsection{Geospatial analysis}

ArcMap 10.1 is used to extract spatial data for woody biomass sources. Three buffer zones of 50,100,150 miles from the Kinross plant are used to characterize extent of aspen and northern hardwoods (Figure 2.1). Geospatial processing of pre-European vegetation (circa 1800), as the native vegetation type data, is performed to determine the historic extent of aspen and northern hardwoods in the study area.

Michigan GeoRef was used as the projected coordinate system for the geospatial processing in order to project the geospatial data layers using a single zone. IFMAP geospatial data available for 2001 are used to identify current extent of aspen and northern hardwoods. The two datasets are compared to identify land use change over time. This comparison is important in that it helps identify places where native aspen and northern hardwoods forests have been converted to other land use types (e.g., marginalized agricultural land), which can be used as a reference for restoration planning. 
The areas where changes have occurred are identified, and the type of change determined. Finally, the proximity of aspen and northern hardwoods feedstocks to the transportation network and their location on hydric (wet) and non-hydric soils is analyzed.

The circa 1800 land use/cover layer contains information about the vegetation types from the pre-European settlement era. The data are available by county and are merged to create a seamless polygon for the study area. An attribute field was added to the merged layer to classify the vegetation types into aspen, northern hardwoods, and "other" vegetation types. Finally, the vegetation classes were dissolved to aggregate the vegetation types. The workflow is shown in the Figure 2.2. A similar approach was used to extract present day distribution of aspen and northern hardwoods from IFMAP 2001, as well as farmlands from the CDL 2011 (Figures 2.3 and 2.4).

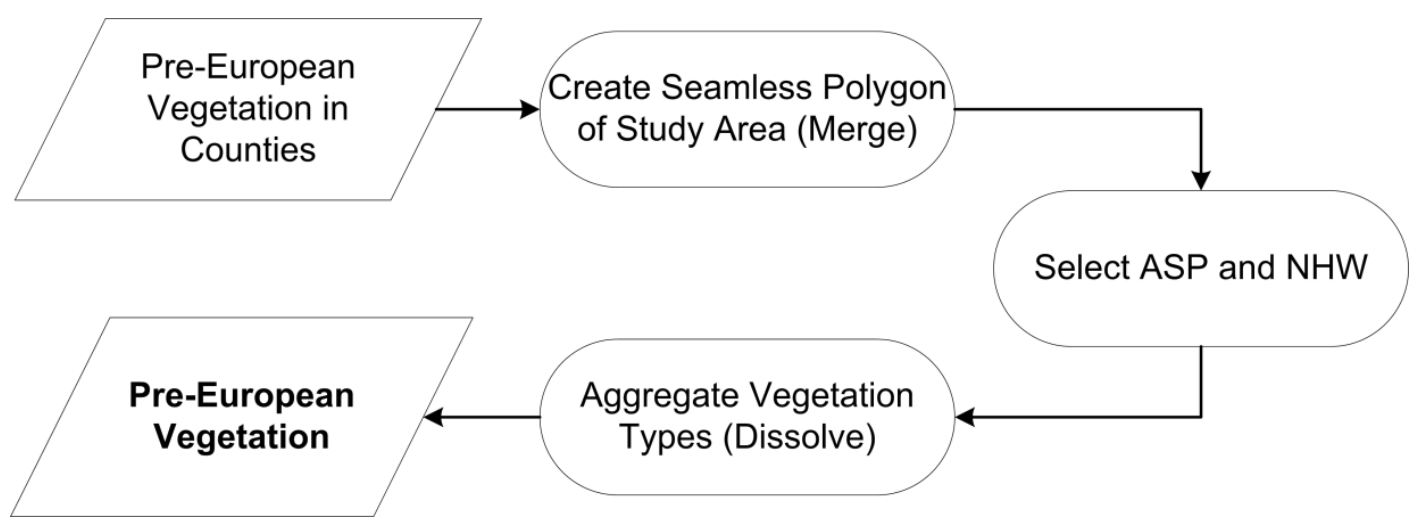

Figure 2.2. Pre-European settlement vegetation data extraction process.

Polygons allow for explicit representation of geospatial features. By contrast, raster files provide an implicit representation of features, which is limited by raster pixel size 
(e.g., 30x30 meters). For these reasons, the IFMAP and CDL raster files were converted to polygons.

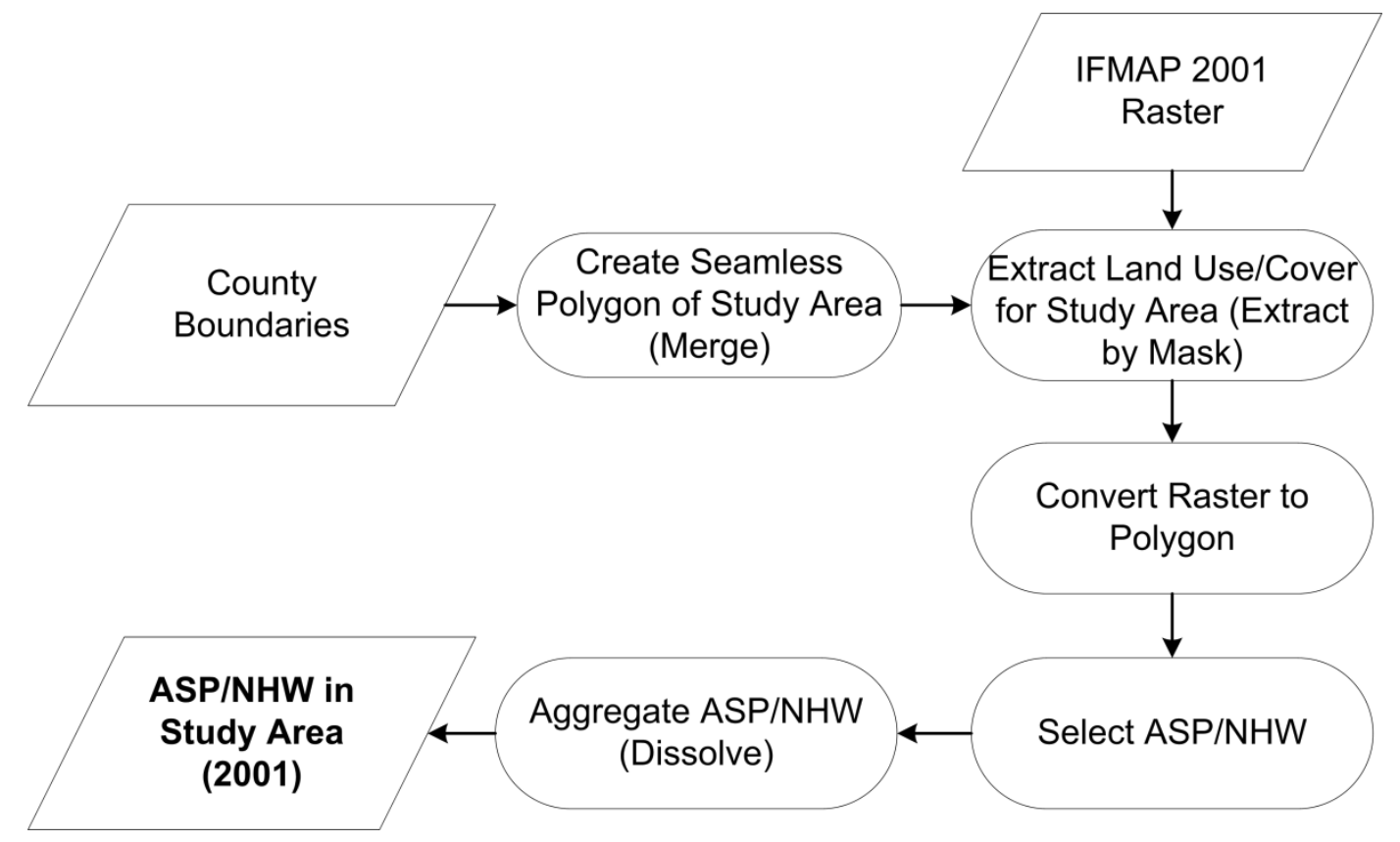

Figure 2.3. Land use/cover 2001 vegetation data extraction process.

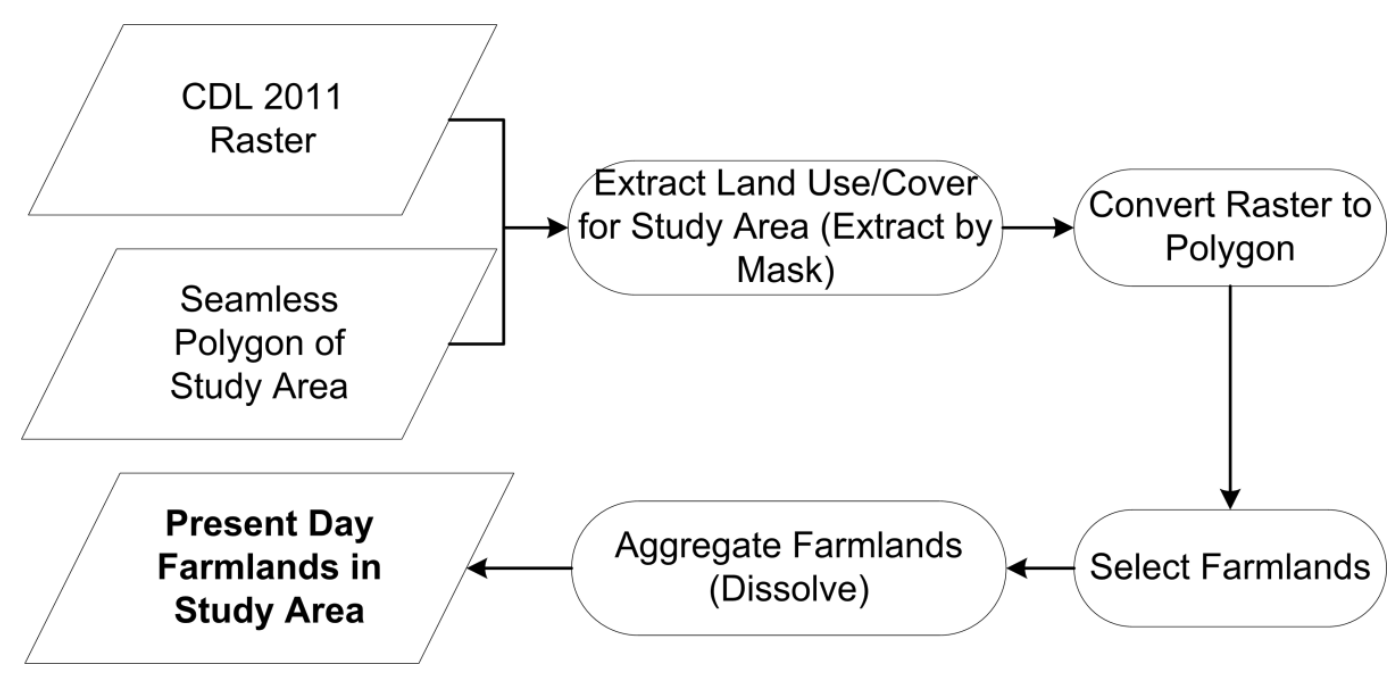

Figure 2.4. Present day farmland extraction from CDL 2011 raster. 
Figure 2.5 illustrates the procedure for determining change from pre-European settlement aspen and northern hardwoods to modern day land use/cover types. First, common aspen and northern hardwoods areas between pre-European settlement and present day land use/cover are erased because these are areas essentially unchanged. Second, present day land use/cover polygons within the remaining pre-European settlement aspen and northern hardwoods are extracted. These areas were classified into agricultural land, forestland, barren, urban and built-up, wetland, and rangeland.

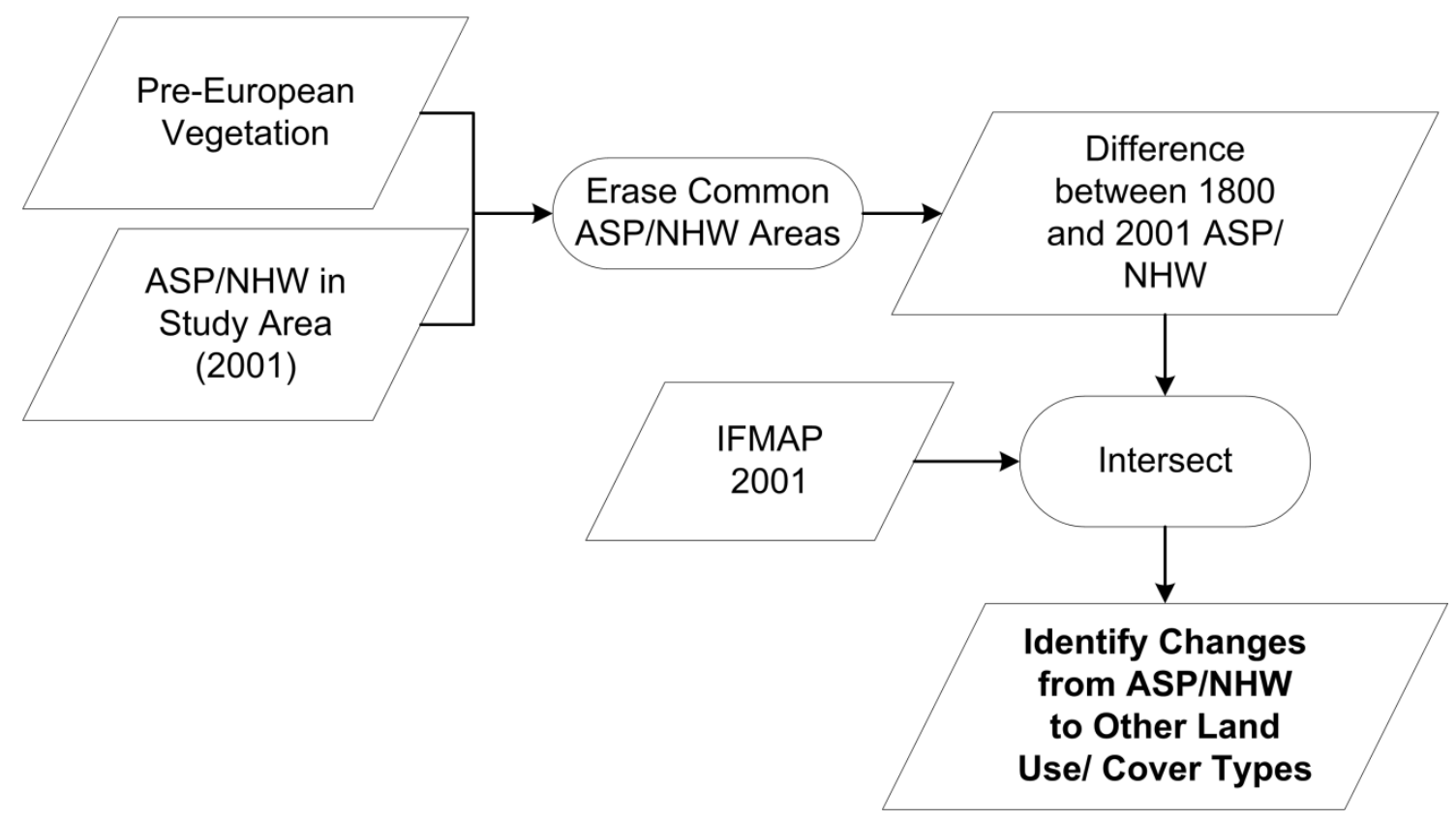

Figure 2.5. Characterization of pre-European settlement land cover change from aspen and northern hardwoods to other land use/cover types. 
Present day aspen and northern hardwoods proximity to primary and secondary roads are characterized by creating incremental width buffers around the road network. The procedure is repeated using pre-European settlement vegetation as a first step for identifying potential feedstock source restoration areas (Figure 2.6). In the next step, areas that were covered with aspen and northern hardwoods in the pre-European era but have changed to other land use/cover types are identified (Figure 2.7).

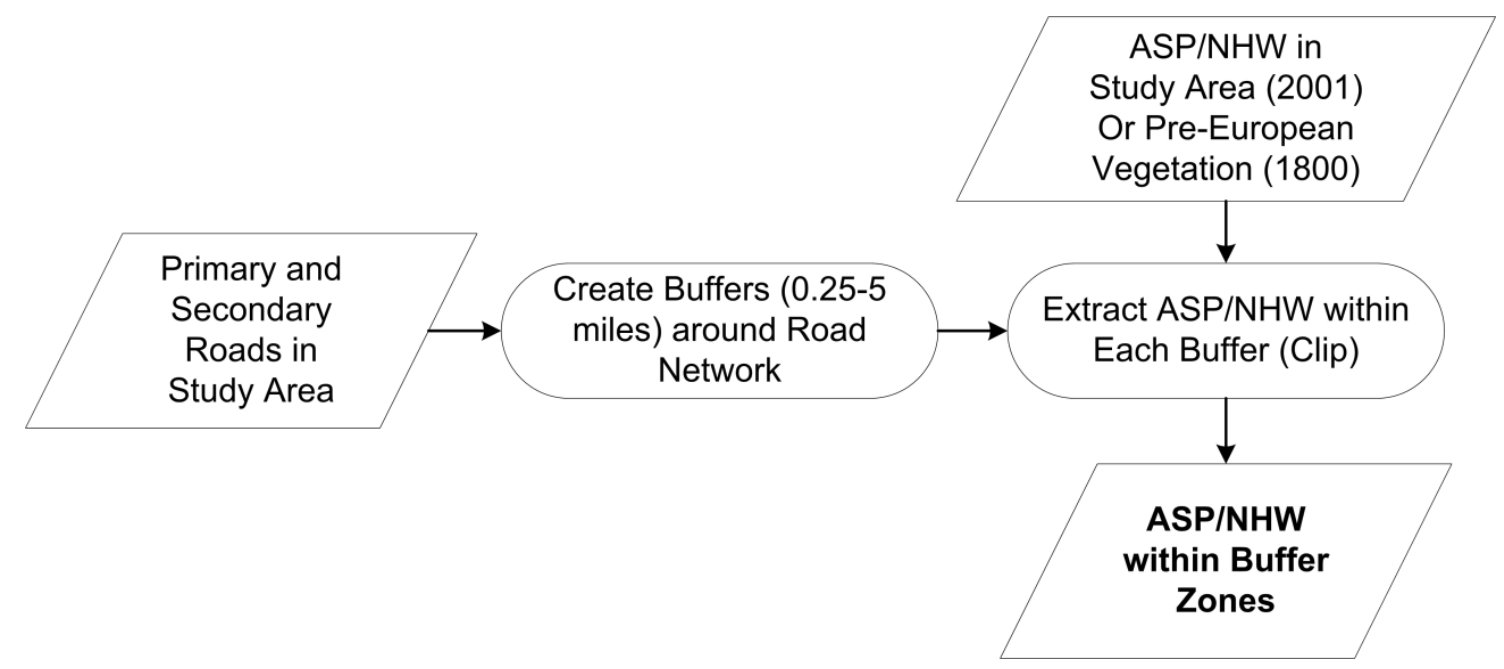

Figure 2.6. Flowchart for identifying proximity of pre-European settlement and present day aspen and northern hardwoods to the road network. 


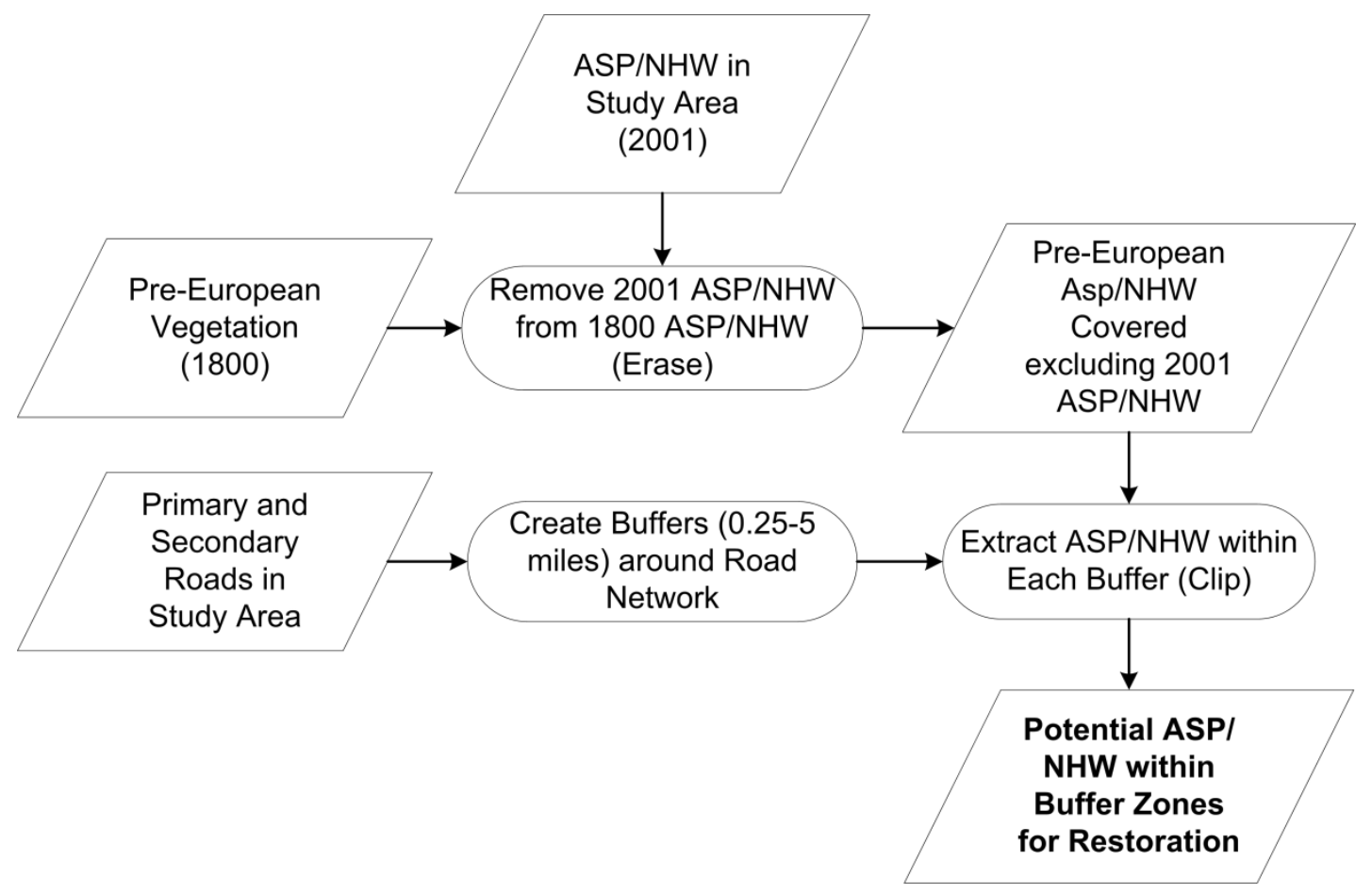

Figure 2.7. Flowchart for identifying potential feedstock restoration areas based on comparison between pre-European settlement and present day vegetation.

The last step in finding suitable areas for potential feedstock sites is to characterize soil characteristics, as well as determine if the land is accessible for restoration. Figure 2.8 shows the procedure for identifying areas with suitable soils (e.g., good and fair) with different moisture content (i.e., hydric and non-hydric). A seamless polygon of the soil data are created from soil data layers. The obtained soil data are converted into a seamless polygon with a comprehensive attribute table. Finally, non-accessible areas such as agricultural lands, urban areas, military facilities, wetlands, national parks, Native American lands, and wildlife refuges are excluded. The remaining areas around the road network are recommended areas for feedstock source restoration. 


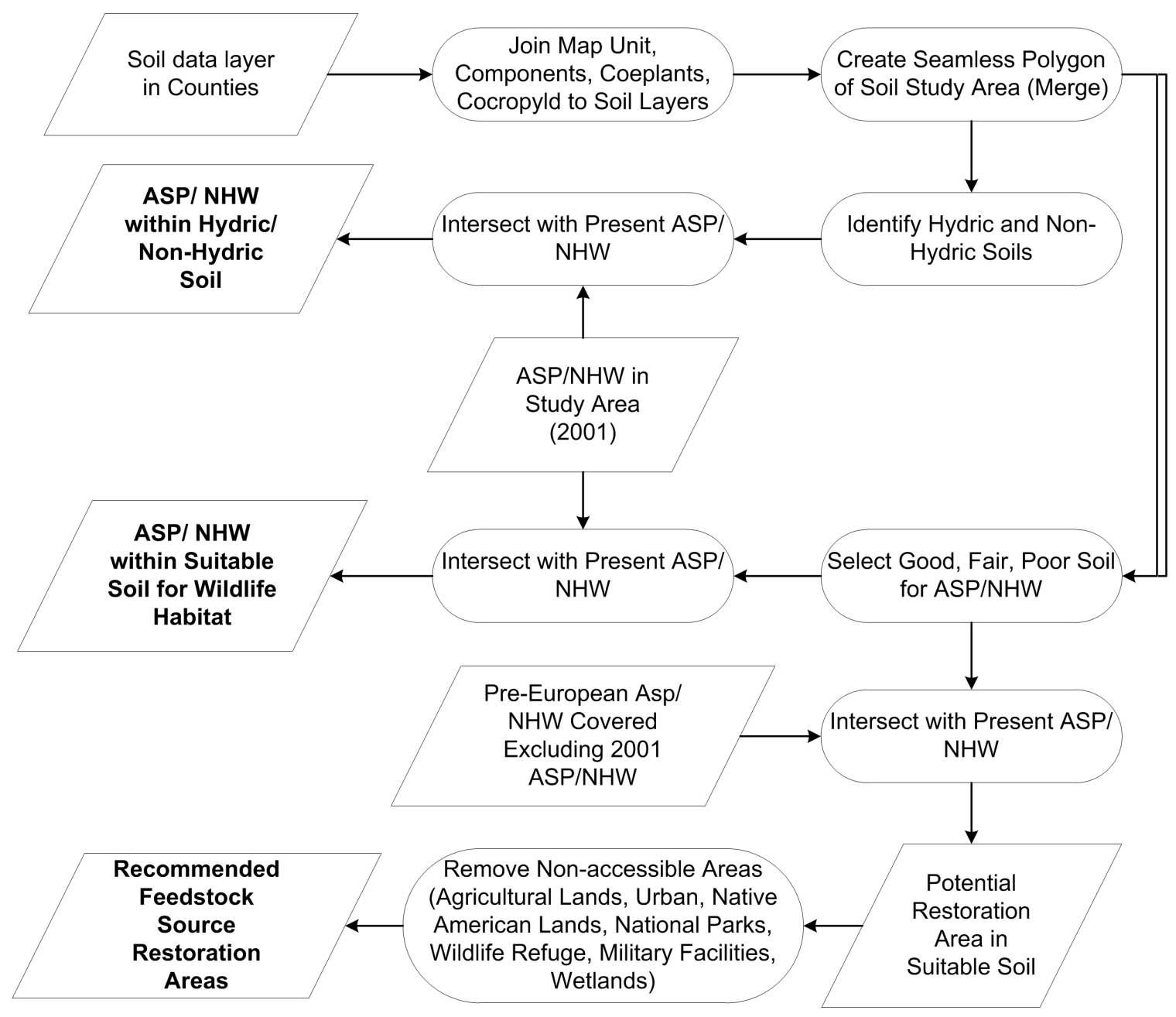

Figure 2.8. Flowchart for identifying potential feedstock restoration areas based on soil characteristics, land accessibility, and comparison between pre-European settlement and present day vegetation. 


\subsection{References}

Graham. S.A. Jr.R.P. Harrison. Jr.C.E. Westell. 1963. Aspens: Phoenix trees of the Great Lakes region. University of Michigan Press, Ann Arbor, MI. 272 p.

Gustafson. E.J. S.M. Lietz. J.L. Wright. 2003. Predicting the spatial distribution of aspen growth potential in the upper Great Lakes region. Forest Science, 49: 499-508.

Michigan Department of Natural Resources (MDNR). 2003. IFMAP/GAP Upper and Lower Peninsula Land Cover. Forest, Mineral, and Fire management Division, Michigan Department of Natural Resources, Lansing, MI.

$<$ http://www.mcgi.state.mi.us/mgdl/?action=meta $>$ (accessed on 3 July 2013).

Snetsinger, S., and S. Ventura. n.d. Land cover change in the Great Lakes Region from mid-nineteenth century to present. Great Lakes Assessment.

$<$ http://www.ncrs.fs.fed.us/gla/reports/LandCoverChange.htm $>$ (accessed on 31 July 2013).

United States Department of Agriculture National Agriculture Statistics Service (USDA NASS), 2011. Crop data layer metadata.

$<$ http://www.nass.usda.gov/research/Cropland/metadata /meta.htm $>$ (Accessed on 10 March 2013).

U.S. Department of Commerce (US DOC). 2011. TIGER/Line Shapefile, 2010, state, Connecticut, Primary and Secondary Roads State-based Shapefile. U.S. Census Bureau, Geography Division, Geographic Products Branch. $<$ http://magic.lib.uconn.edu/magic_2/vector/37800/primarysecondaryroadct_3780 0_0000_2010_s100_census_1_t.htm\#7> (accessed 15 June 2013). 


\section{Chapter 3- Results and Discussion}

\subsection{Introduction}

The compiled land use/cover data are used to characterize aspen and northern hardwoods extent in 2001 and the pre-European settlement era. The results show a significant amount of northern hardwoods converted to other land use/cover types since European settlement, and aspen stands are less contiguous. Furthermore, a significant amount of woody biomass is available in close proximity to the existing road network, which can be effectively utilized as feedstock for the Kinross plant. Potential aspen and northern hardwoods restoration areas are identified in the vicinity of roads, which can be evaluated for future and increased woody feedstock production.

\subsection{Aspen and Northern Hardwoods Distribution Circa 2001}

Leefers and Vasievich (2010) used 4,975 measured inventory plots to analyzed timber resources and availability within 150 miles from the Kinross biofuel production facility. They identified 3.3 million ha ( 8.3 million ac) of timber land area in the study region of which $48 \%$ are located in the UP and $52 \%$ in the LP. Furthermore, their estimates suggest that there are approximately 0.2 billion cubic meters ( 6.4 billion cubic feet) of growing stock volume of hardwoods in the study region. The analysis of aspen and northern hardwoods presented in this thesis focuses only on spatial extent of these feedstock sources. Approximately, a total of $1,254,525$ ha $(3,100,000$ ac) of aspen and northern hardwoods were identified by the current analysis in the study area. The main reason for the discrepancy between the timberland area estimated by Leefers and 
Vasievich (2010) and this study is due to the fact that the former analysis includes both hardwoods and softwood species in the study area.

Aspen and northern hardwoods associations are two individual land use classes from a total of 32 classes in the IFMAP (circa 2001) land use/cover map. Since aspen and northern hardwoods sites are the focus of this study, all remaining land uses and covers were reclassified as "others." There are large contagious stands of northern hardwoods $\sim 124,610$ ha $(307,918 \mathrm{ac})$ in the northern part of the study site in the UP $(\sim 30 \%$ of the northern hardwoods in the UP study area). The sizes of these stands are between 10,00067,640 ha $(24,711-167,142 \mathrm{ac})$. The large stands in the western part of the LP of Michigan are $\sim 131,100$ ha $(323,955 \mathrm{ac})$. These stands are between $1,000-18,060$ ha $(2,471-44,627$ ac) large and they contain $\sim 38 \%$ of the northern hardwoods in the LP. There are a few large aspen stands in the range of 1,000-3,370 ha $(2,471-8,328$ ac) in the UP and LP study areas.

Also, there are small northern hardwoods stands between 1-1,000 ha (2.5-2,471 ac) scattered throughout the area. A total of 564,165 ha $(1,394,082 \mathrm{ac})$ of aspen and northern hardwoods is identified in the UP, and 689,890 ha $(1,704,755$ ac) in the LP study areas. Appendix A summarizes aspen and northern hardwoods distribution in the 33 counties within the study area. Table 3.1 summarizes the breakdown of aspen and northern hardwoods distribution within the specified buffer zones of 50, 100, and 150 miles from Kinross plant. Figure 3.1 shows that scattered aspen stands are located throughout the study area. 
Table 3.1. Aspen and northern hardwoods distribution within buffer zones of 50, 100, and 150 miles from Kinross plant.

\begin{tabular}{cccccc}
\hline Location & Feedstock & $\mathbf{5 0}$ miles & $\mathbf{5 0 - 1 0 0}$ miles & $\begin{array}{c}\mathbf{1 0 0 - 1 5 0} \\
\text { miles }\end{array}$ & Total \\
\hline \multirow{4}{*}{ UP } & ASP (ha) & 81,500 & 36,000 & 50,000 & 167,500 \\
& NHW (ha) & 79,200 & 136,200 & 181,265 & 396,665 \\
\cline { 2 - 6 } & Total (ha) & $\mathbf{1 6 0 , 7 0 0}$ & $\mathbf{1 7 2 , 2 0 0}$ & $\mathbf{2 3 1 , 2 6 5}$ & $\mathbf{5 6 4 , 1 6 5}$ \\
\cline { 2 - 6 } & ASP (ac) & 201,390 & 88,960 & 123,550 & 413,900 \\
& NHW (ac) & 195,700 & 336,560 & 447,915 & 980,175 \\
& Total (ac) & $\mathbf{3 9 7 , 0 9 0}$ & $\mathbf{4 2 5 , 5 2 0}$ & $\mathbf{5 7 1 , 4 6 5}$ & $\mathbf{1 , 3 9 4 , 0 7 5}$ \\
\hline \multirow{3}{*}{ LP } & ASP (ha) & 11,620 & 148,600 & 185,000 & 345,220 \\
& NHW (ha) & 10,780 & 164,700 & 169,190 & 344,670 \\
& Total (ha) & $\mathbf{2 2 , 4 0 0}$ & $\mathbf{3 1 3 , 3 0 0}$ & $\mathbf{3 5 4 , 1 9 0}$ & $\mathbf{6 8 9 , 8 9 0}$ \\
\cline { 2 - 6 } & ASP (ac) & 28,710 & 367,200 & 457,145 & 853,055 \\
& NHW (ac) & 26,640 & 406,990 & 418,100 & 851,700 \\
& Total (ac) & $\mathbf{5 5 , 3 5 0}$ & $\mathbf{7 7 4 , 1 9 0}$ & $\mathbf{8 7 5 , 2 4 5}$ & $\mathbf{1 , 7 0 4 , 7 5 5}$ \\
\hline
\end{tabular}




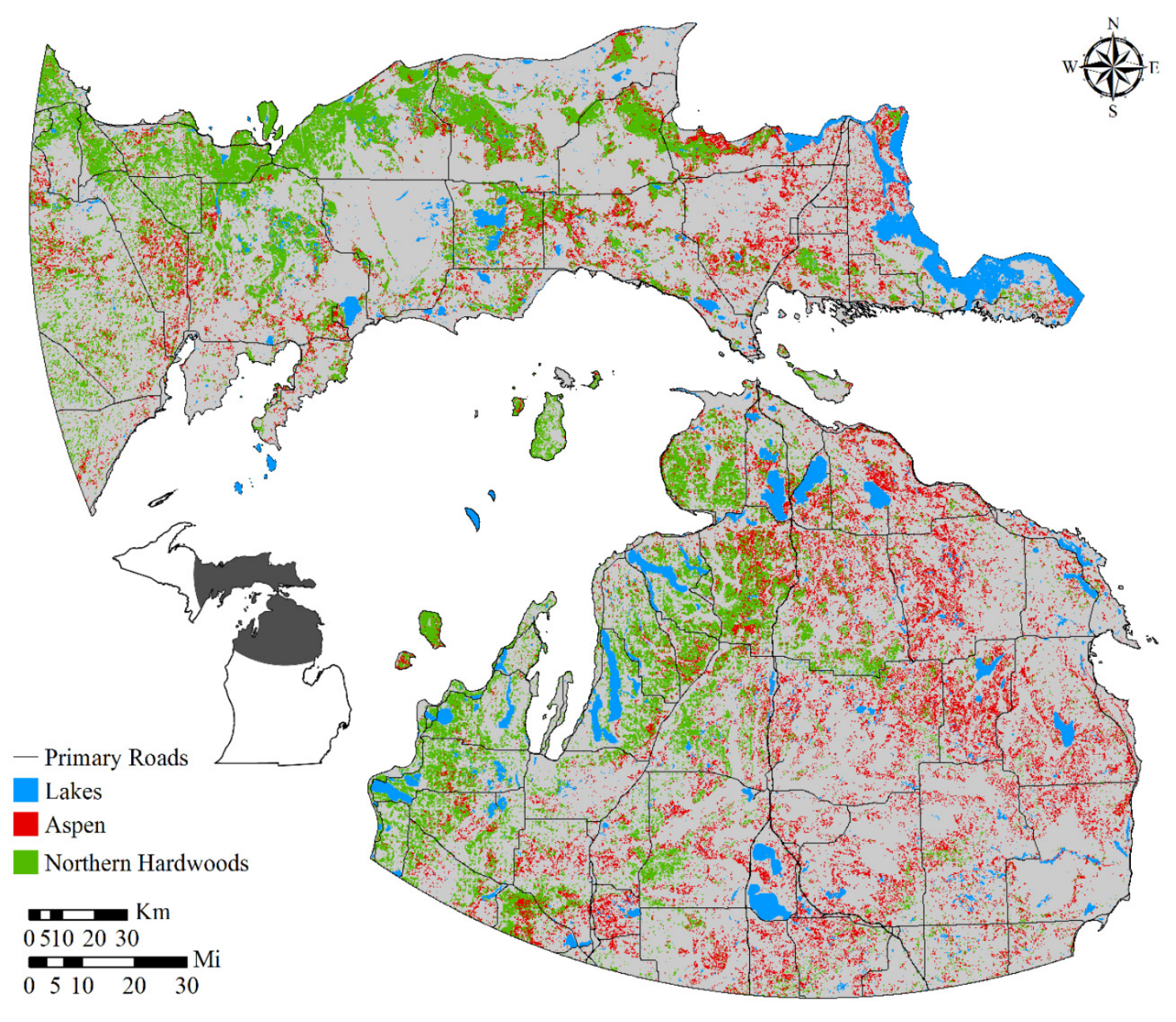

Figure 3.1. 2001 Aspen and northern hardwoods stands in the UP and LP study areas.

\subsection{Current agricultural lands suitable for potential feedstock production}

Croplands in the study area are mostly classed as prime farmlands or locally important farmlands. The land in prime farmlands has the best combination of physical and chemical characteristics suitable for high yields of different crops (USDA NRCS, 2013). Locally important farmlands are those that provide locally important agricultural 
crops, although these lands are not identified as important at national or state levels. Using the Cropland Data Layer (CDL) 2011, the spatial extent of corn fields (feed, pop, ornamental and sweet corns) was calculated in the UP and LP study area in Michigan because these areas may be potentially suitable for hybrid poplar plantations. Approximately $1 \%$ of the croplands in the UP study area are corn fields $>2$ ha $(5 \mathrm{ac})$. These corn fields are mainly located in the western part of the study area. In the LP study area, $\sim 12 \%$ of croplands are corn located mainly in the northern, eastern, and southern parts; $22 \%$ of the corn fields are located within $100 \mathrm{mi}$ of the Kinross plant (Figures 3.2 and 3.3). According to land use data from the CDL 2011 aspen is currently being planted in northeastern Presque Isle County and southwestern Benzie County of the LP study area (Figures 3.4 and 3.5).

\subsection{Aspen and northern hardwoods distribution circa 1800}

The pre-European land cover map interpreted by the Michigan Natural Features Inventory is used to determine the historical distribution of aspen and northern hardwoods, as well as land use/cover change. The pre-European settlement data shows extensive northern hardwoods stands located in the northern, southern, and western part of the UP study area (Figure 3.6). There were $>754,000$ ha $(1,863,167 \mathrm{ac})$ of northern hardwoods and $\sim 30,000$ ha $(74,131 \mathrm{ac})$ of aspen prior to pre-European settlement in the UP study area. Significant amounts of northern hardwoods stands $\sim 1,417,000$ ha $(3,501,469 \mathrm{ac})$ were available in the western part of the LP, along with small patches of aspen $\sim 33,500$ ha $(82,780 \mathrm{ac})$ scattered in the central, northern, and eastern part of the LP (Figure 3.7). 


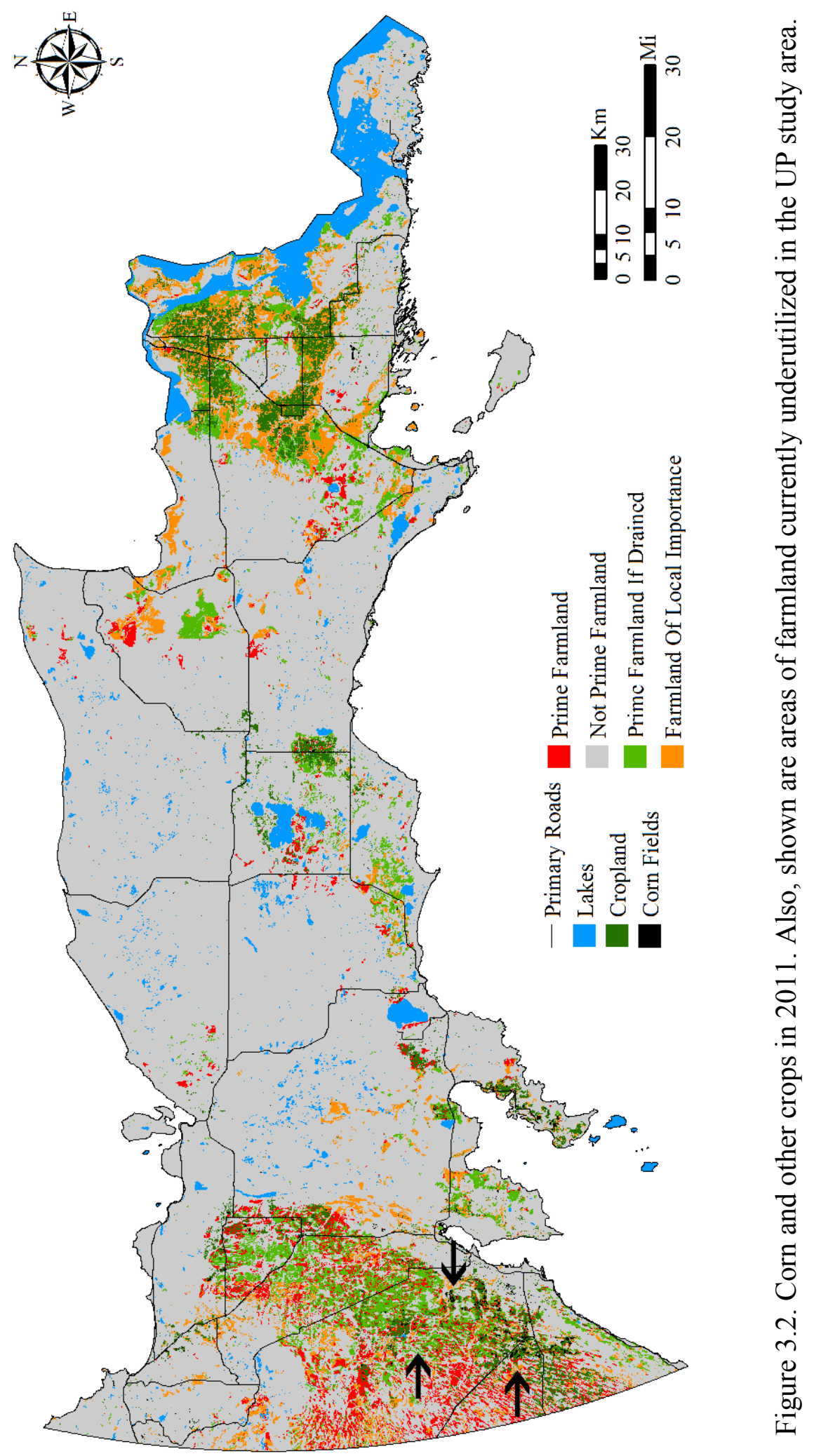




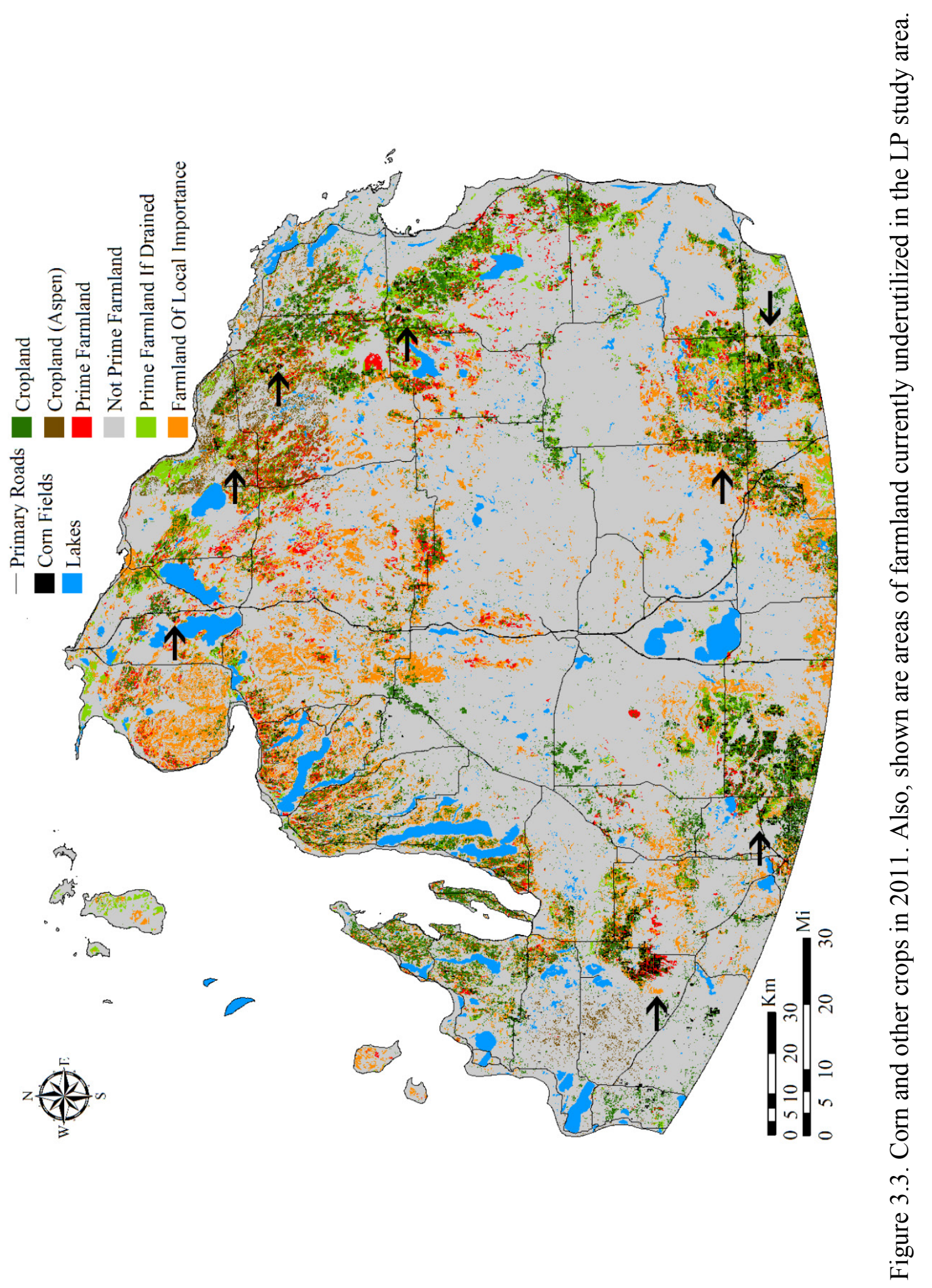




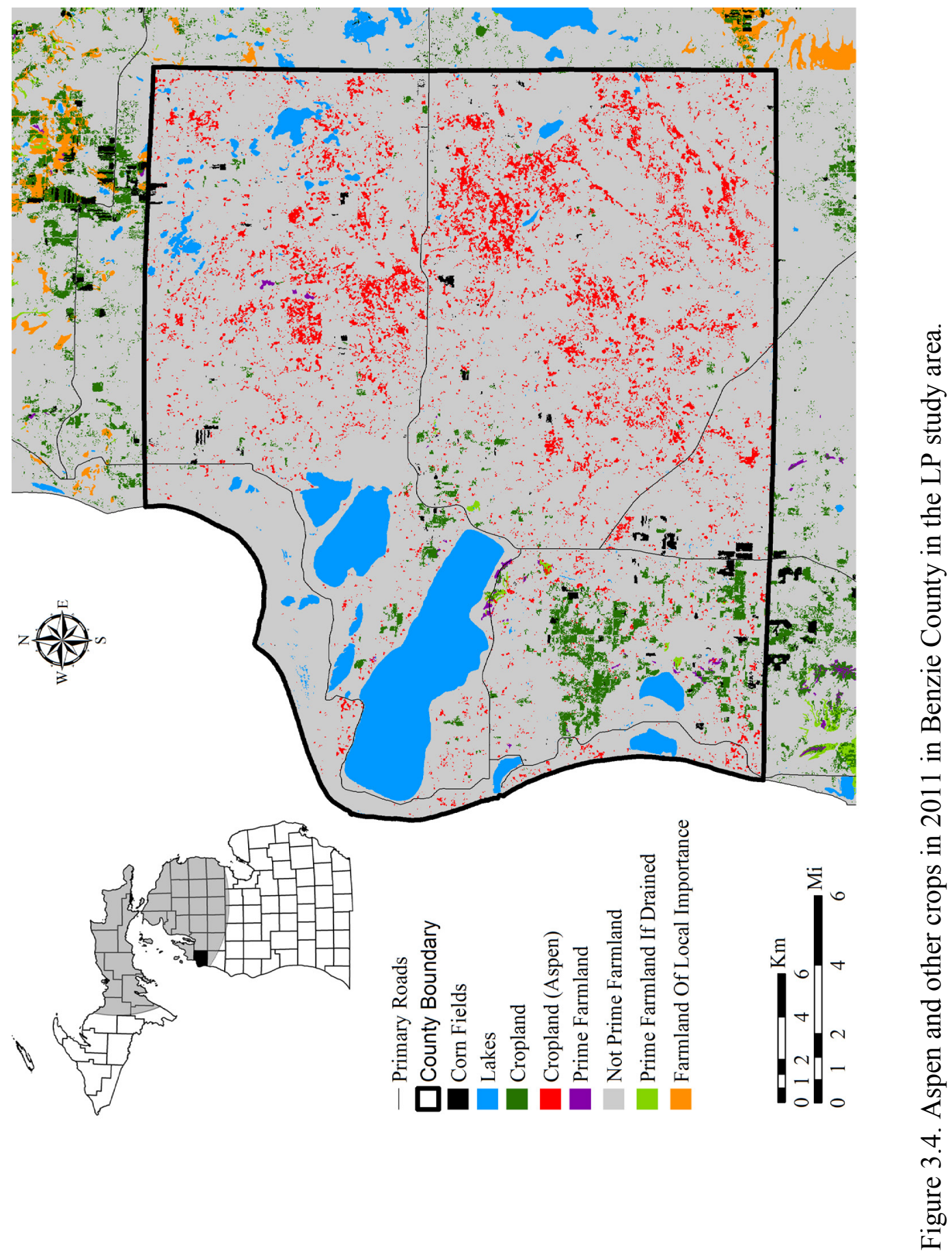




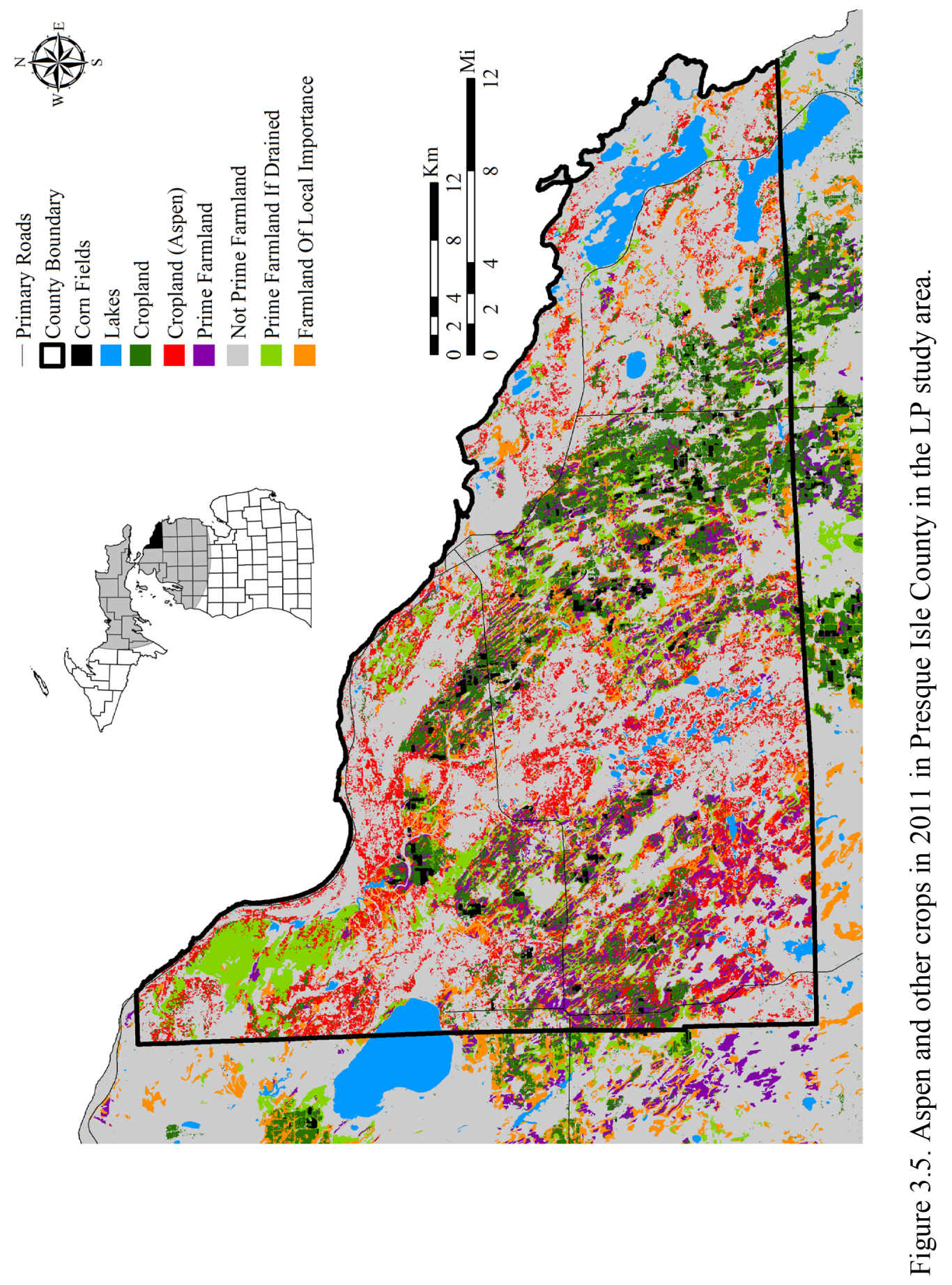




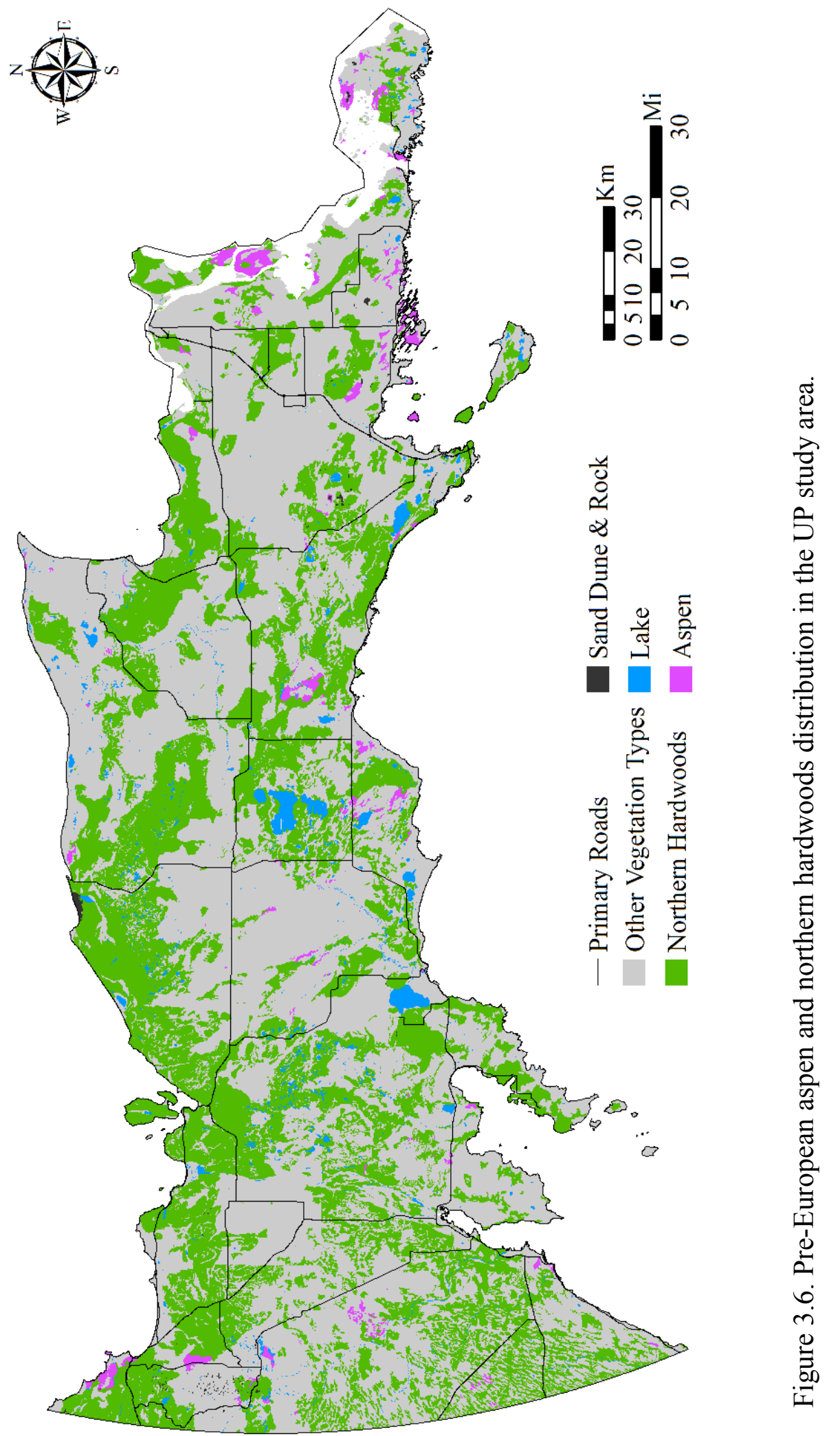




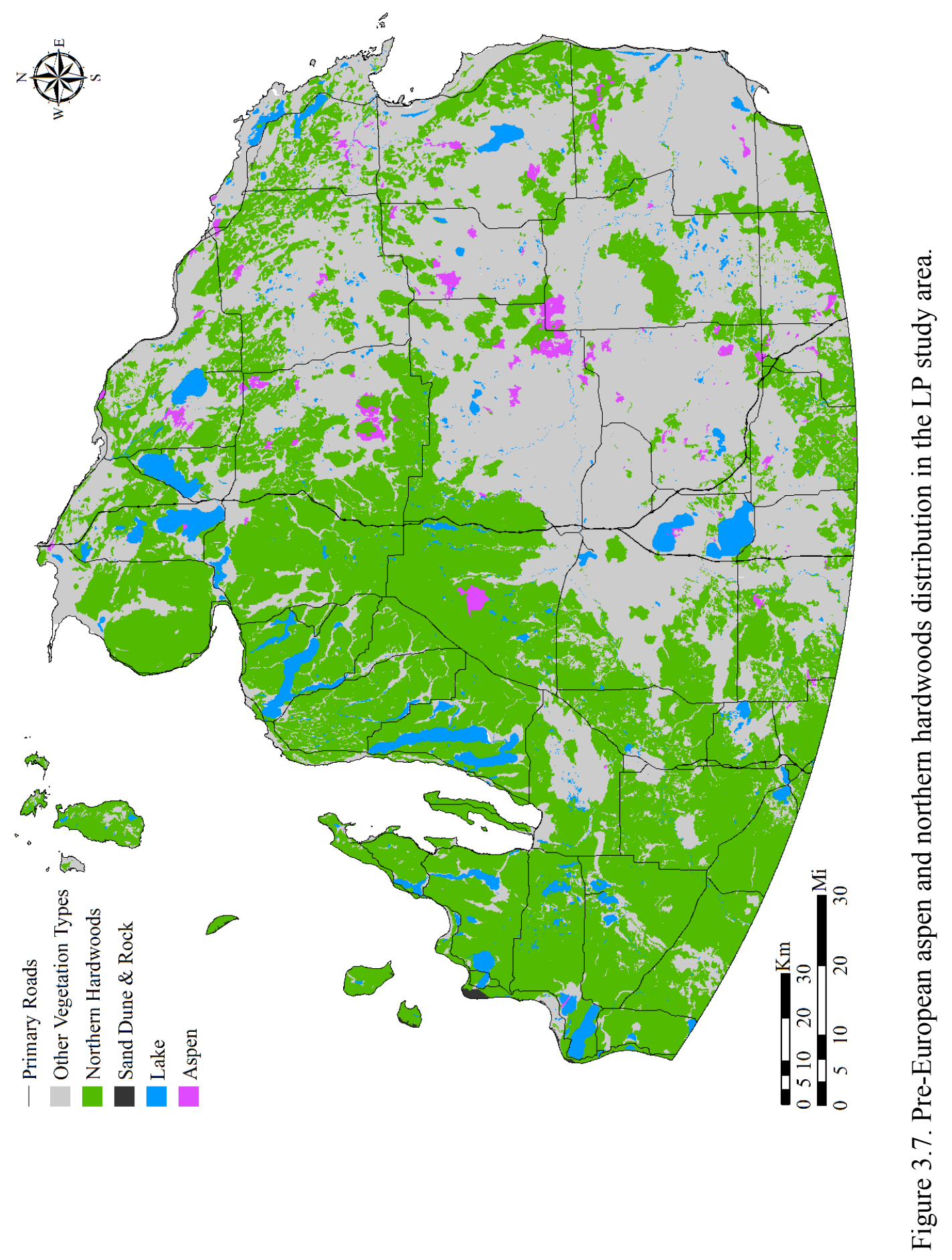


A comparison between the IFMAP and pre-European data shows that there are aspen and northern hardwoods areas that have remained unchanged. In other areas, aspen and northern hardwoods covers have changed to other land uses/covers. Furthermore, IFMAP shows small areas of aspen and northern hardwoods that were covered with other vegetation types in the pre-European settlement era. Table 3.2 compares the size of these three areas.

Table 3.2. Aspen and northern hardwoods change between circa 1800s and 2001.

\begin{tabular}{|c|c|c|c|c|}
\hline Location & ASP/NHW Change & Feedstock & Area (ha) & Area (ac) \\
\hline \multirow{6}{*}{$U P$} & $\begin{array}{l}\text { Common ASP/NHW } \\
\text { areas between circa }\end{array}$ & ASP & 7,000 & 17,300 \\
\hline & 1800 s and 2001 & NHW & 411,415 & $1,016,630$ \\
\hline & $\mathrm{ASP} / \mathrm{NHW}$ in circa & ASP & 22,740 & 56,190 \\
\hline & $\begin{array}{l}1800 \text { s and not in circa } \\
2001\end{array}$ & NHW & 342,780 & 847,030 \\
\hline & ASP/NHW in circa & ASP & 73,990 & 182,835 \\
\hline & $\begin{array}{l}2001 \text { and not in circa } \\
1800 \text { s }\end{array}$ & NHW & 72,550 & 179,275 \\
\hline \multirow{6}{*}{ LP } & $\begin{array}{l}\text { Common ASP/NHW } \\
\text { areas between circa }\end{array}$ & ASP & 7,020 & 17,340 \\
\hline & $1800 \mathrm{~s}$ and 2001 & NHW & 480,315 & $1,186,885$ \\
\hline & ASP/NHW in circa & ASP & 26,530 & 65,560 \\
\hline & $\begin{array}{l}1800 \text { s and not in circa } \\
2001\end{array}$ & NHW & 936,595 & $2,314,380$ \\
\hline & ASP/NHW in circa & ASP & 174,030 & 430,030 \\
\hline & $\begin{array}{l}2001 \text { and not in circa } \\
1800 \text { s }\end{array}$ & NHW & 28,620 & 70,720 \\
\hline
\end{tabular}


Fifty-four percent of the northern hardwoods and $24 \%$ of the aspen has been converted to other land uses in the UP study area (Table 3.3). In the LP, $34 \%$ of the preEuropean northern hardwoods and $21 \%$ of the aspen has been converted. Significant proportions of the pre-European aspen and northern hardwoods lands in the study area have changed to other forested lands (such as conifer plantations), rangelands and agricultural lands. Figures 3.8 and 3.9 provide maps of land use changes to aspen and northern hardwoods, and other land use types between pre-European settlement era and circa 2001 in the UP and LP study areas. Land use changes to other land use types in the UP and LP study areas are shown in detail in Figures 3.10 and 3.11.

Table 3.3. Land use change from hardwood and aspen to other land uses between circa 1800 and circa 2001.

\begin{tabular}{cccccccc}
\hline \multirow{2}{*}{$\begin{array}{c}\text { Location } \\
\text { (Feedstock) }\end{array}$} & Unit & \multicolumn{7}{c}{ Land Use/Cover } \\
\cline { 3 - 7 } & & Forested & Agricultural & Barren & Rangeland & Urban & Wetland \\
\hline $\begin{array}{c}\text { UP } \\
(\mathbf{A S P})\end{array}$ & ha & 15,950 & 515 & 310 & 3,600 & 860 & 1,300 \\
& ac & 39,390 & 1,300 & 770 & 9,000 & 2,140 & 3,200 \\
$\mathbf{U P}$ & ha & 213,240 & 32,240 & 3,530 & 71,450 & 12,070 & 8,850 \\
$\mathbf{( N H W )}$ & ac & 526,925 & 79,670 & 8,725 & 176,560 & 29,820 & 21,870 \\
$\mathbf{L P}$ & ha & 13,400 & 2,810 & 480 & 5,630 & 770 & 500 \\
$(\mathbf{A S P})$ & ac & 33,120 & 6,950 & 1,190 & 13,900 & 1,900 & 1,220 \\
$\mathbf{L P}$ & ha & 389,535 & 215,745 & 6,844 & 264,200 & 43,960 & 12,350 \\
$(\mathbf{N H W})$ & ac & 962,560 & 533,120 & 16,910 & 652,845 & 108,620 & 30,525 \\
\hline
\end{tabular}




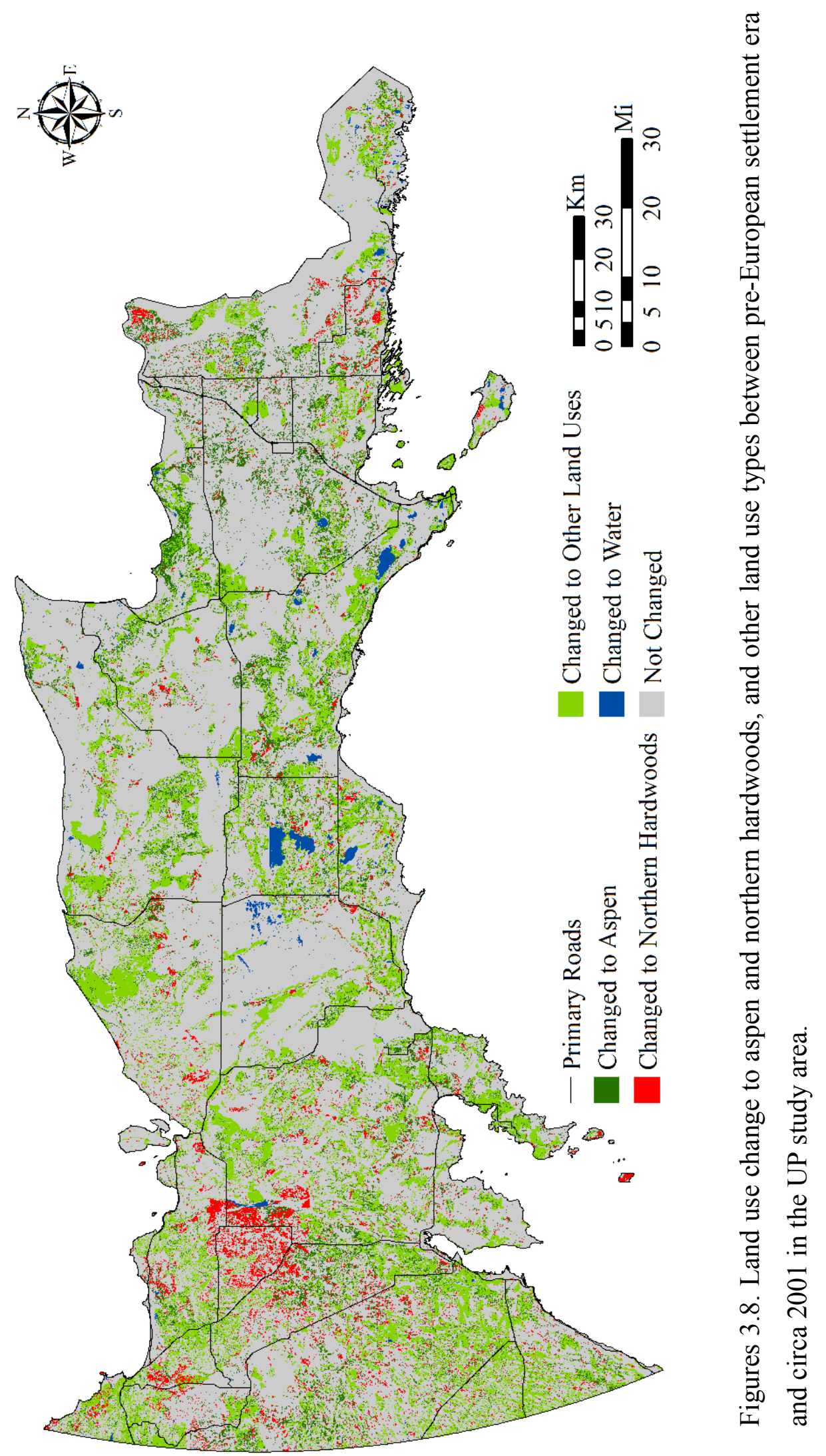




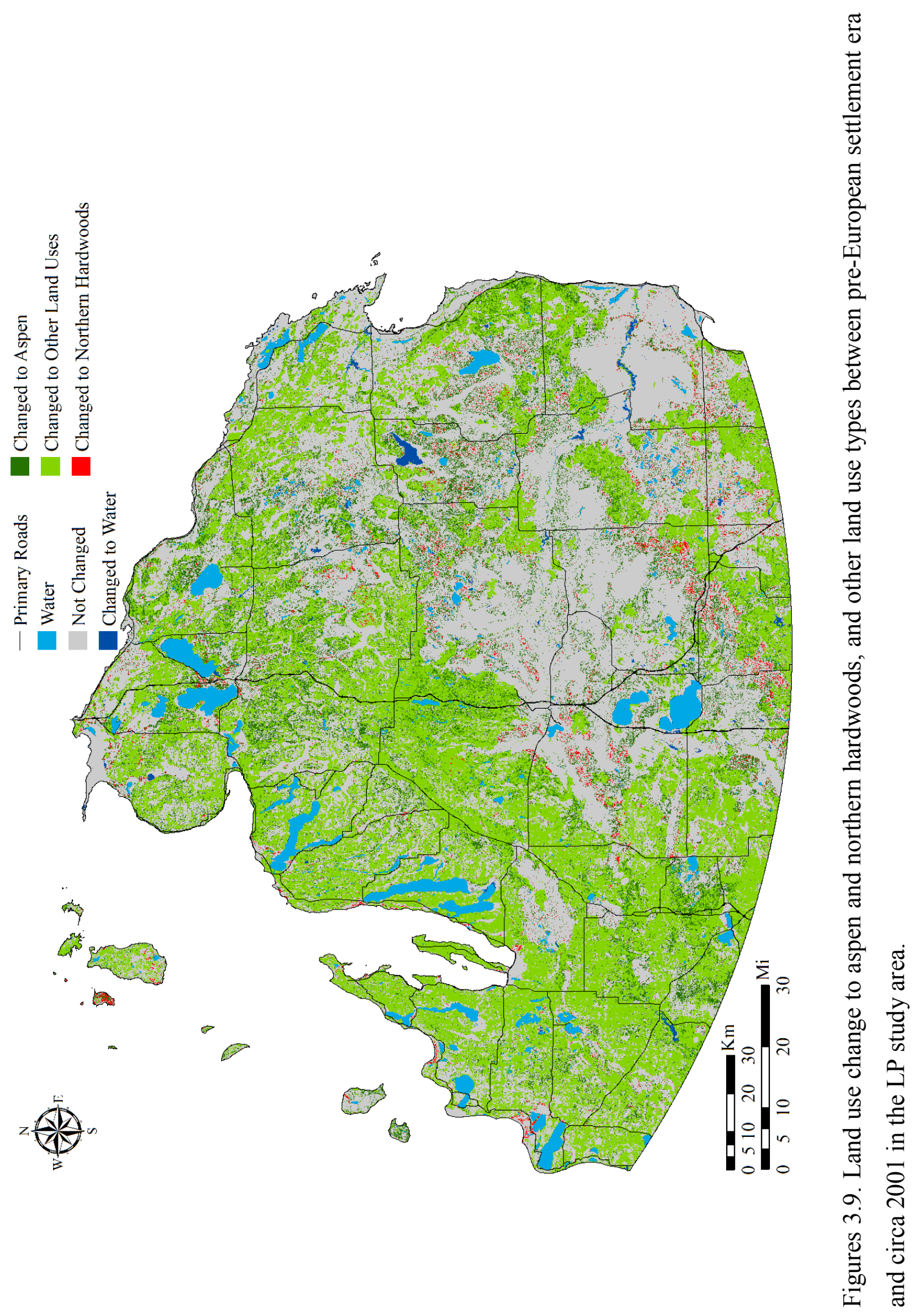




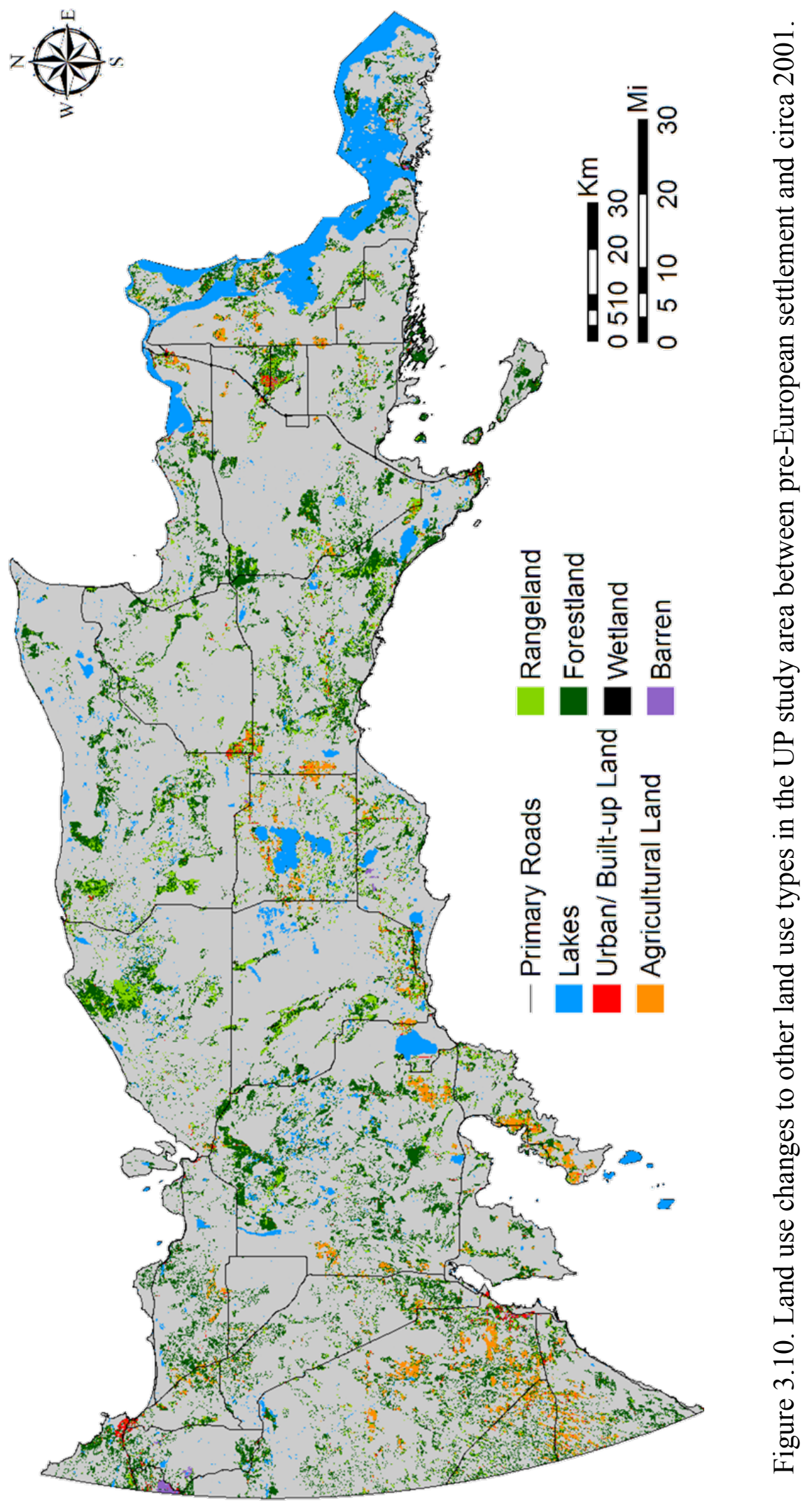



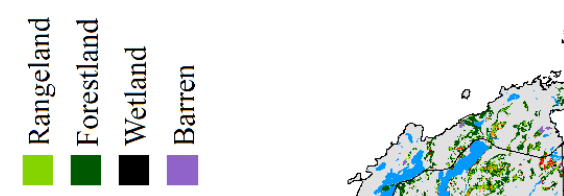

.
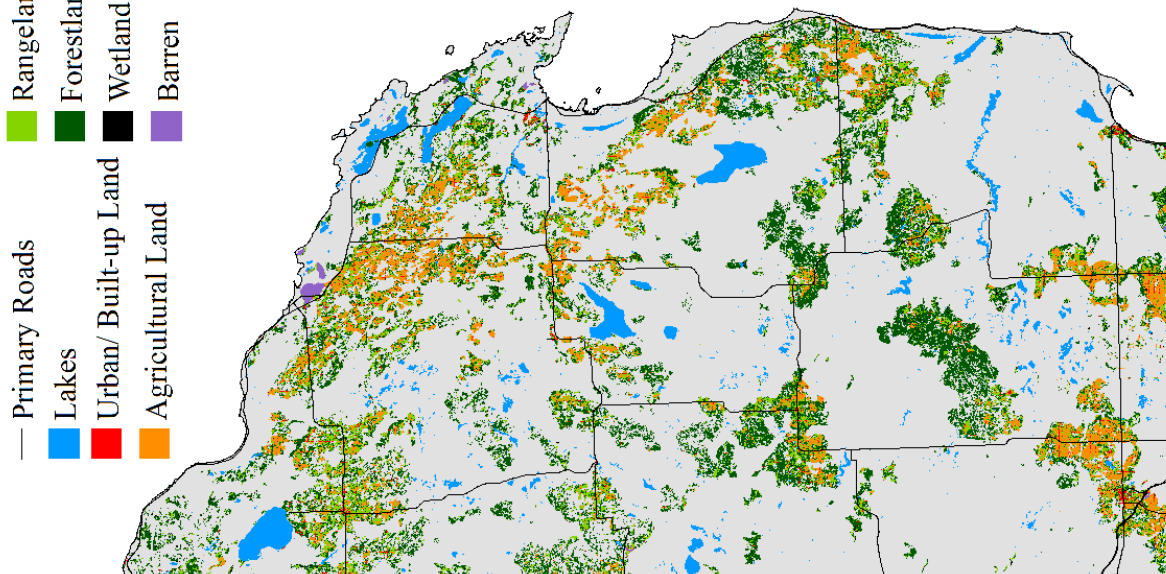

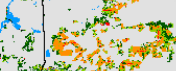
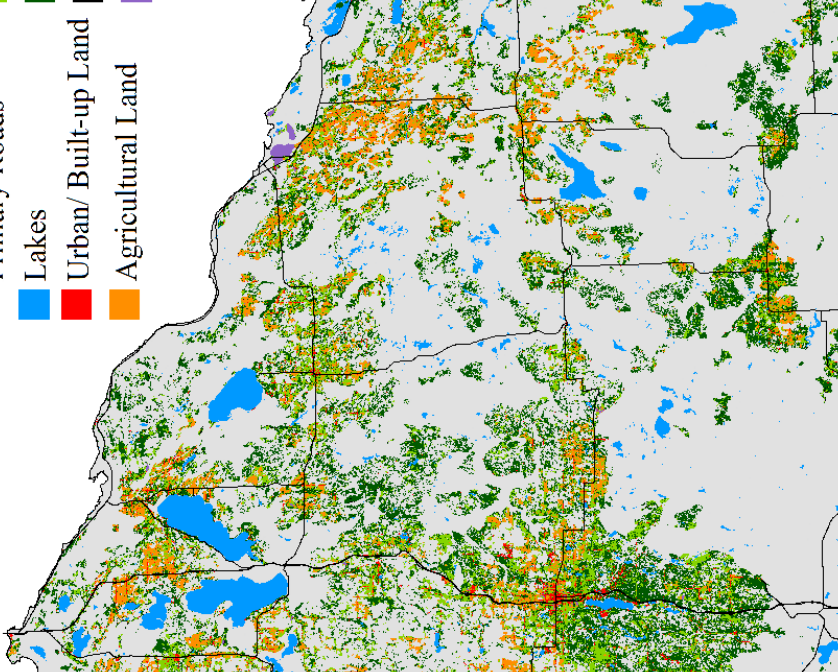

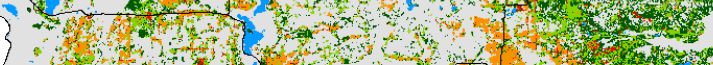
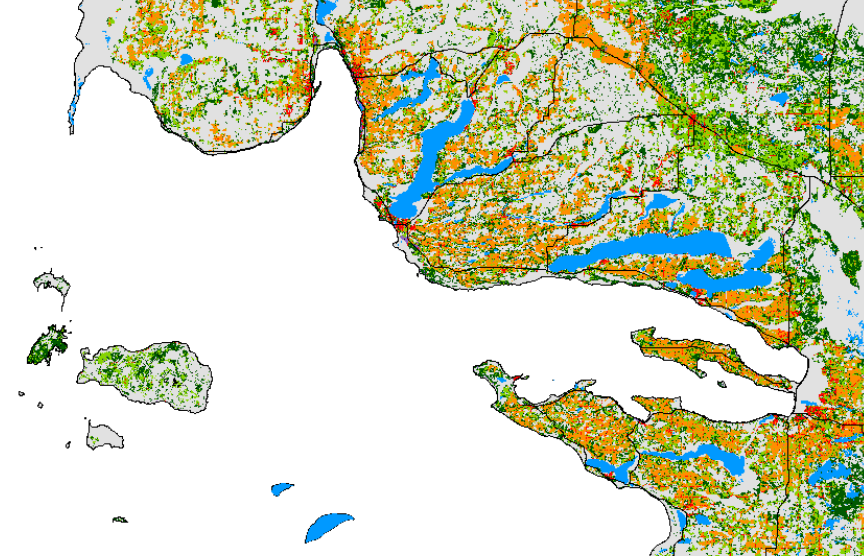

雪
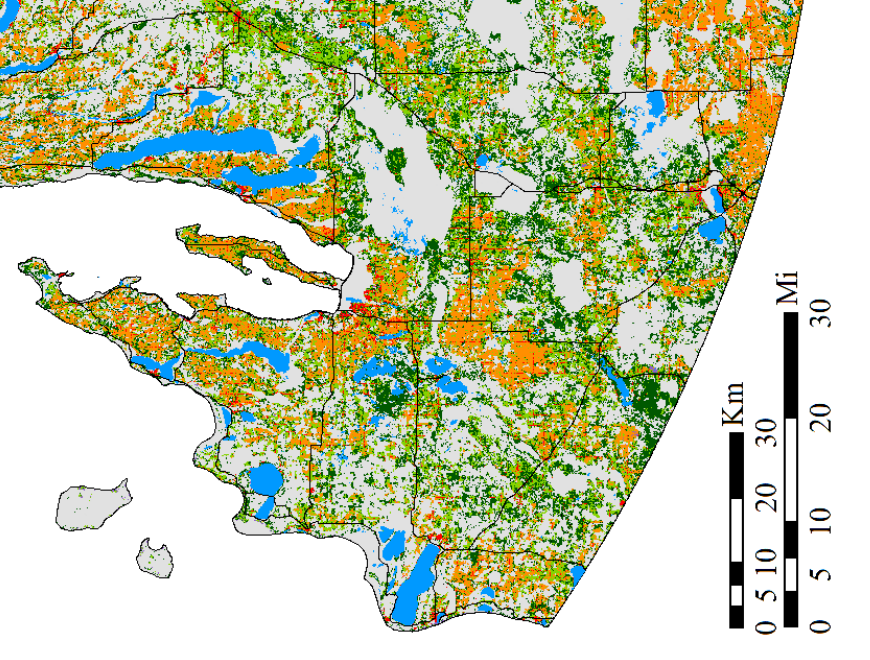

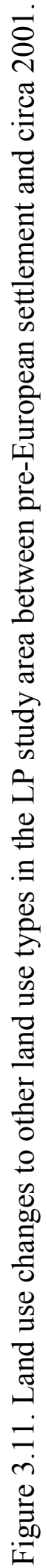




\subsection{Feedstock sources around existing road networks}

Table 3.5 summarizes the present amount of aspen and northern hardwoods within incremental distance buffers from the primary and secondary road network in different soil types (hydric and non-hydric soils) in the UP and LP study area. The table excludes lands that are have restricted access such as wildlife refuges, military installations and national and state parks and Native American lands. The analysis shows that most of the aspen and northern hardwoods, i.e., $>175,000$ ha $(432,433 \mathrm{ac})$ and $>372,000$ ha $(919,228$ ac) in the UP and LP, respectively, is available within 0.25 mile of a primary or secondary road. Most of the feedstock sources are located on non-hydric soil sites (Table 3.4). Feedstock extent sharply declines as distance from the road network increases (Figure $3.12 \mathrm{a}$ and $3.12 \mathrm{~b}$ ). The results show these feedstock volumes are within economically viable distances to the existing road network (Figures 3.13 and 3.14). 


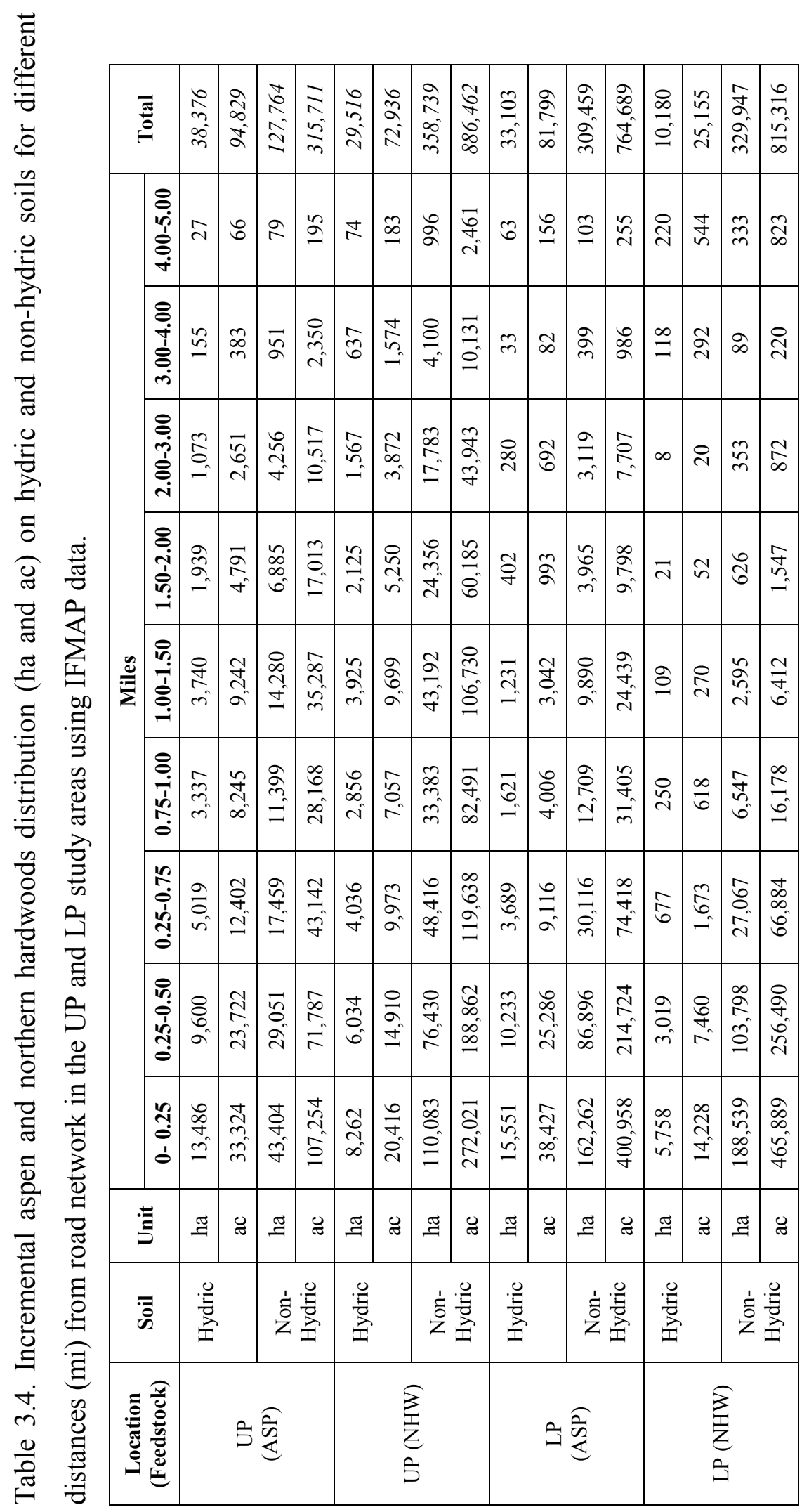



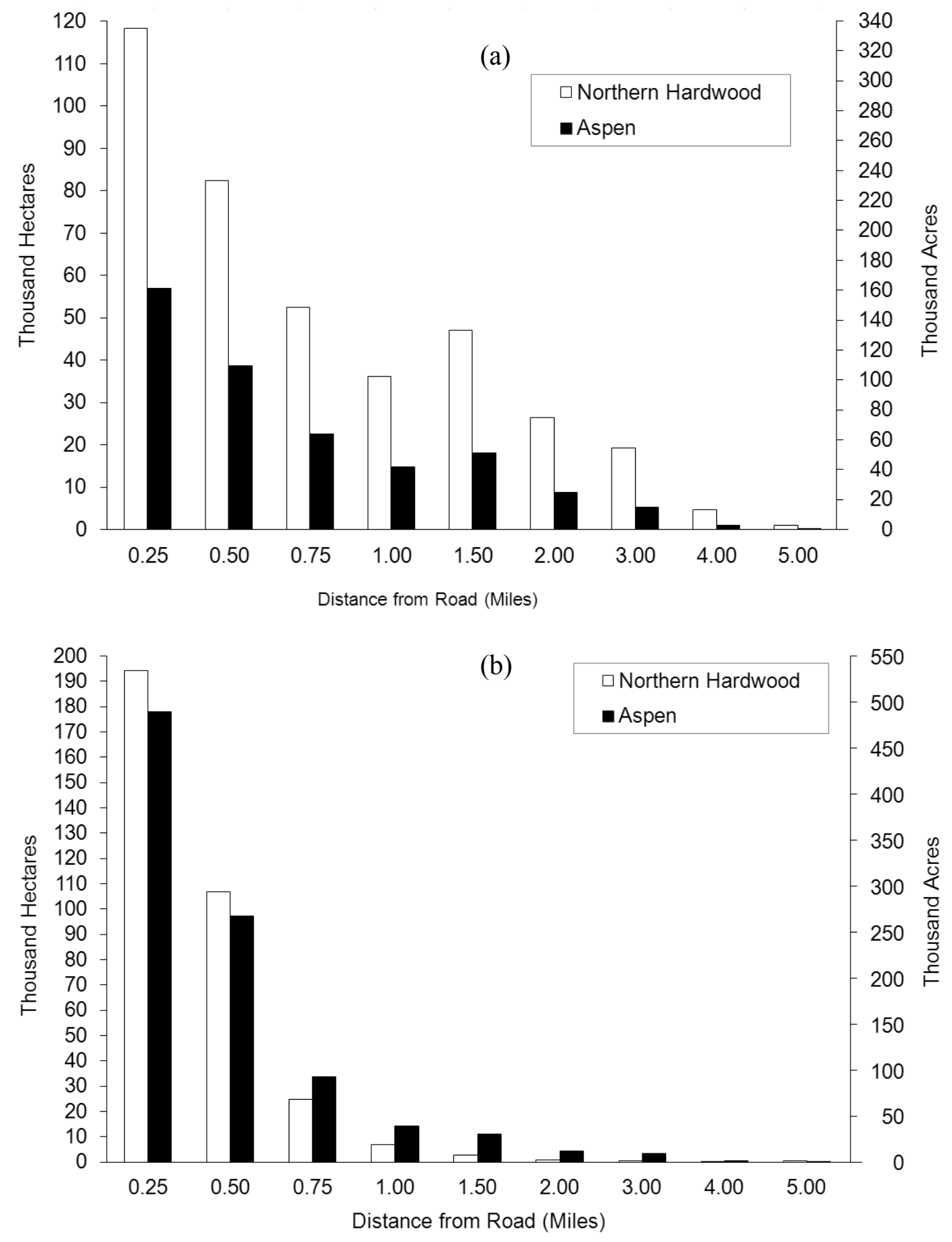

Figure 3.12. Proximity of aspen and northern hardwoods to the road network in the UP (a) and LP (b) in the study area using IFMAP data. 


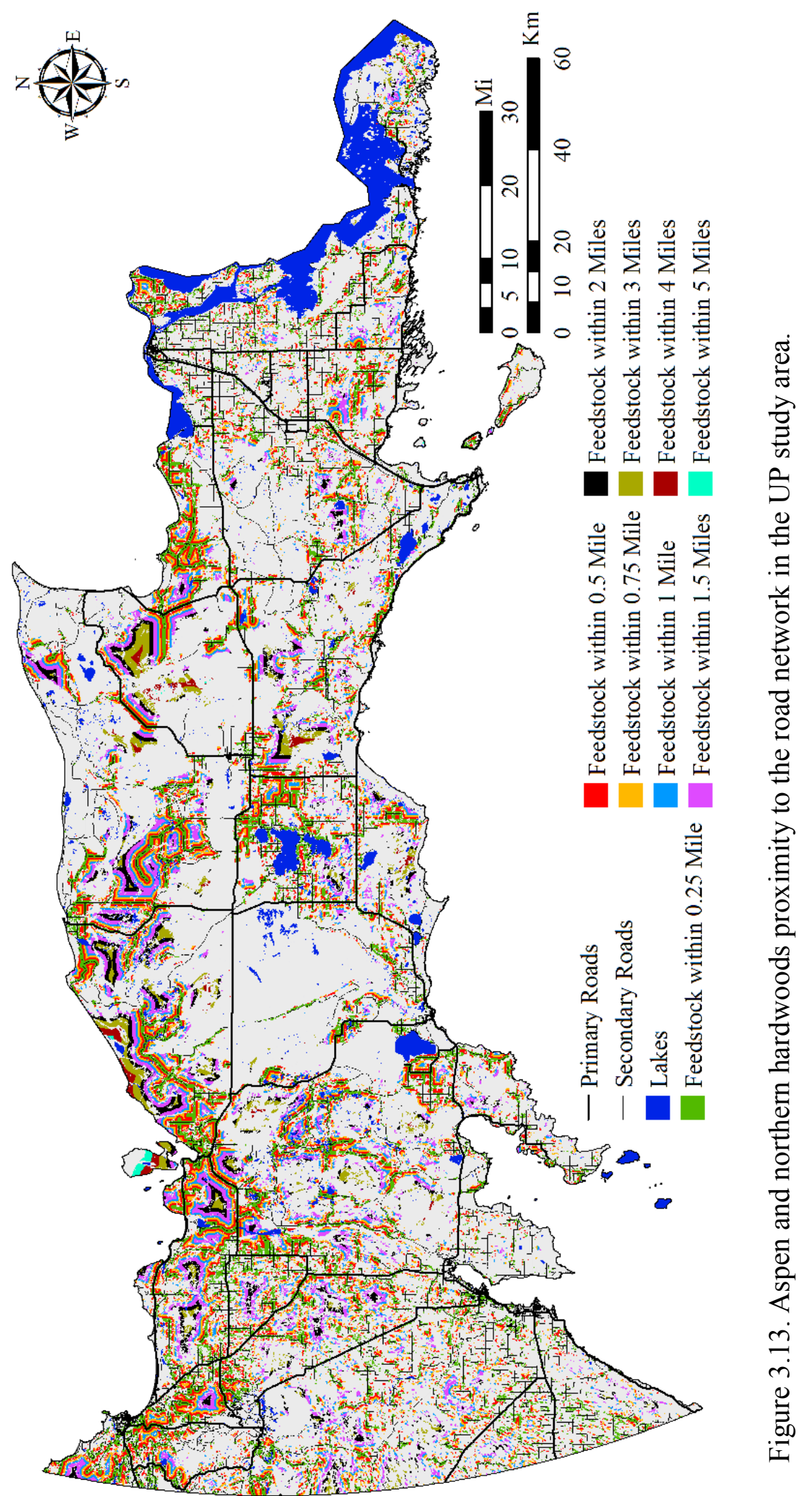




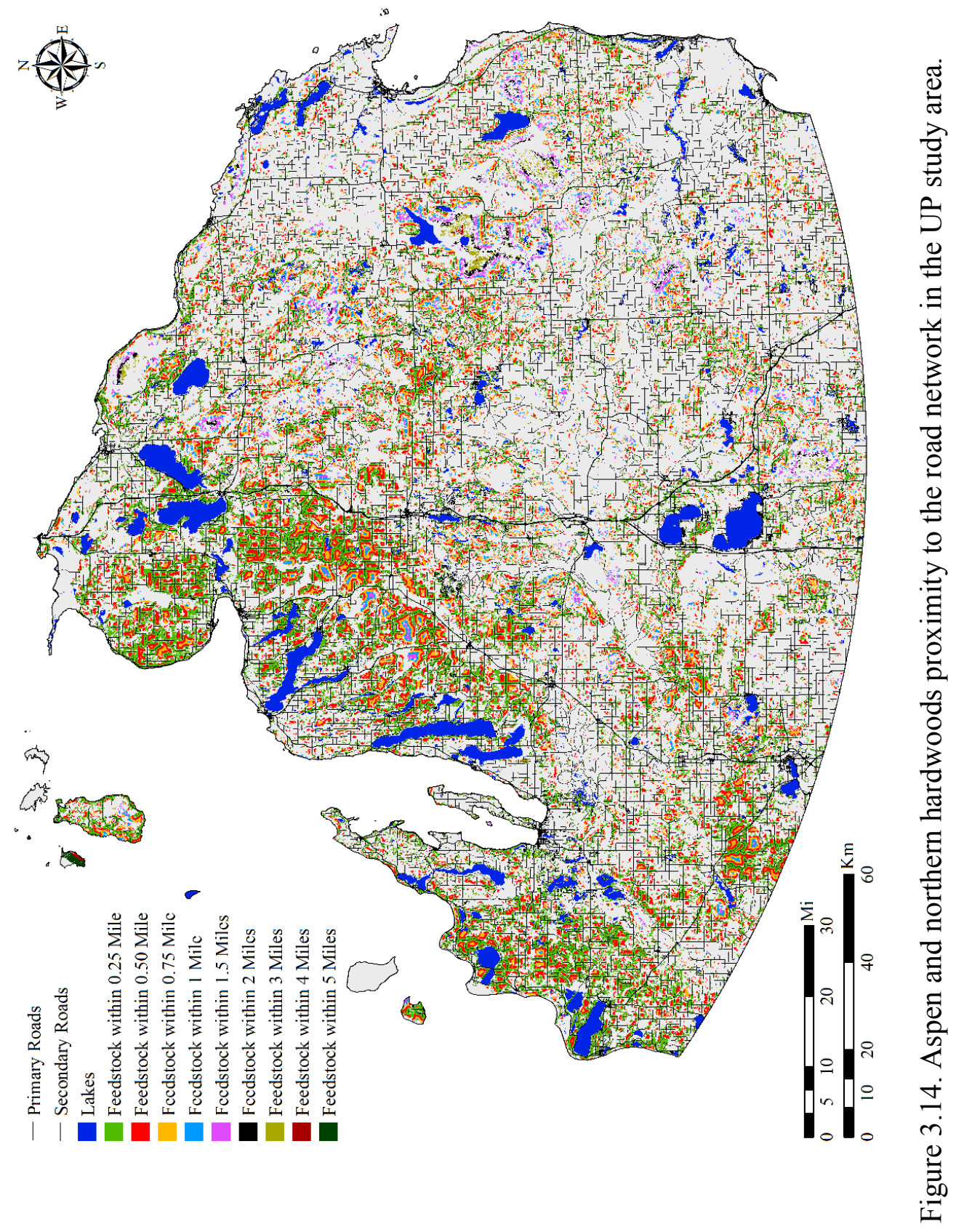




\subsection{Potential feedstock source restoration areas}

Pre-European settlement aspen and northern hardwoods forest location and extent can provide guidance in estimating the area's potential for feedstock production. In order to identify potential aspen and northern hardwoods forest restoration areas with convenient access to roads, the historical extent of northern hardwoods and aspen in relation the road networks is characterized. This is done by overlaying the present-day road networks on the pre-European settlement land cover, and estimating incremental changes in the amount of aspen and northern hardwoods forests around the road network. The results indicate significant potential aspen and northern hardwoods restoration areas exist within one mile of the road network, which could potentially increase the feedstock extent by over $100 \%$ and $45 \%$ in the UP and LP study areas, respectively. Table 3.5 and Figures $3.15 \mathrm{a}$ and $3.15 \mathrm{~b}$ show a decreasing extent of aspen and northern hardwoods extent with distance from road network. Figures 3.16 and 3.17 show the locations of buffers around the road network. 
Table 3.5. Incremental proximity of pre-European aspen and northern hardwoods to the road network in the UP and LP study areas.

\begin{tabular}{|c|c|c|c|c|c|}
\hline \multirow{2}{*}{ Location } & \multirow{2}{*}{ Miles } & \multicolumn{2}{|c|}{ Aspen } & \multicolumn{2}{|c|}{ Northern hardwoods } \\
\hline & & (ha) & (ac) & (ha) & (ac) \\
\hline \multirow{9}{*}{$\mathbf{U P}$} & $0-0.25$ & 11,878 & 29,351 & 281,074 & 694,548 \\
\hline & $0.25-0.50$ & 5,918 & 14,624 & 154,370 & 381,456 \\
\hline & $0.25-0.75$ & 3,436 & 8,491 & 91,231 & 225,436 \\
\hline & $0.75-1.00$ & 2,104 & 5,199 & 62,735 & 155,021 \\
\hline & $1.00-1.50$ & 2,824 & 6,978 & 79,180 & 195,658 \\
\hline & $1.50-2.00$ & 1,110 & 2,743 & 42,741 & 105,615 \\
\hline & $2.00-3.00$ & 1,764 & 4,359 & 32,423 & 80,119 \\
\hline & $3.00-4.00$ & 170 & 420 & 7,444 & 18,395 \\
\hline & $4.00-5.00$ & 373 & 921 & 1,398 & 3,455 \\
\hline \multirow{9}{*}{$\mathbf{L P}$} & $0-0.25$ & 19,503 & 48,193 & 954,895 & $2,359,593$ \\
\hline & $0.25-0.50$ & 8,605 & 21,263 & 328,527 & 811,807 \\
\hline & $0.25-0.75$ & 2,812 & 6,949 & 75,183 & 185,781 \\
\hline & $0.75-1.00$ & 1,150 & 2,842 & 26,385 & 65,199 \\
\hline & $1.00-1.50$ & 604 & 1,493 & 14,818 & 36,616 \\
\hline & $1.50-2.00$ & 284 & 702 & 4,642 & 11,471 \\
\hline & $2.00-3.00$ & 397 & 981 & 3,890 & 9,612 \\
\hline & $3.00-4.00$ & 195 & 482 & 746 & 1,843 \\
\hline & $4.00-5.00$ & 0 & 0 & 485 & 1,200 \\
\hline
\end{tabular}


(a)

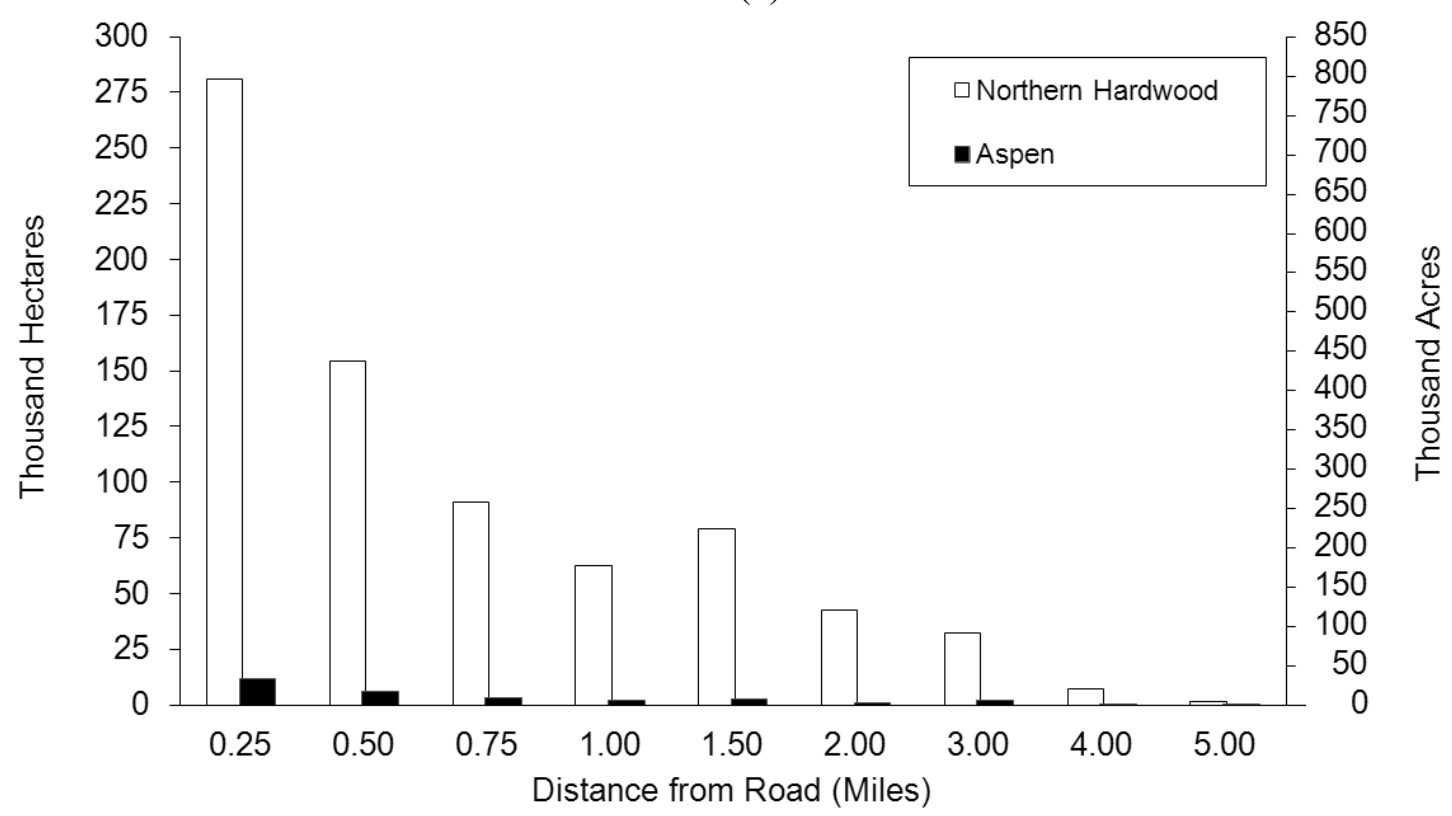

(b)

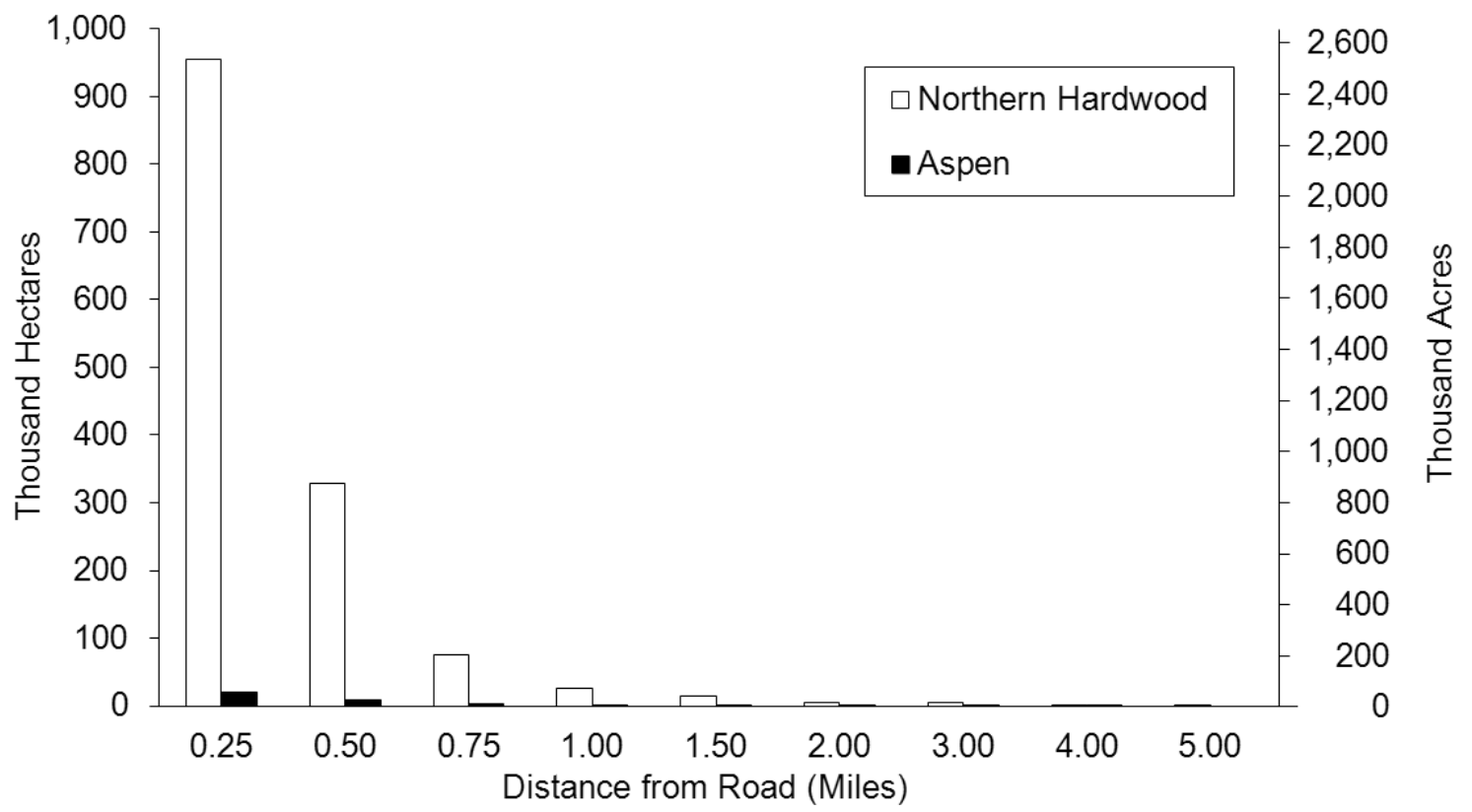

Figure 3.15. Proximity of Pre-European settlement aspen and northern hardwoods areas to the road network in the UP (a) and LP (b) study area. 
In order to provide further insight about potential restoration areas with reference to hydric and non-hydric soils, present day soil data were overlain on the pre-European settlement land cover. This was done to obtain a rough estimate of the number of hectares of aspen and northern hardwoods located on hydric and non- hydric soils. Assuming the areal extent of the present-day hydric and non-hydric soil types is representative of soil conditions in the pre-European settlement era, it was found that $\sim 14 \%$ of the preEuropean settlement aspen and northern hardwoods forests in the UP study area were growing on hydric soils, while about $84 \%$ were on non- hydric soils. In the LP study area, about $7 \%$ of the aspen and northern hardwoods forests were located on hydric soils, and about $91 \%$ were on non- hydric soils. Of the present-day aspen and northern hardwoods forests, which are significantly less abundant compared with pre-European settlement era, approximately $12 \%$ are on hydric soils and $87 \%$ on non- hydric soils in the UP, and $6 \%$ are on hydric soils and 93\% on non-hydric in the LP study areas. 


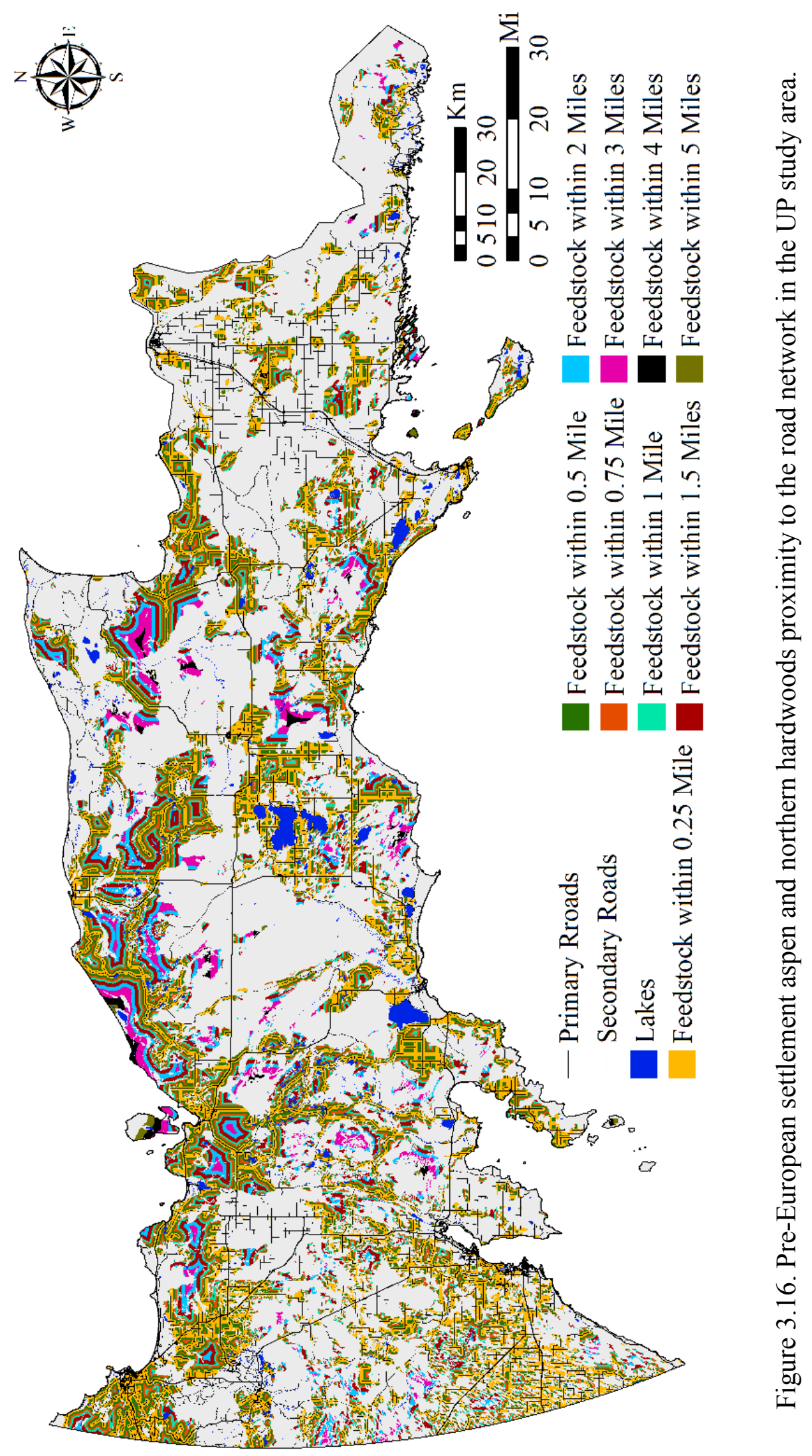




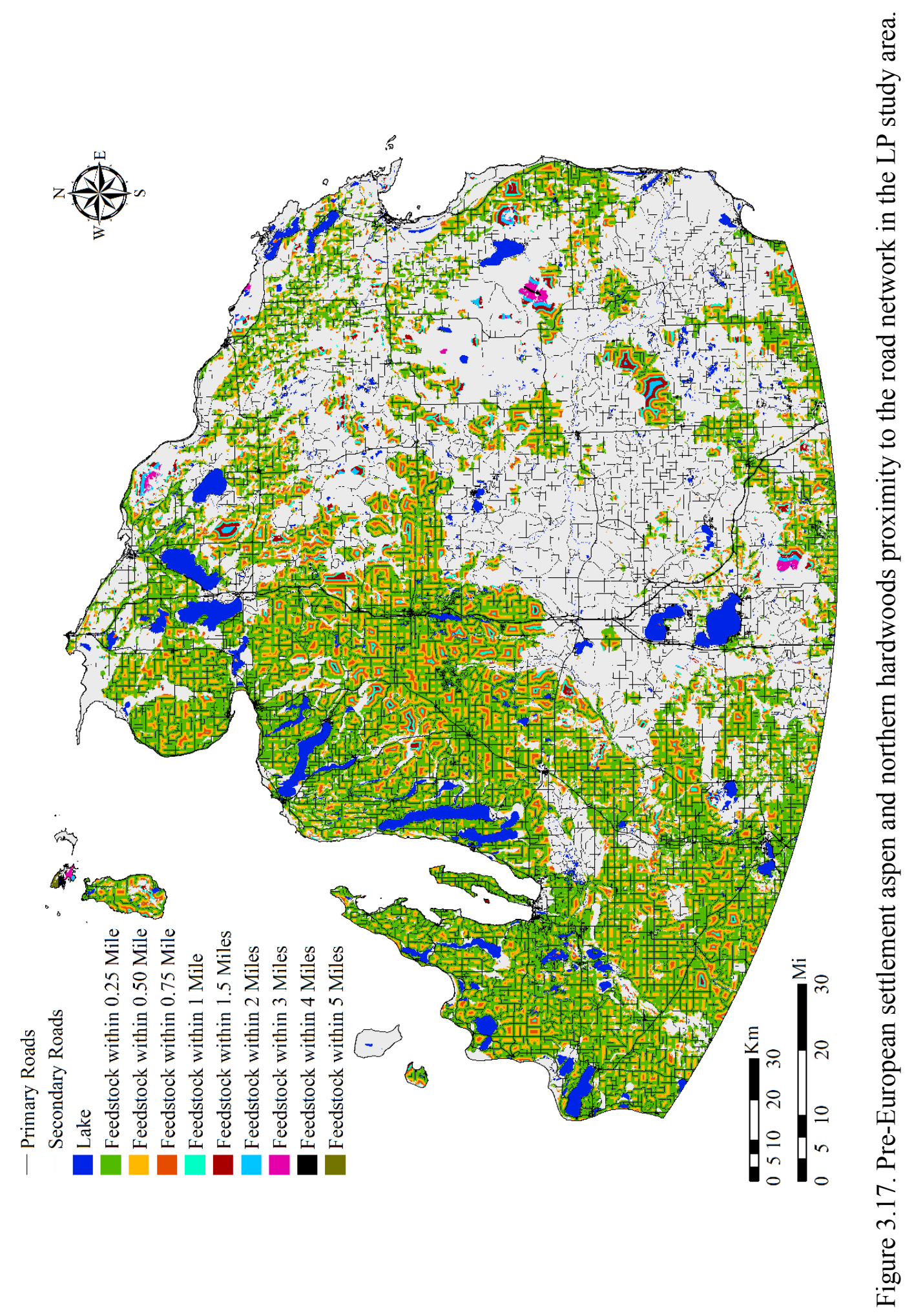




\subsection{Land ownerships}

The study area includes private ownership as well as federal (e.g., national forests, wildlife refuges, national parks and military installations), state (parks, forests and wildlife areas), and Native American lands (Figure 3.18).

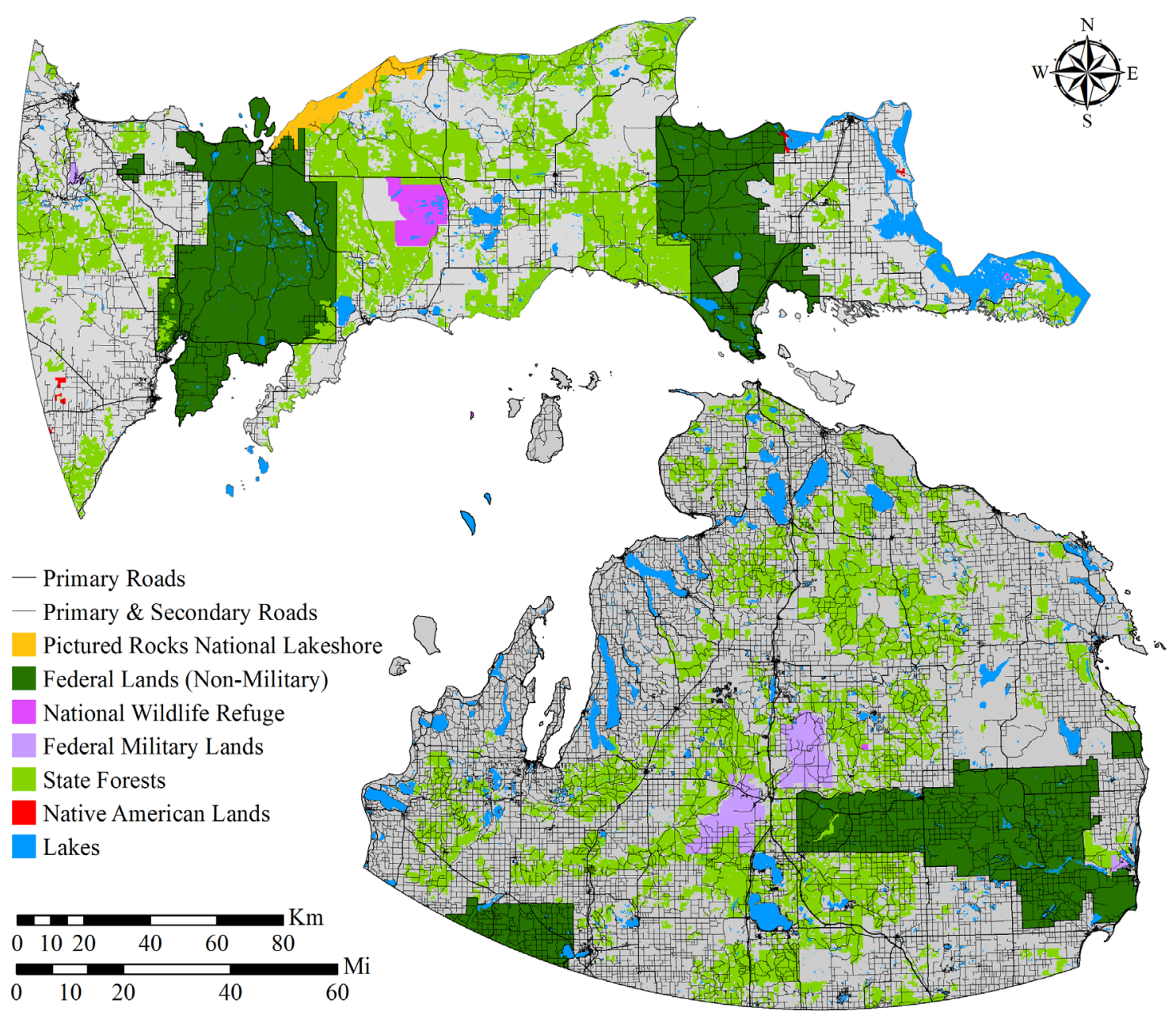

Figure 3.18. Land ownerships in the UP and LP study areas. 
Figure 3.19 and 3.20 show the aspen and northern hardwoods extent within federal and state lands in the study area. These areas can be classified into accessible and nonaccessible areas for feedstock production. Accessible areas for feedstock production consist of national and state forests which can be used depending on available harvesting policies. National forests cover about $24 \%$ of the UP and $11 \%$ of the LP study areas. About $26 \%$ and $8 \%$ of the aspen and northern hardwoods forests are located in the federal lands in the UP and LP study areas, respectively. State forests cover approximately $24 \%$ of the UP and $22 \%$ of the LP study areas, including about $17 \%$ of the total aspen and northern hardwoods in the UP, and 26\% in the LP study areas.

Non-accessible areas are those where access is limited or management policies do not include timber harvesting, including national and state parks, military installations, wildlife refuges, and Native American owned land. Pictured Rocks National Park ( $\sim 1 \%$ of the UP study area) is an example of the non-accessible areas identified within the study area, which includes $\sim 1.4 \%$ of the total aspen and northern hardwoods. A small proportion of the aspen and northern hardwoods in the UP and LP study areas (about $1.2 \%$ ) is located within military installations, which cover about $1.1 \%$ of the UP and LP study areas. Wildlife refuge takes about $1.3 \%$ of the study area, providing less than $0.2 \%$ of aspen and northern hardwoods in the UP and LP study areas. Native American Lands cover an insignificant area (about $0.1 \%$ ) of the UP study area. The non-accessible areas cover a total of $\sim 2.7 \%$ of the study area, comprising approximately $2 \%$ of the area's total aspen and hardwood association. Table 3.6 summarizes non-accessible lands and the amount of aspen and northern hardwoods association (circa 2001) within them. 
Table 3.6. Non-accessible lands in the study area and the corresponding amount of aspen and northern hardwoods association (circa 2001) within them.

\begin{tabular}{lccccc}
\hline $\begin{array}{l}\text { Non-accessible } \\
\text { land }\end{array}$ & $\begin{array}{l}\text { Percent of } \\
\text { study area (\%) }\end{array}$ & $\begin{array}{l}\text { Percent of total } \\
\text { ASP and NHW } \\
(\%)\end{array}$ & \multicolumn{2}{c}{$\begin{array}{c}\text { ASP and NHW } \\
\text { Area }\end{array}$} \\
\hline $\begin{array}{l}\text { Pictured Rocks National } \\
\text { Park }\end{array}$ & 1.0 & 1.4 & 17,557 & 43,384 \\
Military Installations & 1.1 & 0.7 & 8,778 & 21,692 \\
Wildlife Refuge & 0.5 & $<0.1$ & $<1,254$ & 3,099 \\
& & & & & \\
Native American Lands & 0.1 & 0 & 0 & 0 \\
\hline
\end{tabular}




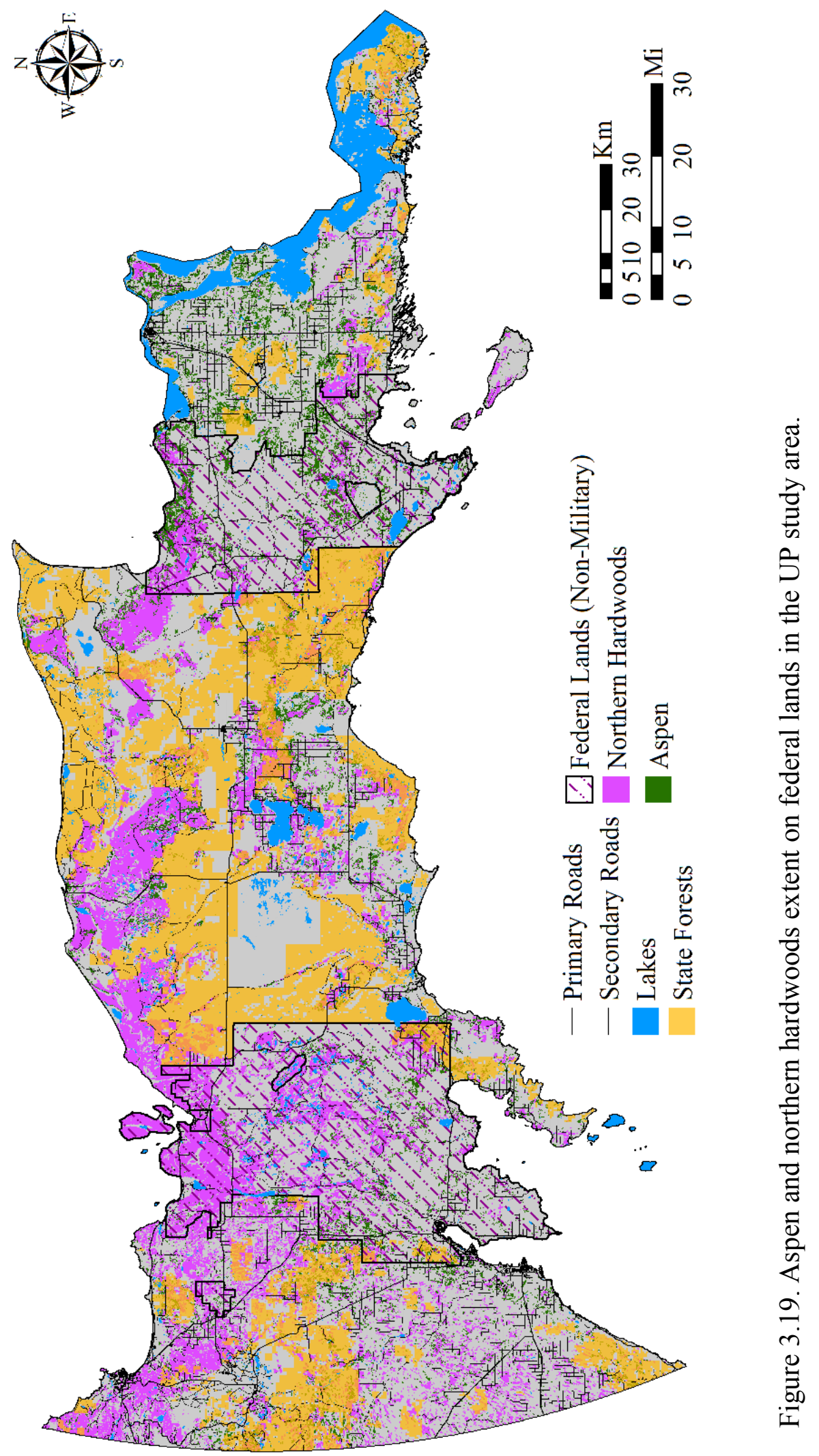




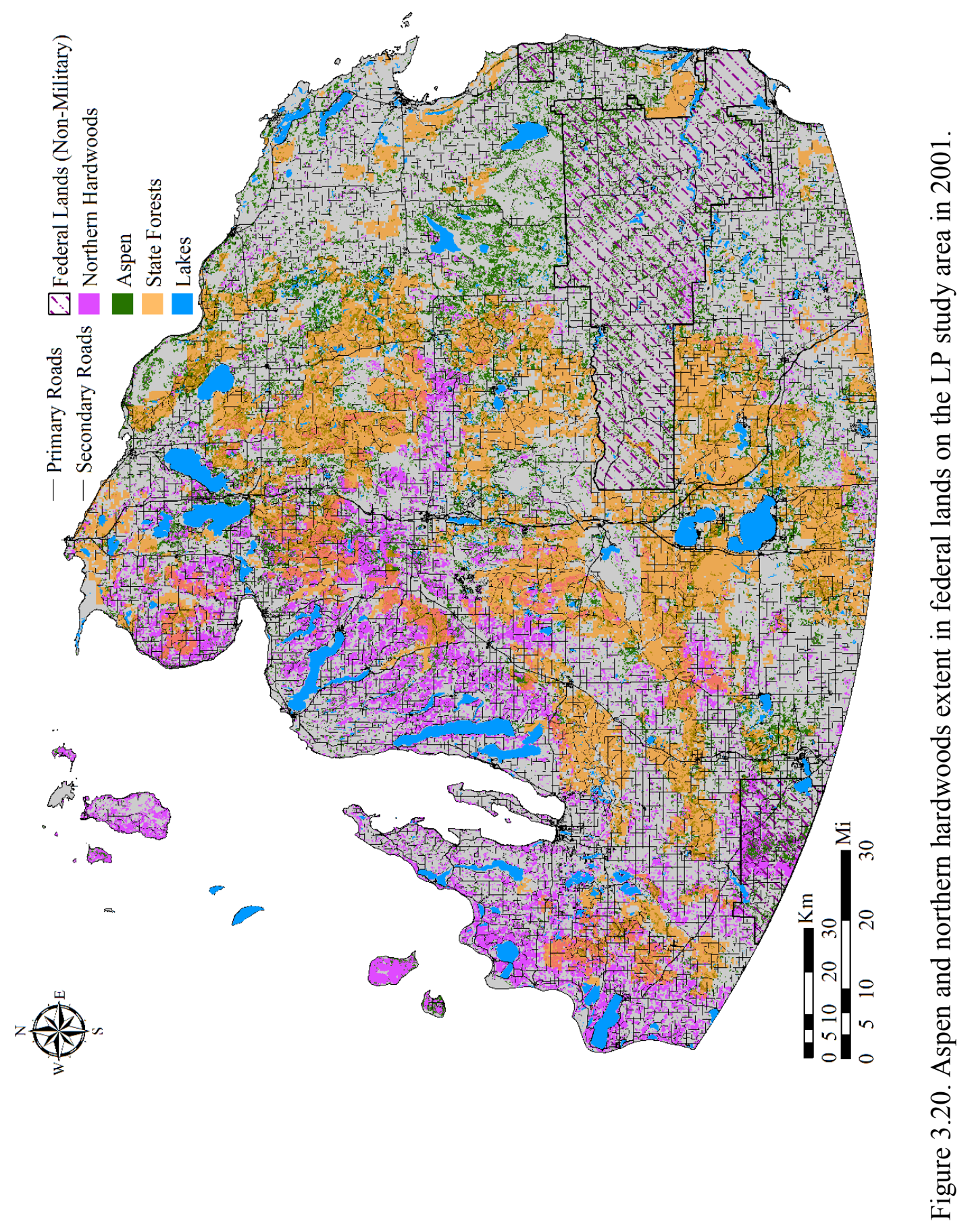


To identify potential aspen and northern hardwoods restoration sites in government ownership, boundaries of these areas were overlaid on the pre-European land cover. About 784,000 and 1,450,000 ha of the aspen and northern hardwoods forests were identified in the UP and LP, respectively. About $27 \%$ of the Upper Peninsula's aspen and northern hardwoods and 7\% of the LP's feedstock sources in 1800 were located within the federal lands. Also, $18 \%$ of the feedstock sources in the UP, and $17 \%$ in the LP are located within the state lands. A small proportion of aspen and northern hardwoods forests are located inside the wildlife refuge (about $0.5 \%$ ) and military installation lands (about 1.1\%) in the UP and LP. The results of this analysis suggest a $28 \%$ decrease in the aspen and northern hardwoods in the UP study area, and a 43\% decrease in the LP study area as compared with circa 1800 , which can potentially be restored for feedstock production. Figures 3.21 and 3.22 show the location of federal and state lands on the preEuropean map. 


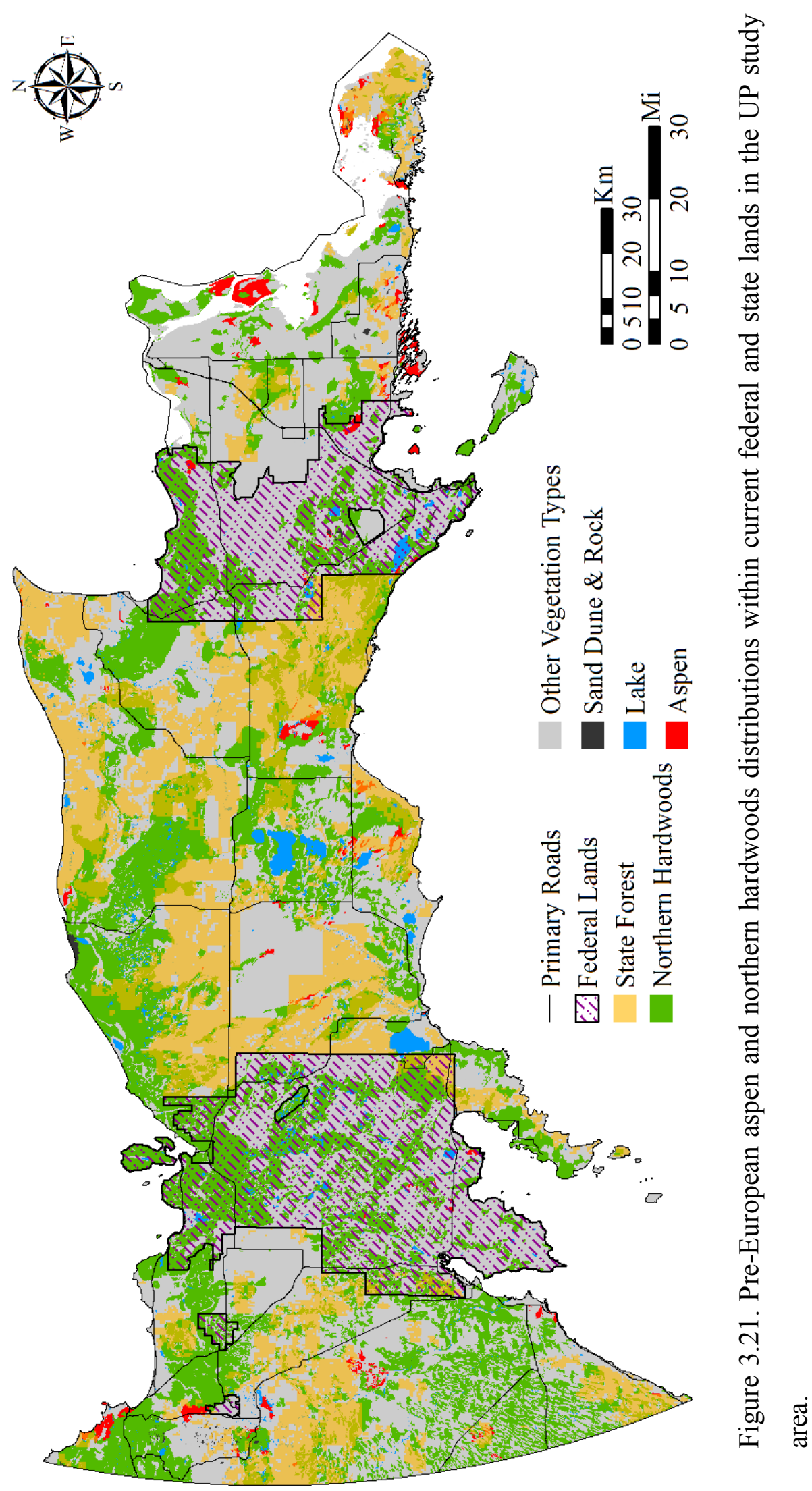




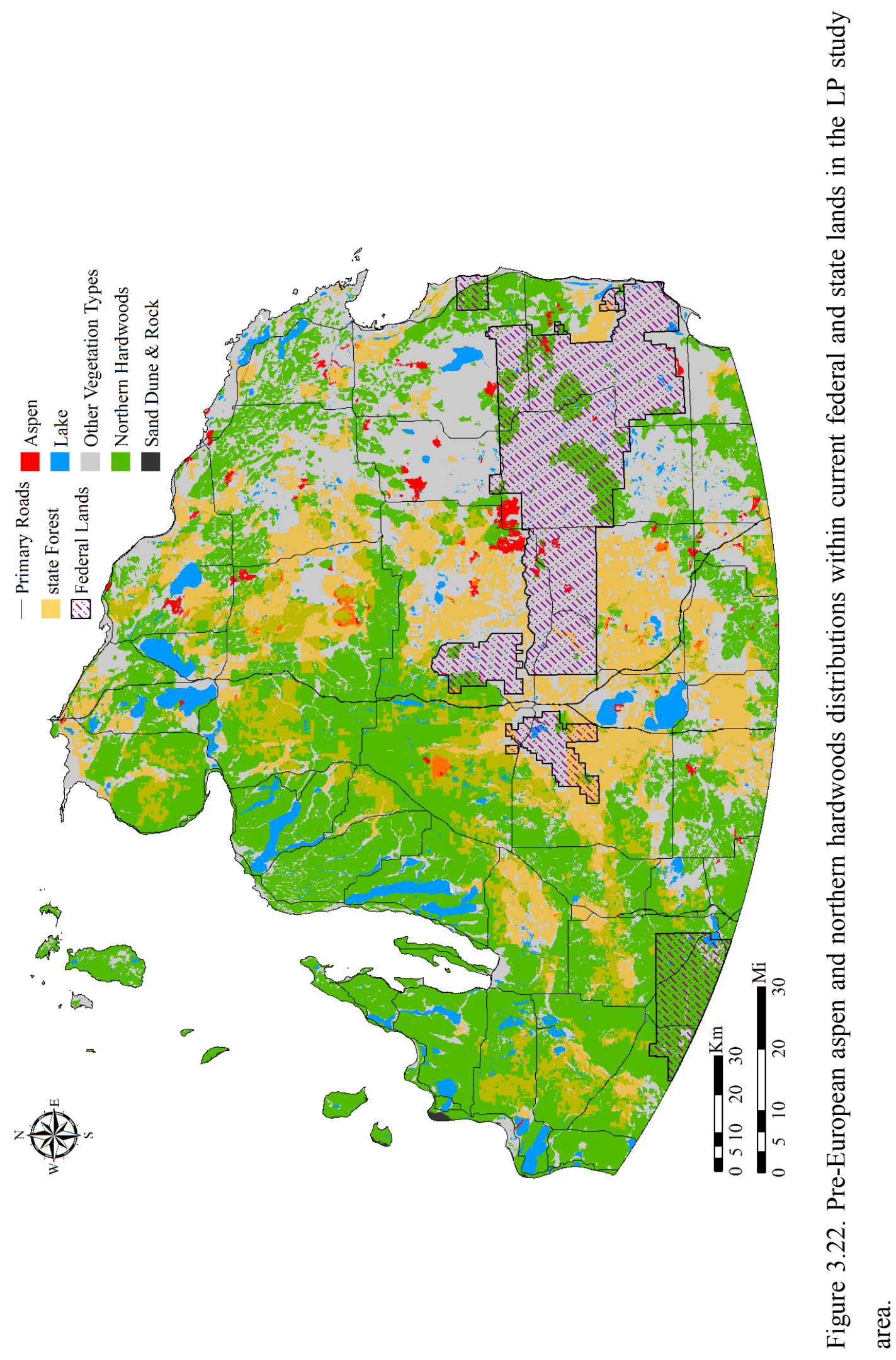




\subsection{Wetlands, hydric and non-hydric soils}

Other restrictions for land use in feedstock production are the wetland conservation and restoration programs. Part 303 of Michigan's wetland statute, Wetlands Protection, of the Natural Resources and Environmental Protection Act, 1994 PA 451, as amended, provides a legal definition for wetlands, i.e., "land characterized by the presence of water at a frequency and duration sufficient to support, and that under normal circumstances does support, wetland vegetation or aquatic life, and is commonly referred to as a bog, swamp, or marsh." This legal definition of wetlands applies to public and private lands regardless of zoning or ownership.

Furthermore, characterization of hydric and non-hydric soil types is potentially important for determining the type of feedstock plantation. More than half of the UP (53\%) and one third (37\%) of the LP study areas are wetlands. Despite the abundance of wetlands, they contain a small proportion of the aspen and northern hardwoods feedstock sources in the study area, i.e., $\sim 110,700$ ha $(273,545 \mathrm{ac})(9.5 \%)$ in the UP and $\sim 80,500$ ha $(198,919$ ac) $(11 \%)$ in the LP study area. Likewise, the amount of aspen and northern hardwoods forests in hydric soils is insignificant. About $87 \%$ of aspen and northern hardwoods in the UP and 94\% in the LP study areas is located in non-hydric soils (Figure 3.23 and 3.24). The feedstock sources in hydric and non-hydric soils are shown separately in Figure 3.25. 


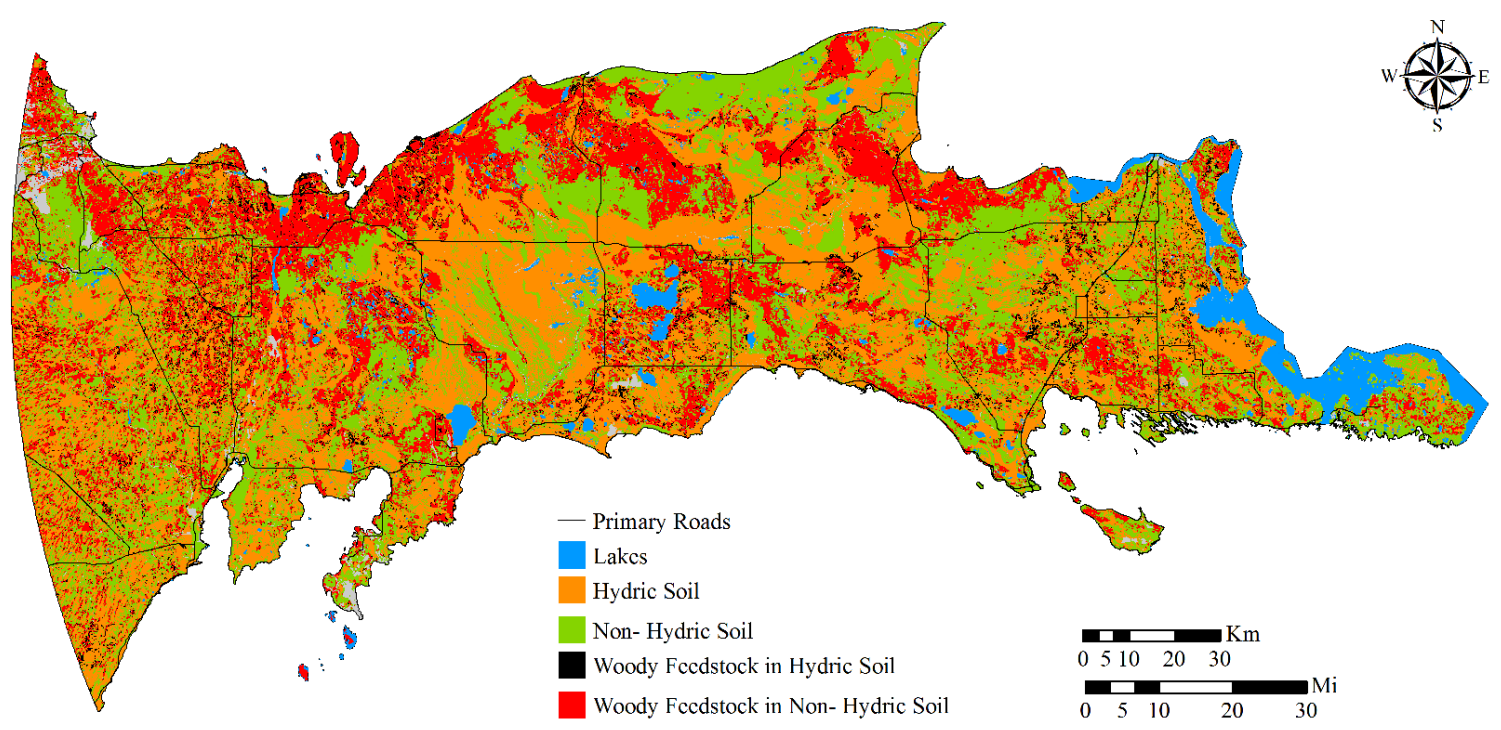

Figure 3.23. Aspen and northern hardwoods in hydric and non-hydric soil in the UP study area.

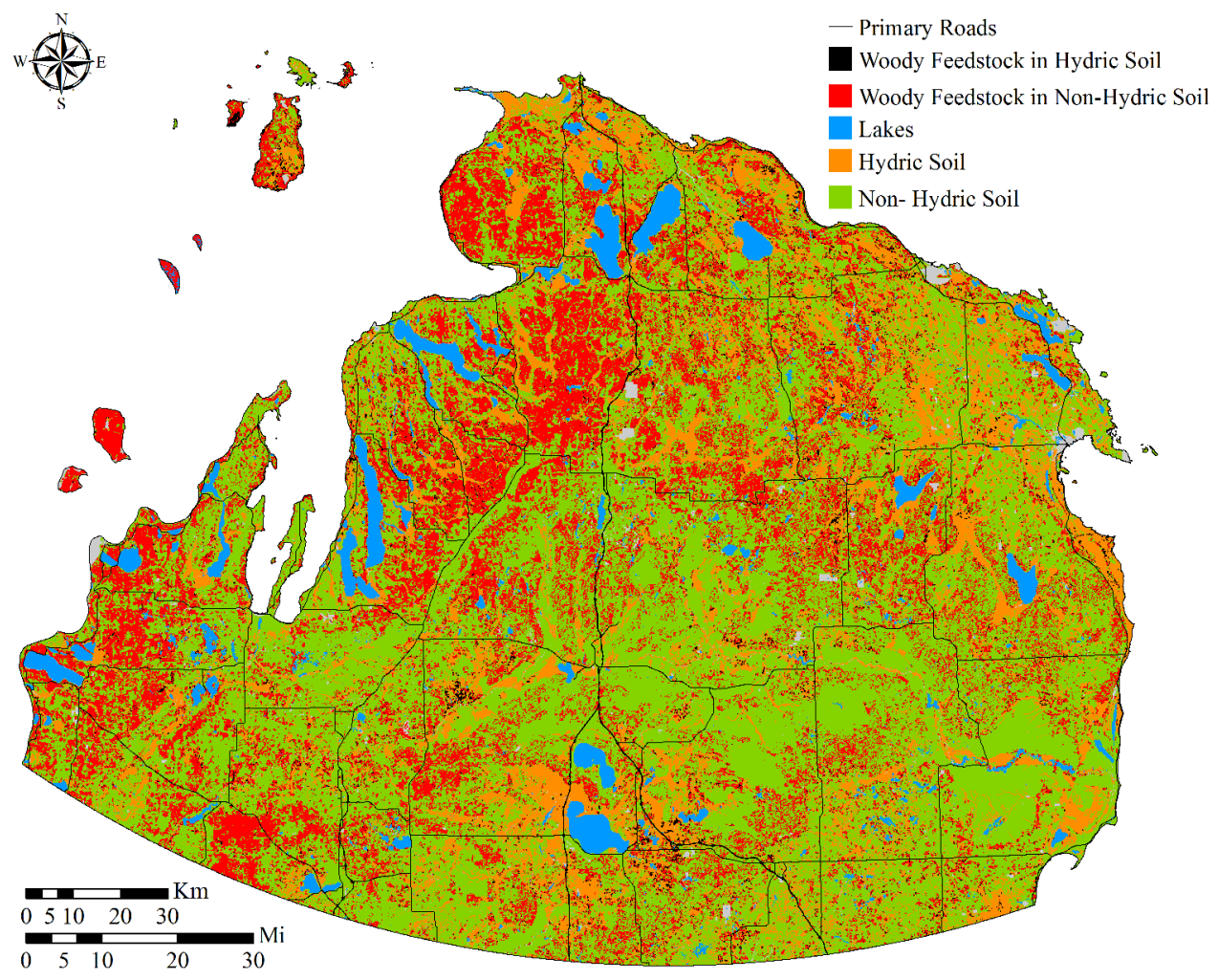

Figure 3.24. Aspen and northern hardwoods in hydric and non-hydric soil in the LP study area. 


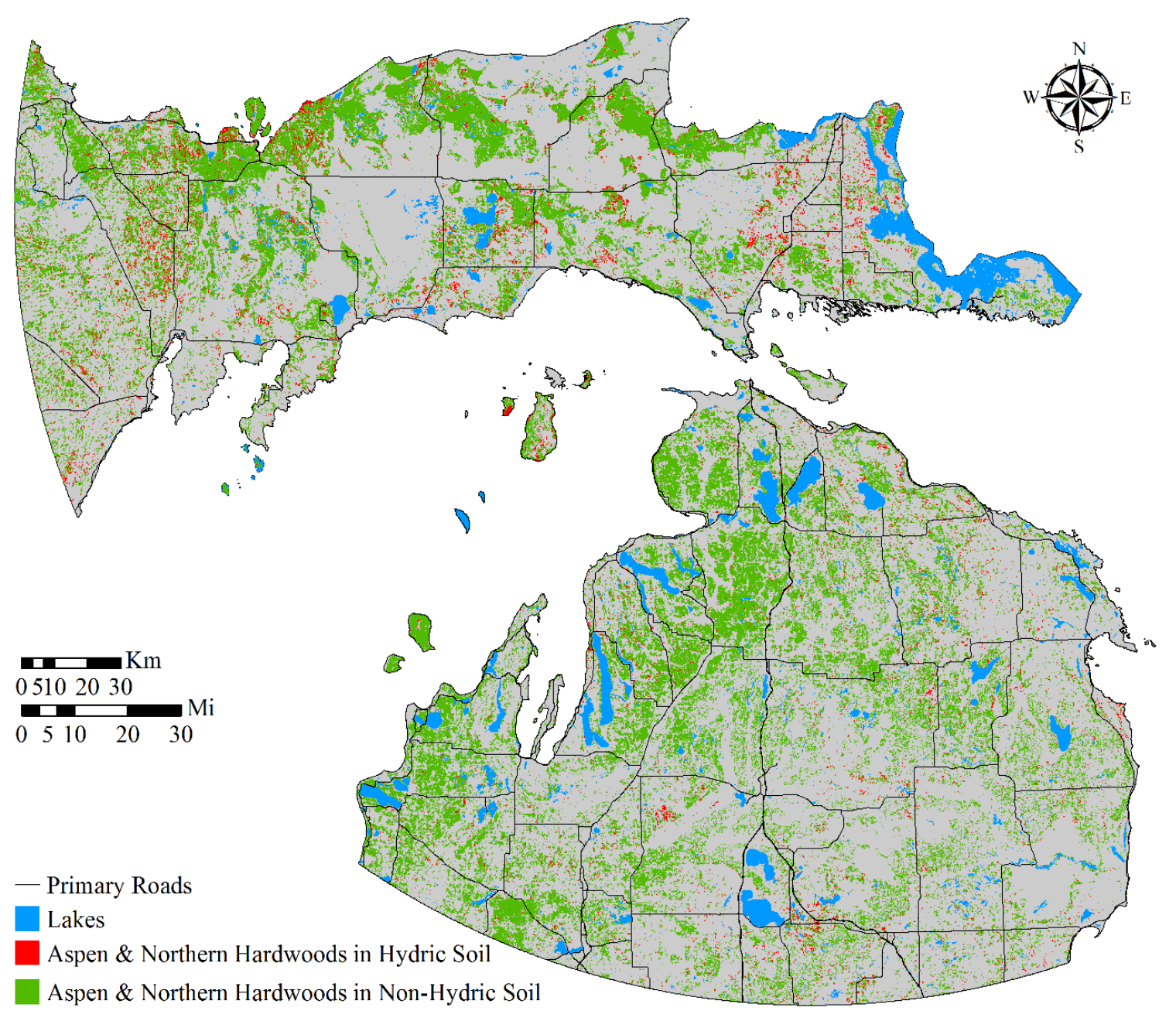

Figure 3.25. Aspen and northern hardwoods association in hydric and non-hydric soils in the study area.

\subsection{Hardwood Site Suitability}

Soil suitability for northern hardwoods plantation has been classified into four groups, i.e., good, fair, poor, and very poor. These ratings indicate the amount of management effort needed for successful establishment of intended elements of the 
wildlife habitat. A rating of good will require least management effort to provide satisfactory habitat conditions, whereas a rating of fair means that the desired habitat elements can be established in most places with some management effort. A rating of poor indicates that habitat establishment may be successful in most places subject to continuous and intensive management practices. Very poor soils are most unlikely to support elements of the desired habitat and unsatisfactory restoration effort can be expected despite intensive management. Most of the currently available aspen and northern hardwoods in the study area is are located in the good and fair soils (Figures 3.26 and 3.27). Likewise, the potential restoration areas, obtained from comparing preEuropean land cover and IFMAP land cover 2001, are mostly located in good and fair soil types as shown in Figures 3.28 and 3.29. This suggests that aspen and northern hardwoods restoration for woody feedstock production can be satisfactorily accomplished without intensive land management. 


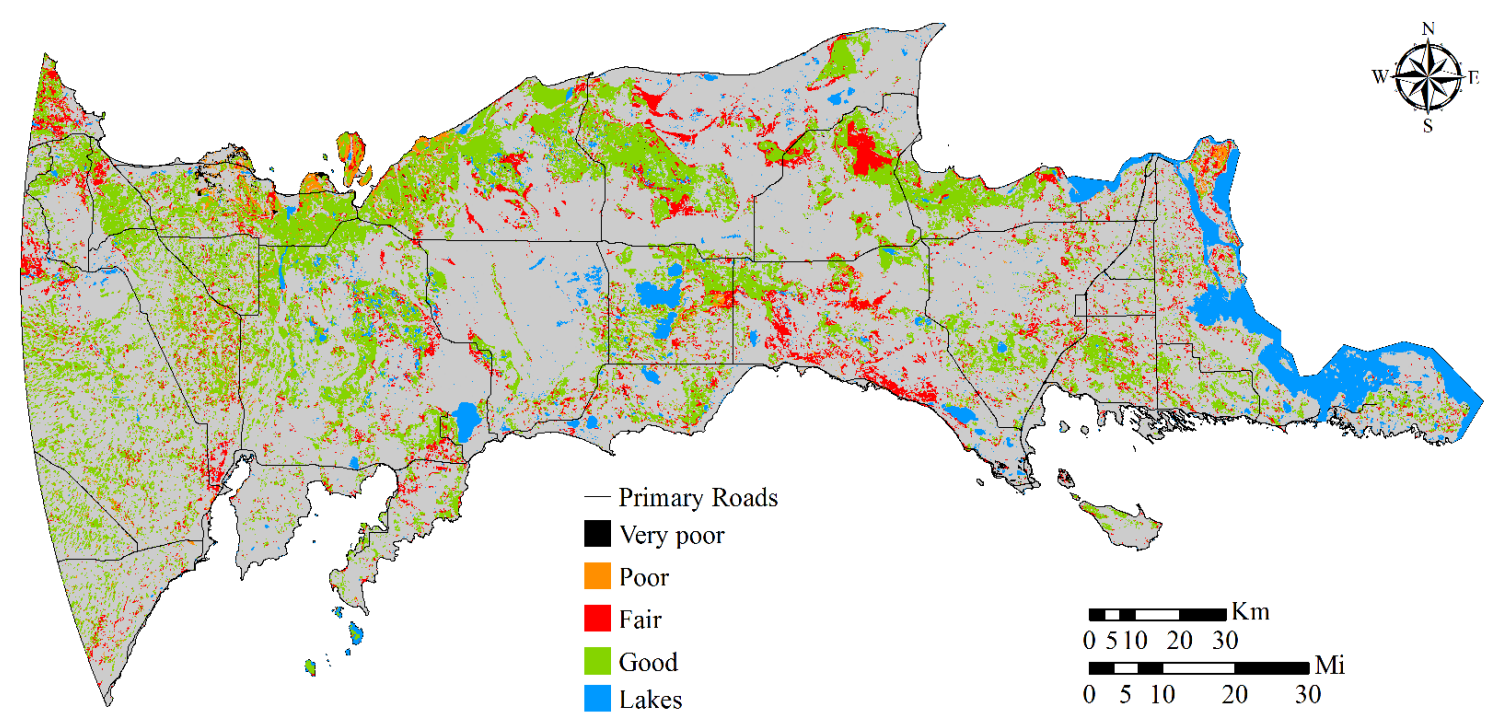

Figure 3.26. Aspen and northern hardwoods extent on different soil suitability classes for establishing these cover types in the UP study area.

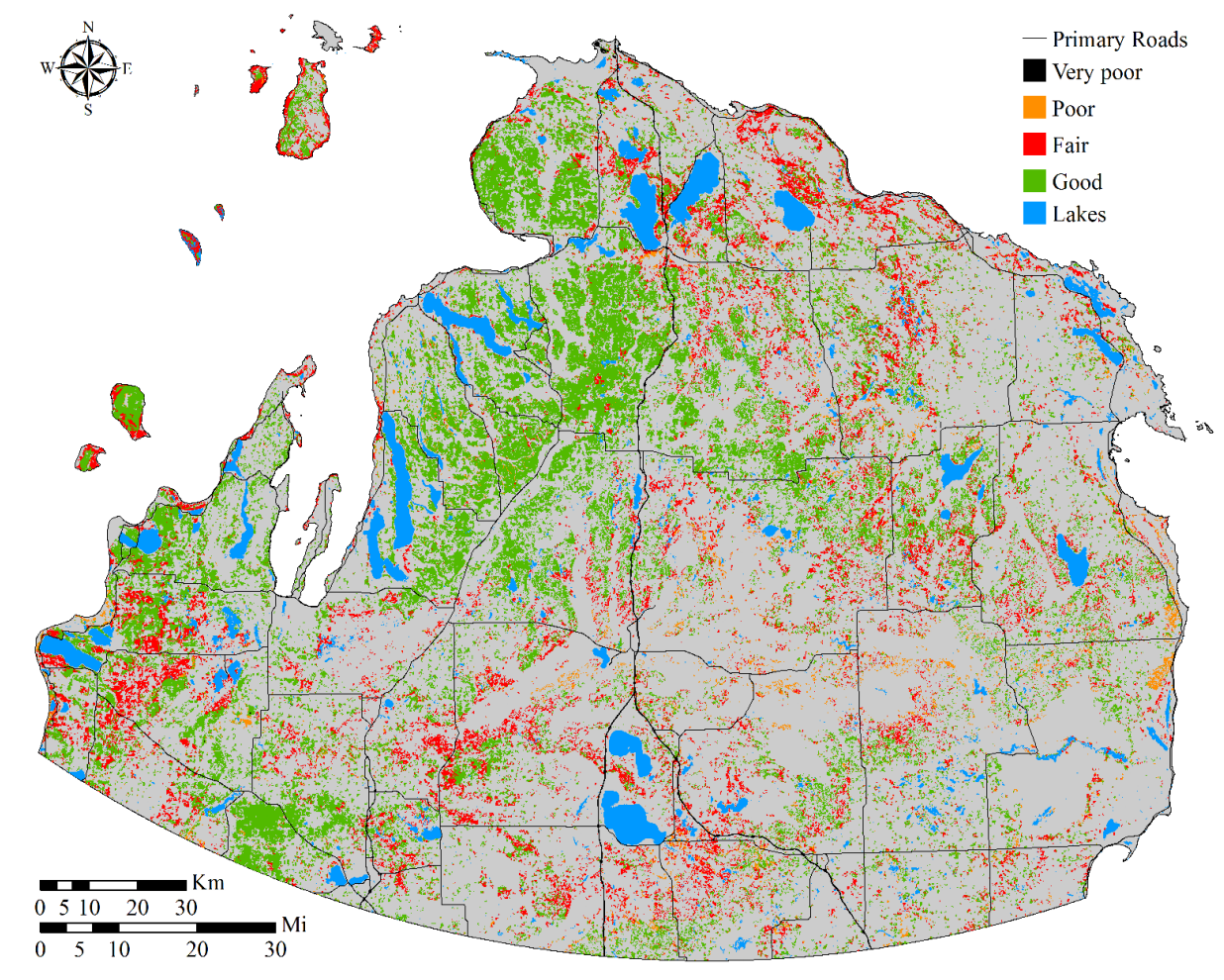

Figure 3.27. Aspen and northern hardwoods extent on different soil suitability classes for establishing these cover types in the LP study area. 


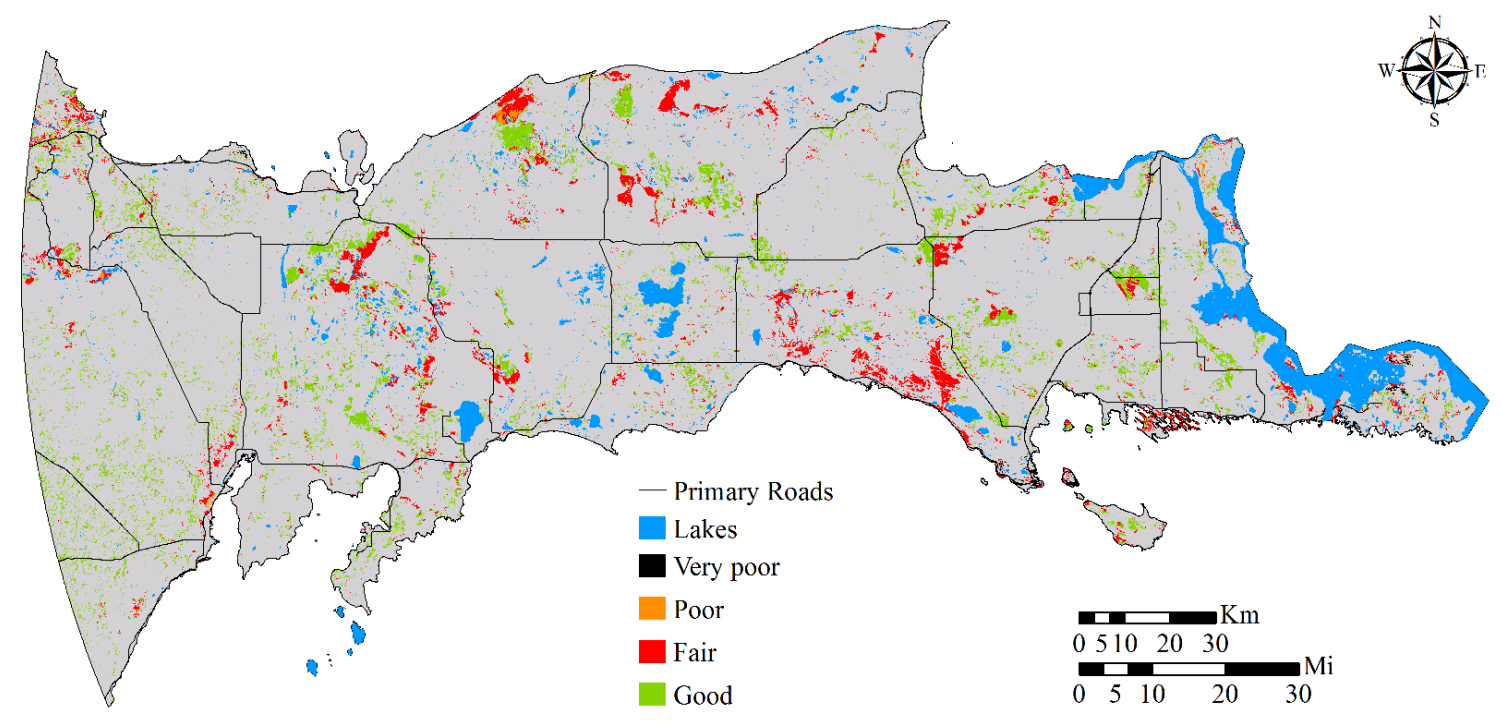

Figure 3.28. Potential restoration areas in the UP study area based on 1800s and 2001 data.

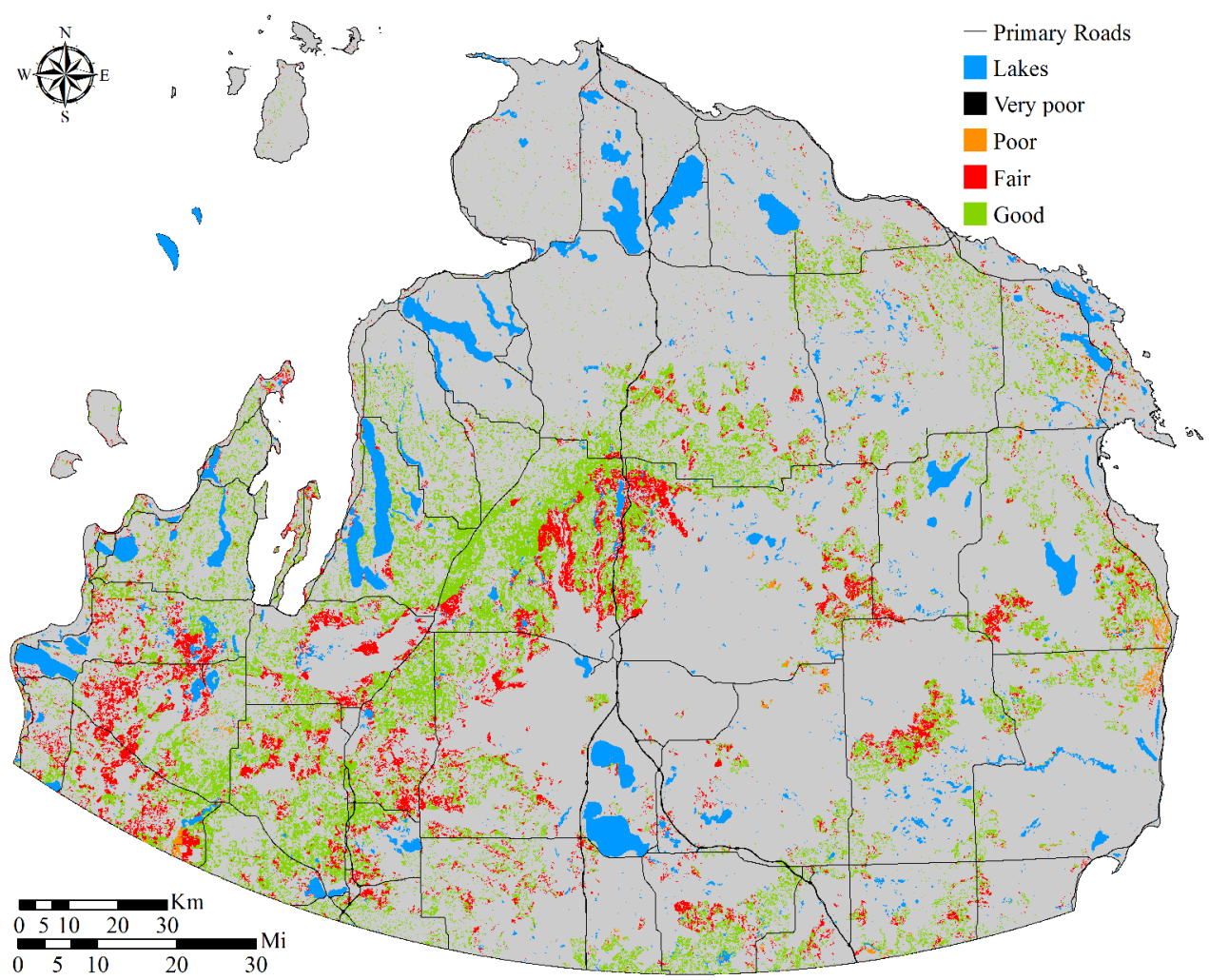

Figure 3.29. Potential restoration areas in the LP based on 1800s and 2001 data. 


\subsection{Proposing sites for woody feedstock source restoration}

Table 3.7 and figures 3.30 and 3.31 present the feedstock source restoration potential of the study area. These areas are recommended for aspen and northern hardwoods plantation as they are not located within national parks, wetlands, wildlife refuges, Indian lands, and federal military lands, agricultural, and urban areas. Furthermore, these recommended restoration areas are in close vicinity of the existing road network. The recommended sites in the UP study area are mostly located within 100 miles from the Kinross ethanol plant, within 0.25 mile of the primary and secondary roads. The majority of the recommended sites in the LP study area are located farther from Kinross, i.e., between $100-150$ miles of the Kinross ethanol plant, within the 0.25 mile of the primary and secondary roads. 
Table 3.7. Incremental aspen and northern hardwoods in the recommended restoration sites (ha) in the UP and LP study areas.

\begin{tabular}{ccccc}
\hline Miles & LP (ha) & LP (ac) & UP (ha) & UP (ac) \\
\hline 0.25 & 301,931 & 827,593 & 77,647 & 212,830 \\
0.50 & 93,338 & 255,840 & 35,340 & 96,867 \\
0.75 & 22,513 & 61,708 & 20,009 & 54,845 \\
1.00 & 9,020 & 24,724 & 13,111 & 35,937 \\
1.50 & 5,404 & 14,812 & 15,187 & 41,628 \\
2.00 & 2,094 & 5,740 & 7,291 & 19,985 \\
3.00 & 2,136 & 5,855 & 6,144 & 16,841 \\
4.00 & 199 & 545 & 963 & 2,640 \\
5.00 & 3 & 8 & 380 & 1,042 \\
\hline
\end{tabular}




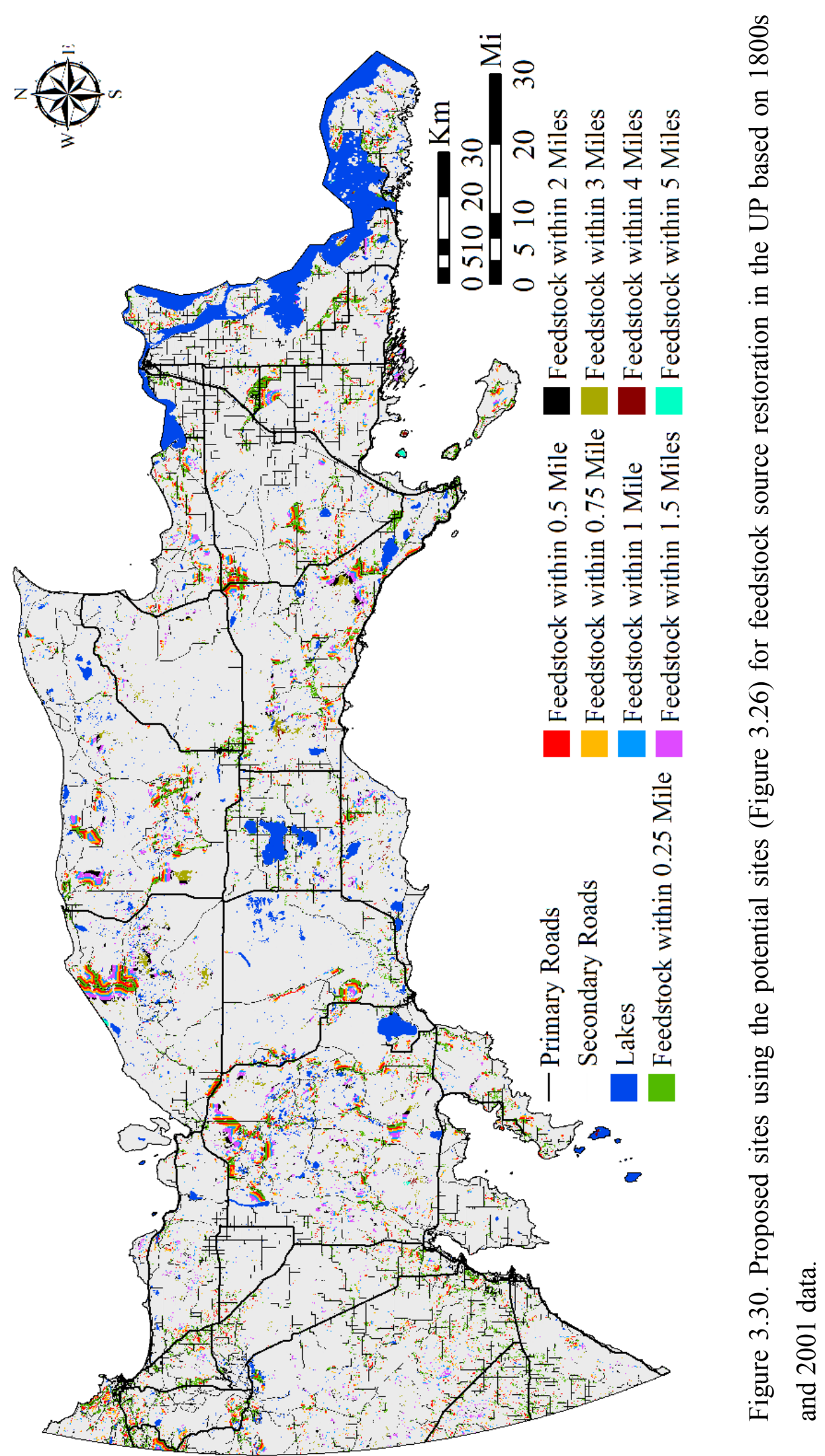




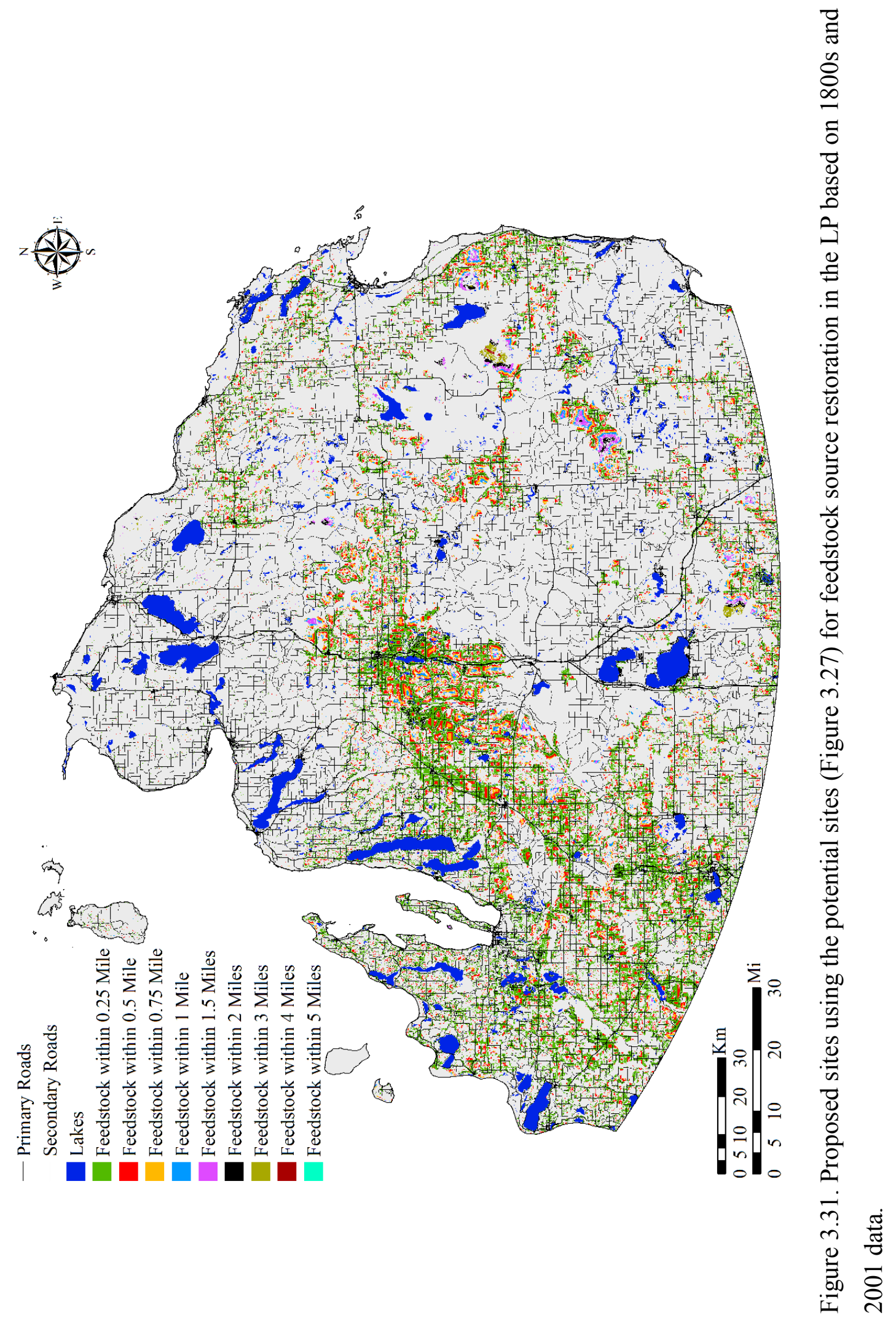




\subsection{Reference}

Leefers. L.A. and J.M. Vasievich. 2010. Timber Resources and Factors Affecting Timber Availability and Sustainability for Kinross, Michigan. Report prepared for the Feedstock Supply Chain Center of Energy Excellence. Kinross Project 2 Report, Version 2.0., East Lansing, MI: Michigan State University, Department of Forestry. 55 p.

U.S. Department of Agriculture, Natural Resources Conservation Service (USDANRCS), 2013. National soil survey handbook (NSSH), title 430-VI. Lincoln, Nebraska $<$ http://soils.usda.gov/technical/handbook/> (accessed on 1 July 2013). 


\section{Chapter 4- Conclusions}

Instability of production and price of oil, as well as environmental concerns such as anthropogenic climate change necessitate efforts to expand the global energy mix and finding sustainable energy sources. The need for expanding biofuel production is increasing as the world prepares to diversify the global energy mix to increase security and sustainability of energy production. The Americas produces a large share of the world's biofuel.

The state of Michigan, with its vast feedstock sources of northern hardwoods, hybrid poplar, and hybrid willow (Salix spp.) is an area where biofuel production can be expanded. However, extent of sufficient feedstock sources and the potential for long-term feedstock production need to be characterized before biofuel production initiatives such as Kinross ethanol production plant can be developed and operated.

Understanding the spatial distribution of the current feedstock sources, in terms of coverage area, accessibility for harvest when considering the transportation infrastructure and land ownerships, is important for long-term feedstock production in the area. This thesis provides the results of a geospatial analysis of aspen and northern hardwoods association extent, as well as the potential for restoring these woody feedstock sources to pre-European settlement condition in areas with convenient access to transportation infrastructure.

A GIS was developed to compile present day (circa 2001) and pre-European settlement (circ 1800s) land use/cover, soils, road infrastructure, and ownership data for 
33 counties located within 150 miles of the Kinross facility. The land use change between pre-European settlement and circa 2001 was characterized, and suitable areas for aspen and northern hardwoods association development were identified with respect to soil condition and land ownerships and land use/cover criteria.

The results suggest that a significant amount of northern hardwoods has been converted to other land use and cover types since European settlement, and the scattering of aspen stands has increased. Furthermore, a significant amount of woody biomass is available in close vicinity of the existing road network, which can be effectively used as feedstock for the Kinross ethanol production facility. Potential aspen and northern hardwoods forest restoration areas were identified in proximity to road networks, which can support future woody feedstock production. The insights from this work provide a basis for expanding woody feedstock sources in the study area. 
Appendix A.

County level aspen and northern hardwood distribution 
Table A-1. Aspen and northern hardwoods distribution for the counties within the study area.

\begin{tabular}{|c|c|c|c|}
\hline County & Feedstock & Hectares & Acres \\
\hline \multirow{3}{*}{ Alger } & ASP & 9,755 & 24,105 \\
\hline & NHW & 117,011 & 289,143 \\
\hline & Total & 126,766 & 313,248 \\
\hline \multirow{3}{*}{ Chippewa } & ASP & 50,755 & 125,420 \\
\hline & NHW & 41,515 & 102,585 \\
\hline & Total & 92,270 & 228,005 \\
\hline \multirow{3}{*}{ Delta } & ASP & 26,360 & 65,135 \\
\hline & NHW & 39,265 & 97,027 \\
\hline & Total & 65,625 & 162,162 \\
\hline \multirow{3}{*}{ Luce } & ASP & 14,435 & 35,665 \\
\hline & NHW & 49,690 & 122,785 \\
\hline & Total & 64,125 & 158,450 \\
\hline \multirow{3}{*}{ Mackinac } & ASP & 33,385 & 82,497 \\
\hline & NHW & 35,940 & 88,807 \\
\hline & Total & 69,325 & 171,304 \\
\hline \multirow{3}{*}{ Marquette } & ASP & 15,200 & 37,570 \\
\hline & NHW & 58,250 & 143,940 \\
\hline & Total & 73,450 & 181,510 \\
\hline \multirow{3}{*}{ Menominee } & ASP & 2,940 & 7,270 \\
\hline & NHW & 14,020 & 34,640 \\
\hline & Total & 16,020 & 41,910 \\
\hline \multirow{3}{*}{ Schoolcraft } & ASP & 14,571 & 36,010 \\
\hline & NHW & 40,960 & 101,220 \\
\hline & Total & 55,531 & 137,230 \\
\hline \multirow{3}{*}{ Alcona } & ASP & 31,326 & 77,410 \\
\hline & NHW & 2,920 & 7,220 \\
\hline & Total & 34,246 & 84,630 \\
\hline \multirow{3}{*}{ Alpena } & ASP & 16,500 & 40,775 \\
\hline & NHW & 2,795 & 6,910 \\
\hline & Total & 19,295 & 47,685 \\
\hline \multirow{3}{*}{ Antrim } & ASP & 8,335 & 20,600 \\
\hline & NHW & 40,720 & 100,625 \\
\hline & Total & 49,055 & 121,225 \\
\hline \multirow{3}{*}{ Arenac } & ASP & 1,033 & 2,555 \\
\hline & NHW & 927 & 2,293 \\
\hline & Total & 1,960 & 4,848 \\
\hline \multirow{3}{*}{ Charlevoix } & ASP & 4,955 & 12,240 \\
\hline & NHW & 32,840 & 81,155 \\
\hline & Total & 37,795 & 93,395 \\
\hline \multirow{3}{*}{ Benzie } & ASP & 6,725 & 16,620 \\
\hline & NHW & 37,875 & 93,595 \\
\hline & Total & 44,600 & 110,215 \\
\hline \multirow{3}{*}{ Cheboygan } & ASP & 36,230 & 89,520 \\
\hline & NHW & 21,670 & 53,555 \\
\hline & Total & 57,900 & 143,075 \\
\hline
\end{tabular}


Table A-1. Continued.

\begin{tabular}{|c|c|c|c|}
\hline County & Feedstock & Hectares & Acres \\
\hline \multirow{3}{*}{ Clare } & ASP & 3,845 & 9,500 \\
\hline & NHW & 1,835 & 4,540 \\
\hline & Total & 5,680 & 14,040 \\
\hline \multirow{3}{*}{ Crawford } & ASP & 13,860 & 34,250 \\
\hline & NHW & 4,820 & 11,912 \\
\hline & Total & 18,680 & 46,162 \\
\hline \multirow{3}{*}{ Emmet } & ASP & 13,695 & 33,840 \\
\hline & NHW & 35,260 & 87,125 \\
\hline & Total & 48,955 & 120,965 \\
\hline \multirow{3}{*}{ Gladwin } & ASP & 2,945 & 7,275 \\
\hline & NHW & 1,210 & 2,990 \\
\hline & Total & 4,155 & 10,265 \\
\hline \multirow{3}{*}{ Grand Traverse } & ASP & 4,495 & 11,110 \\
\hline & NHW & 14,405 & 35,595 \\
\hline & Total & 18,900 & 46,705 \\
\hline \multirow{3}{*}{ Iosco } & ASP & 9,265 & 22,895 \\
\hline & NHW & 2,755 & 6,815 \\
\hline & Total & 12,020 & 29,710 \\
\hline \multirow{3}{*}{ Kalkaska } & ASP & 13480 & 33310 \\
\hline & NHW & 22490 & 55575 \\
\hline & Total & 35,970 & 88,885 \\
\hline \multirow{3}{*}{ Leelanau } & ASP & 3,240 & 8,005 \\
\hline & NHW & 31,535 & 77,925 \\
\hline & Total & 34,775 & 85,930 \\
\hline \multirow{3}{*}{ Manistee } & ASP & 3,093 & 7,643 \\
\hline & NHW & 10,397 & 25,692 \\
\hline & Total & 13,490 & 33,335 \\
\hline \multirow{3}{*}{ Missaukee } & ASP & 16,660 & 41,162 \\
\hline & NHW & 13,640 & 33,708 \\
\hline & Total & 30,300 & 74,870 \\
\hline \multirow{3}{*}{ Montmorency } & ASP & 30,672 & 75,792 \\
\hline & NHW & 11,340 & 28,025 \\
\hline & Total & 42,012 & 103,817 \\
\hline \multirow{3}{*}{ Ogemaw } & ASP & 16,240 & 40,130 \\
\hline & NHW & 7,050 & 17,425 \\
\hline & Total & 23,290 & 57,555 \\
\hline \multirow{3}{*}{ Osceola } & ASP & 50 & 130 \\
\hline & NHW & 277 & 685 \\
\hline & Total & 327 & 815 \\
\hline \multirow{3}{*}{ Oscoda } & ASP & 18,659 & 46,107 \\
\hline & NHW & 2,295 & 5,672 \\
\hline & Total & 20,954 & 51,779 \\
\hline \multirow{3}{*}{ Otsego } & ASP & 18,537 & 45,806 \\
\hline & NHW & 20,449 & 50,530 \\
\hline & Total & 38,986 & 96,336 \\
\hline
\end{tabular}


Table A-1. Continued.

\begin{tabular}{|c|c|c|c|}
\hline County & Feedstock & Hectares & Acres \\
\hline \multirow{3}{*}{ Presque Isle } & ASP & 33,286 & 74,432 \\
\cline { 2 - 4 } & NHW & 4,566 & 11,138 \\
\cline { 2 - 4 } & Total & $\mathbf{3 7 , 8 5 2}$ & $\mathbf{8 5 , 5 7 0}$ \\
\hline \multirow{3}{*}{ Roscommon } & ASP & 22,707 & 56,111 \\
\cline { 2 - 4 } & NHW & 1,688 & 4,171 \\
\cline { 2 - 4 } & Total & $\mathbf{2 4 , 3 9 5}$ & $\mathbf{6 0 , 2 8 2}$ \\
\hline \multirow{3}{*}{ Wexford } & ASP & 18,609 & 45,984 \\
\cline { 2 - 4 } & NHW & 18,940 & 46,801 \\
\cline { 2 - 4 } & Total & $\mathbf{3 7 , 5 4 9}$ & $\mathbf{9 2 , 7 8 5}$ \\
\hline
\end{tabular}

